Portland State University

PDXScholar

12-9-1994

\title{
The Anabaptist Contributions to the Idea of Religious Liberty
}

Barbara Monette

Portland State University

Follow this and additional works at: https://pdxscholar.library.pdx.edu/open_access_etds

Part of the History Commons

Let us know how access to this document benefits you.

Recommended Citation

Monette, Barbara, "The Anabaptist Contributions to the Idea of Religious Liberty" (1994). Dissertations and Theses. Paper 5060.

https://doi.org/10.15760/etd.6936

This Thesis is brought to you for free and open access. It has been accepted for inclusion in Dissertations and Theses by an authorized administrator of PDXScholar. Please contact us if we can make this document more accessible: pdxscholar@pdx.edu. 


\section{THESIS APPROVAL}

The abstract and thesis of Barbara Monette for the Master of Arts in History were presented December 9, 1994, and accepted by the thesis committee and the department.

COMMITTEE APPROVALS:
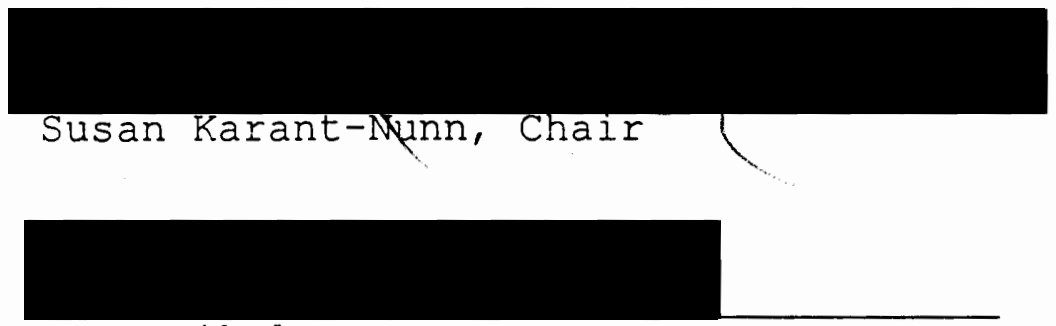

Ann Weikel

DEPARTMENT APPROVAL:

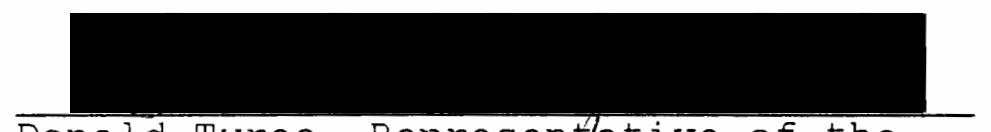

Donald Tyree, Representative of the Office of Graduate Studies

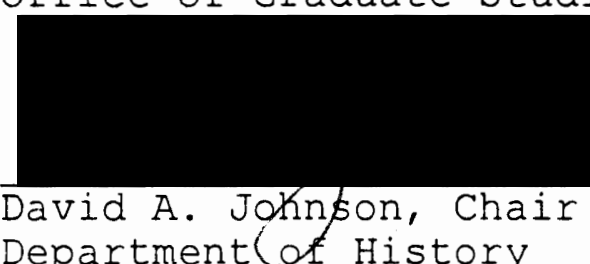

Department (af History

ACCEPTED FOR PORTLAND STATE UNIVERSITY BY THE LIBRARY

by

on

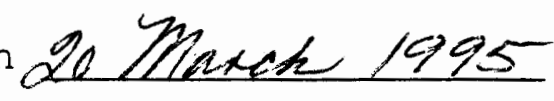




\section{ABSTRACT}

An abstract of the thesis of Barbara Monette for the Master of Arts in History presented December 9, 1994.

Title: The Anabaptist Contributions to the Idea of Religious Liberty.

The relationship between ideas and history is important in order to understand the past and the present. The idea of religious liberty and the realization of that ideal in sixteenth-century Europe by the Anabaptists in Switzerland and South Germany in the 1520 s was considered to be revolutionary in a society characterized by the union of church and state. The main impetus of the idea of religious liberty for the Anabaptists was the application of the New Testament standard of the Christian church, which was an independent congregation of believers marked only by adult baptism.

The purpose of the present study is to demonstrate the contributions of the Swiss Anabaptists to the idea of religious liberty by looking at the ministries and activities of three major leaders of the early swiss movement: Conrad Grebel, Michael Sattler, and Balthasar Hubmaier. This thesis takes up the modern form of 
religious liberty as analyzed by twentieth-century authorities, as a framework for better understanding the contributions of the Anabaptists. My research then explores the estabiishment of the first Anabaptist church in history, the Zollikon church outside of Zurich, and examines its organization membership, motives, and strategies for evangelizing Switzerland. In all areas influenced by the Anabaptists, there was considerable acceptance of their doctrine of a separated church. Their teaching on liberty of conscience also influenced people in towns such as Zollikon and Waldshut. Possible historical links between the Anabaptist doctrines and establishment of later Baptist denominations are shown. 
THE ANABAPTIST CONTRIBUTIONS TO

THE IDEA OF RELIGIOUS IIBERTY

by

BARBARA MONETTE

A thesis submitted in partial fulfillment of the requirements for the degree of

\author{
MASTER OF ARTS \\ in \\ HISTORY
}

Portland state University

1995 
The Anabaptists of the sixteenth and seventeenth centuries were among the most important contributors to the idea and practice of religious liberty. As pioneers of this ideal in the early modern period of European history, they brought about the reality of a continuous voluntary and independent church made up of individual Christian believers. The purpose of this thesis is to present the contributions of the Anabaptists to the modern idea of religious liberty by looking at the historical contributions of the earliest recognized Anabaptist movement, the Swiss Brethren and their founder Conrad Grebel. I shall also look at the writings and Iives of two other major leaders of the early period, Michael Sattler and Balthasar Hubmaier. I shall examine the practices that demonstrate the application of their ideas of the free Christian Church and its relationship to religious liberty, freedom of conscience, and separation of church and state. The purpose of this thesis, then, is to clarify the place of the Anabaptists in the formation of our heritage of religious liberty and to alert the present generation to the importance of preserving that heritage.

In the introduction, I shall define my terms, and outline the historical background pertaining to events 
and the ideas, groups, and persons who practiced or wrote about aspects of religious liberty, liberty of conscience, and their close interrelationship to the separation of church and state, before the emergence of the Anabaptists in the sixteenth century. This will not be an exhaustive treatment of the topic of separation of church and state. Where religious liberty was the primary demand or practice of a group, the idea of separation of church and state will be shown. In the case of the Anabaptists, religious liberty and complete separation of church and state were simultaneous, except in the view of Hubmaier. That is, their ideas and practices concerning the church as a free entity made up of believers only, independent of any established church and of the state itself, was the only acceptable form of religious liberty. This thesis will make a case for the Anabaptists' having contributed to the idea of religious liberty. Some of the ways in which this was manifested do not lend themselves to scientific historical analysis because ideas are first conceptual before they are implemented. This thesis is not an analysis of the development of religious liberty in the sixteenth century, or after. Nor does it deal with religious 
liberty within the broader context of the idea of toleration.

I.

The term Anabaptist means re-baptizer. This term was given to them by their enemies who saw them as a threat to the unity of church and society because of their denial of infant baptism. This practice was interrelated with the idea of the unity of society and the state, since both Catholic and Protestant reformers in the Reformation era practiced infant baptism, though for different reasons. The Anabaptists believed infant baptism to be wrong and non-scriptural. They insisted that baptism was only the outward symbol of inner faith and an act of obedience to Christ, not a predisposition to faith. For that reason they initiated believer's baptism as the mark of their faith. Since infants were incapable of faith and obedience, only adults could be baptized. Though the Anabaptists received their name because of their views on baptism, they were seen as a threat to society also because of their views of the church.

Anabaptism was a complex movement and included a variety of groups. Some groups in northern Germany were very militant and called for the immediate establishment 
of the kingdom of God on earth; some attempted to do so, such as Thomas Müntzer in Frankenhausen in 1525. Thomas Muntzer was not an Anabaptist in the strict sense of the term because he did not advocate adult baptism nor preach against infant baptism. His view of the church as consisting of believers only was the same as most Anabaptists, however. His method for establishing a believers church was by force, therefore opposed by the majority of Anabaptists. Others were peaceful and nonresisting, willing to suffer persecution or martyrdom for their faith. The type of Anabaptist on which this thesis will focus is what is generally known as the Church type or Convenantal or Biblical Anabaptists. They are known as Biblical Anabaptists because of their focus on the Bible and their efforts to apply it to their lives, especially their interpretation of scriptural discipleship and the church. Scholars such as Franklin Littell believe that Biblical Anabaptists made up the majority of peaceful Anabaptists, and it is this type that survived into the seventeenth century. They are also the type of Anabaptist that contributed the most to the idea of religious liberty.

The Reformation of the sixteenth century was begun by Martin Luther in 1517 in Germany (as a result of his 
nailing of the 95 Theses against Indulgences to the church door in Wittenberg) called into question the authority of the pope as head of the church and questioned the practices and rituals of the Roman Catholic church. Luther did this as a result of his opposition to the practice of indulgences, which was the paying of money to priests for the forgiveness of sins. He had examined the teachings of the New Testament and believed that it taught the forgiveness of sins came from repentance of the believer and his calling upon God's mercy. This the believer did as a result of faith alone in Christ alone without benefit of works. Hence, indulgences were a false teaching of the Roman Church. The Reformation began the greatest upheaval and revolution in the history of European Christendom. Much had prepared the way for the Reformation, such as the revival of classical learning, new translations of the Bible into vernacular languages, and pre-Reformation criticism of the church's wealth, doctrine, and abuses of authority. Luther believed that the final arbiter of all truth was the Bible and that the church was under the Scripture, not over it. Therefore, the pope and church were not teaching the Christianity of the Apostles, but a combination of the rituals and doctrines of classical 
philosophers, medieval scholastics and Germanic pagans. Thus, the Protestant movement began.

Luther's central theology was "justification by faith alone." One did not need the church or good works to attain salvation, but only faith in Christ alone. All true Christians were priests and saints with direct access to God. The visible church consisted mainly of true saints who had faith alone in Christ, but it also included the whole community, even those without faith.

The Swiss Reformer Huldrych Zwingli became the leader of the Reformation in Zurich, Switzerland, in the early 1520s. He was a humanist scholar and a Swiss patriot who, began to preach what would become Protestant doctrines from the Bible in Zurich. Zwingli agreed with Luther in most areas of theology and shared his view of the church. Zwingli's view of the relation between church and state was similar to Luther's, but it went further in making church leaders part of the city government as magistrates or councillors. Zwingli believed the church to be a congregation of all who truly believed in Christ -- its members known only to God (invisible church) -- and also the local community of worshippers (visible church). Young humanists and radicals under Zwingli's influence in Zurich, such as 
Conrad Grebel, thought Zwingli did not go far enough in his reform, especially regarding the Christian church. This resulted in the founding of the first Anabaptist group, known as the Swiss Brethren. The Brethren separated themselves from the state and community in 1525. Thus began the Anabaptist movement, which spread from Switzerland into Germany, eastern and central Europe, the Netherlands, and England. Their congregations were voluntary or gathered "churches" made up of true believers only, which differed from the Zwinglian view of the visible church's including within it both true and nominal worshippers. For Zwingli, as for Luther, there was no way of separating the true from the false Christians. For the Anabaptists, the visible Church, like the invisible Church, could be made up of true Christians only, and the new distinction was that they could be tested for correct belief and known by the moral uprightness of their lives. Their church was one of true believers only in contrast to Zwingli who believed the church on earth contained believers and unbelievers, wheat and tares, side by side. ${ }^{1}$ Their view of the church lay in a different view of Christian history. Their action of separating themselves from the

G. R. Potter, Zwingli (Cambridge: Cambridge University Press, 1976), p. 175 . 
state and community brought about the greatest challenge Zwingli and the Zurich Reformation would face.

The Anabaptist view of the church was central to their ideology. They compared themselves to Christians in the New Testament. For them, the true church was outside of any church that was united with the state. They saw the sixteenth-century reform as incomplete because it continued that ill-advised accommodation between Christianity and the state that begun under the Emperor Constantine in 313 A.D. The Church's "fall" had been complete, and a "restoration" of the true Church on the basis of New Testament principles was an urgent necessity. It went beyond biblicalism to a new or "restored" sociology. According to Franklin Littell, it was an outlook that could be described as primitivism. Their goal was to "restore" the church of the New Testament. Regardless of type of group or method of restoring the true Church, they desired to return to the uncorrupted church of the Apostles. "The single thread running through the Left wing was this dream of the early church. This is the thread which ties together the Spiritualists, Swiss Brethren, and Polish Brethren, Schwenckfelders, and Hutterites, Mennonites, and the 
followers of Sebastian Franck, and Adam Pastor." 2 For them, the church was not only free from secular or religious coercion, but it was made up of laymen who were accountable to each other with only the Bible and the Holy spirit as their guides. They were self-governing entities, setting their own standards, and choosing their own leaders. This notion was revolutionary in the sixteenth century. "The rise of the free churches, the development of the type of church life characteristic of America, the emergence of a new understanding of the vocation of the laity even within the old-style continental Protestantism; all of these movements are set in a new context." 3 It is possible to think of the Anabaptists, and particularly the convenantal Anabaptists, as not just radical Protestants but as a unique entity attempting to restore or establish a church on the basis of apostolic principles. From the modern standpoint on religious liberty, they contributed to the ideas of freedom of conscience and the separation of church and state.

After Constantine's edict of 313 A.D., which made Christianity legal in the declining Roman Empire, the

\footnotetext{
${ }^{2}$ Franklin H. Littell, The Origins of Sectarian Protestantism (New York: Macmillan Company, 1964), p. 47.

${ }^{3}$ Littell, origins, p. 79.
} 
Christian Church was gradually organized under Roman law, culture, and ideas. By the early Middle Ages, it had departed radically from its apostolic character and early Christian doctrines. Classical and pagan, as well as secular, political ideas and structures had turned it into a powerful hierarchy headed by the Pope. The church became the chief persecutor of all who did not conform to its doctrines and laws. It became totally united to the state and formed a united "Christendom" in which all subjects, except the few Jews, were nominally Christian. To be outside of this unity was heresy.

Heresies were forbidden by "divine and imperial law." Imperial authority in spiritual matters was mingled with earlier concepts of more-than-human standing of the sovereign. Thus Theodosius the Great in 380 pressed his subjects to conform to Catholic Christianity. By 407 heresy was made a public crime. The codes of Theodosius and Justianian were to appeal to medieval and early modern states into the Reformation. They entered into the Canon Law and formed the basis of the "Catholic State."

One of the bases for intolerance and coercion was the writings of St. Augustine, which were used even in the Counter-Reformation and which explain some of Luther's attitudes toward religious liberty during the Protestant Reformation. "The influence of st. Augustine was thrown toward compulsion. Fervent for freedom to the orthodox,

${ }^{4} \mathrm{M}$. Searle Bates, Religious Liberty: An Inquiry (New York: Harper and Brothers, 1945), p. 135 . 
he later called upon civil power against the dissident Donatists and repudiated the principle of liberty of conscience." 5 Though Augustine meant to be benevolent and protective, his thought was later used as a pretext for persecution. A. J. Carlyle writes, "The medieval Church was intolerant; this means that in the course of these centuries the Church ceased to be the protector of spiritual liberty of the individual and rather became its most formidable enemy." 6

As to those formidable men who stood for religious liberty and separation of church and state in the later Middle Ages, none was as influential as Marsilius of Padua who wrote the famous Defensor Pacis. The Defensor was completed in June 1324 after Marsilius had finished his studies in natural law at Padua and Paris. "Marcilius asserted that divine or religious law can have no other judge than Christ, with sanction only in the next world. Scripture can be employed for teaching, argument, and correction, never for compulsion or punishment." Though Marsilius contributed to general ideas concerning religious liberty, for the most part these ideas centered in the relationship of church and

\footnotetext{
${ }^{5}$ Bates, Religious Liberty, p. 138.

${ }^{6}$ Alexander J. Carlyle, The Christian Church and Liberty (London: $J$. Clarke, 1924), p. 96.

${ }^{7}$ Gewirth, Alan, ed., The Defensor pacis - Marsilius of Padua, 2

vols. (New York: Columbia University Press, 1956), vol. 1, p. 32.
} 
state. Marsilius was writing for the purpose of opposing papal and ecclesiastical authority. The papal "plenitude of power" deprived. the people who made up the state of their lawful rights. ${ }^{8}$

Joseph Lecler has observed that, although Marsilius promoted church-state differentiation into separate spheres, he gave nearly all authority over religious matters, especially those dealing with heresy, to the prince. He left the punishment of heresy in the hands of the state and therefore did not promote liberty of conscience in the sense of liberty or toleration. "The prince's authority alone has the right to pronounce a coercive judgment upon heretics and upon all those who deserve to be curbed by one punishment or another, the right to punish them in their person or their property, the right to enforce the application of such a judgment." 9

Nevertheless, Marsilius is revered as an early expositor of the idea that the temporal and spiritual spheres are separate and have different purposes. He does indeed anticipate modern thinking in his views of the "people as legislator."10 "For Marsilius, political

\footnotetext{
${ }^{8}$ Gewirth, Defensor, p. 32.

'Gewirth, Defensor, III vol. 2, 30; p. 603, in Joseph Lecler, S. J., Toleration and The Reformation, 2 vols. (New York: Association Press, 19601, vol. I, P. 92.

Gewirth, Defensor, vol. II, p. 169.
} 
freedom consists in self-government, in the sense that the laws under which men live derive from their own wills or consent."11

Regarding the church and what it is in relation to the individual, Marsilius describes the church not as the clergy or priesthood alone, but as "the whole body of the faithful, who believe in and invoke the name of Christ."12 Marsilius anticipated Luther's doctrine of the priesthood of all believers by placing the individual in direct relation to God.

He [Marsilius] threatens the hierarchic structure; he weakens the continuum between priesthood and God, reverses the superiority of clergy over laymen, and equalizes priests, bishops, and pope in that respect in which their authority had been considered essentially unequal. This revolution is accomplished by the different interpretations which he places upon the definition of the church. The phrase "of the faithful" no longer means that the laity are the subjects of a ruling hierarchy. It means not only that the church exists for all the faithful, but that the church is controlled by all the faithful, not merely by clergy or pope. ${ }^{13}$

In this, it is obvious that in Marsilius' view, both state and church will be controlled by their respective members.14 on the church and the individual Christians, Marsilius states,

\footnotetext{
11 Gewirth, Defensor, vol. II, p. 230.

12 Gewirth, Defensor, vol. II, p. 260.

${ }^{13}$ Gewirth, Defensor, vol. I, pp. 262-263.

${ }^{14}$ Gewirth, Defensor, vol. I, p. 264.
} 
So, then, it was the view of Paul and of Augustine that the church or all the Christian faithful must be subject to secular rulers, especially faithful ones, must obey those of their commands which are not contrary to the law of eternal salvation. But if the Apostle had meant that bishops or priests must rule and have coercive judgment over men's property or persons, he would have said to Timothy, whom he had made a bishop, "I exhort ... for all kings and bishops, that are in authority."15

Coercive power does not belong to any priest or bishop and Christians are exhorted to pray for secular rulers in order "that we may lead a quiet and peaceful life, free from persecution; that is, undisturbed."16 Concerning heretics Marsilius says, "The pastor or priest must teach them and exhort them in the present life, must censure and rebuke the sinner and frighten him by a judgment or prediction of future glory or eternal damnation; but he must not coerce."17

From the twelfth century on, the problem of the erring conscience was a central issue and was discussed by the scholastic theologians. "How does one treat the case of a conscience labouring under a wrong conviction? Is it a sin to follow such a conscience? Is it a sin to go against one's conscience?" The problem of the erroneous conscience was dealt with by Abelard in his moral treatise scito teipsum. ${ }^{18}$ In this treatise, he

\footnotetext{
${ }^{15}$ Gewirth, Defensor, vol. II, p. 137.

${ }^{16}$ Gewirth, Defensor, vol. II, p. 136.

${ }^{17}$ Gewirth, Defensor, vol. II, p. 174-5.

${ }^{18}$ Lecler, Toleration, p. 93.
} 
deals with intention and internal consent and concludes that the bad will alone, and not the action, constitute sin. ${ }^{19}$ The intention alone qualifies actions as good or bad.

The Waldensian movement, which began in France in the 1100 s as a result of the lay preaching of Peter Waldo, spread throughout Germany, Switzerland, Italy, and Austria. The later centuries found the Waldensians numerous in Northern Italy and Germany, and in 1488 Pope Innocent VIII called a crusade against them. They dared to operate as a free church, outside the institutional church, choosing their own pastors, preaching the Gospel on street corners, and reading the scriptures in the vernacular.

Thousands fell victim to the Dominican Inquisition, while in 1488 Pope Innocent VIII organized a crusade against the Waldenses in Dauphine and Savoy, in which an army of eighteen thousand men invaded the valleys, ruthlessly putting to the sword, men, women, and children. The manner in which these brethren endured in the faith has ever remained an inspiring symbol of the great sacrifices God's free men were ever ready to make in their struggle for a free Church. 20

The Waldensians anticipated Luther and the Reformation by teaching directly from the scriptures and in their own language. "They regarded the visible Church as corrupt

\footnotetext{
${ }^{19}$ Lecler, Toleration, p. 93.

$2{ }^{\circ}$ Carl E. Lindstrom, struggle for a Free Church (n.p.: Conservative Baptist Seminary Faculty, 1948), p. 44.
} 
and its orders as invalid; they resisted or enacted all attempts to silence their puritanical and pacifist gospel."21 The Catholic Church failed to eradicate their heresy and they survived into the era of the Reformation. They still opposed the Catholic priesthood and anticipated the "priesthood of all believers" by their teachings. "Waldensian teaching was that because priests Iived too fast and loose, they had lost the power to absolve sins, or even to administer the sacraments." 22

In the fourteenth century in England, followers of the teachings of John Wycliffe called the Lollards went about teaching. Wycliffe had taught that the reform of the Church meant that the scriptures must be upheld as the only authority. This meant, also, that Christ was the head of the church and not the pope, and that the Scripture should be translated into English, which Wycliffe himself accomplished. The Lollards went further than Wycliffe by forming separate churches, following lay men and women preachers and teachers of the Bible, and organizing their own schools for instruction in and distribution of vernacular Bibles.

Although Wycliffe himself escaped a martyr's death, the influence of his writings and of the movement he

\footnotetext{
${ }^{21}$ Euan Cameron, The Reformation of the Heretics (Oxford: Clarendon Press, 1984), p. 1 .

22 Cameron, Reformation, p. 77.
} 
began had such great effect both in England and on the continent, that the council of constance, meeting thirty years later in 1415, considered them so disturbing that by a special decree, ordered his body be exhumed and burned.23

He has been called by many scholars such as John R. Green, the first Protestant 24 and by A. G. Dickens as the one who anticipated Luther. ${ }^{25}$ Although there were many differences between them, the Anabaptists also found similarities with the later Lollards in their views of religious liberty when they emigrated from the Netherlands into England in the early 1530s.

The contributions of Christian humanism, such as the writings of Nicholas of Cusa, and Marsilio Ficino, were influential in promoting the neo-Platonism that became a basis for condemning materialism, immorality, and secularism in religion. Of course, the greatest influence of humanism was Erasmus and his call for tolerance, peace, and unity. ${ }^{26}$ He called for tolerance toward heretics for the sake of peace. ${ }^{27}$

Luther's early treatise on Christian freedom was the greatest influence for the individual conscience in a spiritual context of the early Reformation. Its emphasis

\footnotetext{
${ }^{23}$ Lindstrom, struggle, p. 47.

$24 \mathrm{John} \mathrm{R}$. Green, A Short History of the English People (New York: A. L. Burt Company, 18741, p. 304 .

${ }^{\circ}$ A. G. Dickens, The English Reformation (New York: Schocken Books, 19651 .

'Lecler, Toleration, vol. I, p. 118.

Lecler, Toleration, vol. I, p. 120.
} 
was on freedom from priestly power and the laws of the Old Testament and church. It was not freedom of thought or judgment. 28 "The conscience must not be bound by anything except by the Word of God."29 However, later, he advocated the established church and accepted the prince's power to compel his subjects to be instructed and to listen to preaching.

The Anabaptists would go further than any group before them with the ideas of personal and social religious liberty. They became true pioneers in the Reformation era and beyond in envisioning a separated and free church.

II.

The term religious liberty can have many interpretations. For the purposes of this thesis, it will be discussed in its contemporary form as it can be applied to the Anabaptists. In the section on religious liberty, only definitions will be presented from modern authors on the subject. The purpose of the definitions is to give clear understanding of what religious liberty is, what it means in twentieth century values, and the major basis for its existence and application. This

\footnotetext{
${ }^{28}$ Lecler, Toleration, vol. I, p. 149.

29Martin Luther, De Servo Arbitrio of 1525, in Lecler, Toleration, p. 149 .
} 
section will not include religious liberty in discussions of natural law or philosophical interpretations. Though there are other philosophical bases for religious liberty, the Christian basis will be the main one considered here, for I believe that it is the primary contribution to the concept. It is generally accepted by religious and non-religious thinkers alike that religious liberty and its related concept, liberty of conscience, are inalienable rights. Such thought would constitute a study in itself and is not within the purpose of this thesis.

Because the word "tolerance" is often used as a synonym of religious liberty, an explanation of the differences between the idea of toleration and that of religious liberty is necessary. This thesis is not dealing with toleration except as is "psychological" tolerance. The use of the term "tolerance" as equivalent to religious freedom poses problems. One modern thinker states,

We must register our view that "tolerance" is again another very equivocal word. This ambiguity is so great that in some cases it is used even in a sense of opposition to or, at least, a limitation of religious liberty as, for instance, when it is said that Protestants are tolerated in Spain, by which is meant a restricted and discriminating permission. In the best meaning of the term, "tolerance" expresses the moral attitude and also moral duty of respecting opinions different from or opposite to 
our own insights. It seems obvious, that tolerance may be the moral motivation which can lead people to recognize and respect the religious freedom of others, but in no way is it the same thing as religious liberty itself. Furthermore, tolerance, moves on a different level from religious liberty, namely in a "moral" sphere. Religious freedom ... social religious freedom ... may have theological and moral motivations, but its sphere of exercise is a resolutely social and juridical one. It is from this confusion that the opinion emerges that Christian love demands tolerance ... religious freedom from every Christian. Christian love commands respect for human activities which are legitimate in themselves and which man has the right to perform in freedom from external coercion. ${ }^{30}$

W. K. Jordan's definition of the term tolerance ${ }^{31}$ adds further clarification.

In its legal application the word toleration signifies simply a refraining from persecution. It suggests at least latent disapproval of the belief or practice which is tolerated, and refers to a somewhat limited and conditional freedom. It involves, as well, volitional action or state of mind on the part of the dominant party towards a weaker party. In its very nature, however, it disapproves, if it does not disallow, the point of view which is to be tolerated. Toleration, therefore, falls considerably short of religious liberty. It presumes an authority which has been and which again may become coercive; an authority which for subjective reasons is not brought to bear upon the dissenting group. The ideas of toleration may be said to spring from the theory that the civil power has inalienable and absolute prerogatives. Liberty of conscience, on the other hand, springs from the theory that the final object of the state is man, that man is responsible for his own actions,

\footnotetext{
30A. F. Carrillo de Albornoz, The Basis of Religious Liberty (New York: Association Press, 1963), pp. 89-90.

$31_{\text {At }}$ the beginning of his four-volume study of the development of religious toleration, vol. I.
} 
and that the State assumes no responsibility for his thoughts or beliefs. ${ }^{32}$

The Anabaptists case bears out and exemplifies Jordan's views.

The last definition of the differences between tolerance and religious liberty comes from a Baptist spokesman, George Truett, from an address given from the east steps of the National Capitol in Washington, D.C., on May 16, 1920, in connection with the annual session of the Southern Baptist Convention at a time in history when the subject of religious liberty was in the forefront of discussion, stemming from the recent memories of the great conflict of world War I.

There is a wide difference between toleration and liberty. Toleration implies that somebody falsely claims the right to tolerate. Toleration is a concession, while liberty is a right. Toleration is a matter of expediency, while liberty is a matter of principle. Toleration is a gift from man, while liberty is a gift from God.33

I will attempt in the next four paragraphs to explain what I personally mean by liberty of conscience as I understand the term.

By liberty of conscience I mean inner liberty of belief, thought, ideas, presuppositions in all areas of existence: spiritual, psychological, moral, intellectual

\footnotetext{
${ }^{32} \mathrm{~W}$. K. Jordan, The Development of Religious Toleration in England, 4 vols. (Massachusetts: Peter Smith, 1965), vol. I, pp. 17-18. ${ }^{33}$ George W. Truett, Baptists and Religious Liberty (Nashville, Tennessee: Southern Baptist Convention, 1920), p. 7 .
} 
and emotional. Also, it means the acting upon conscience or expression of conscience in outward ways. One can actualize one's conscience. For example, choosing to go to church or not to go is acting upon one's conscience. By freedom of conscience as part of religious liberty, I mean the freedom to be separate and free from the state and/or community either spiritually or physically or both. This is part of religious liberty in its social or civil sense. In that way religious liberty and freedom of conscience become political and social, as well as individual and inward. Religious liberty also relates to the state or community in terms of responsibility and therefore of "limits."

Liberty of conscience also means the freedom to act in association with people with shared principles. Such groups may take part in evangelistic campaigns or give out literature in public. In the religious sense, it means the right of churches to exist independently of the state. Under a just government, all laws for the protection of the life, property, safety, and the rights of all must be obeyed. If a government is unjust, and attempts to force persons or churches to conform to its ideas of religious worship or thinking, or to prevent such groups from activating their convictions in an 
arbitrary way, then such individuals and churches have the right to disobey in a non-violent manner. It means the right of Christian groups to exist and have their own institutions such as schools.

The freedom of the Christian as Luther taught it is separate from these general aspects of religious liberty and even liberty of conscience. Christian freedom deals strictly with an individual believer's relationship to God irregardless of freedom of conscience. Christian freedom involves choosing to act or not act upon that conscience. A Christian must first act upon obedience to God and his relationship to God, therefore choosing to serve God and be a servant to man in obedience to God, regardless of his autonomy of conscience. The Anabaptists would carry this to its logical conclusion in terms of obedience by encouraging believers to act upon their consciences and their Christian freedom in order to be obedient to God. "We obey God rather than man."34 For Luther, Christian freedom was freedom to be a servant. A Christian is a perfectly free lord of all, subject to none. A Christian is a perfectly dutiful servant of all, subject to all."35 It is by choice that

\footnotetext{
${ }^{34}$ Acts 5:29, New American Standard Bible (Chicago: Moody Press, 1976).

35 John Dillenberger, Martin Luther - Selections from His Writings

(New York: Doubleday and Co.,Inc., 1961), p. 53.
} 
a Christian obeys God and chooses to serve God and man. Luther states,

As an example of such life the Apostle cites Christ, "Have this mind among yourselves, which you have in christ, who, though he was in the form of God, did not count equality with God a thing to be grasped, but emptied himself taking the form of a servant; being born in likeness of men, and being found in human form he humbled himself and became obedient unto death." 36

In conclusion, my thoughts on religious liberty and freedom of conscience, I believe, reflect the protestant Christian consensus that will be presented in the following definitions, although not all of those views necessarily coincide with my own. The main purpose for these definitions and interpretations is to shed more light on the idea of religious liberty in order to appreciate the contributions of the Anabaptists and to show what the Anabaptists accomplished four centuries ahead of their time. Though unknowingly, they pioneered in the idea of religious liberty.

A. F. Carrillo de Albornoz's book, the Basis of Religious Liberty, is the result of the Third Assembly of the World Council of Churches, held in New Delhi in 1961. The Secretariat for Religious Liberty sought to provide churches and the general public with their definitions and purposes of the subject of religious liberty and its 
basic descriptions such as freedom of conscience, and the social freedoms of individuals and groups. The most important issues that were discussed and decided upon were: the nature of religious liberty, or what is religious freedom; the basis of religious liberty or the grounds upon which freedom is claimed, such as Christian theology, and conditions for securing religious liberty. Carrillo de Albornoz's main reason for writing a book about religious liberty he expresses as follows: "This care for religious freedom is all the more urgent, and necessary in that freedom in general and religious liberty in particular are being abridged in the world today and may continue to be so. Therefore, it is our duty as Christians and as men to claim and to defend this fundamental liberty."37 The basis of religious liberty is Christian theology. ${ }^{38}$ In order to make religious liberty secure, it must exist in a free state. It must be free from coercion. The free state by definition "must liberate from social coercion, therefore religious liberty does not only exclude juridical or physical compulsion, but all other possible coercions coming from society, economic, moral, psychological, etc. Matters to

\footnotetext{
${ }^{37}$ Carrillo de Albornoz, Basis of Religious Liberty, p. 9. ${ }^{38}$ Carrillo de Albornoz, Basis, p. 11.
} 
be protected are matters of religion." 39 Thus social freedom is immune from external coercion. In contrast to this is freedom of choice which is internal and natural and is not subject to external coercion, notwithstanding in the area of social liberty it may be.

Carrillo de Albornoz's study of the World Council of Churches' definitions of religious liberty and liberty of conscience shows that religious liberty in general has four areas that may or may not be related. The council's view is that they are intertwined and they all constitute social religious liberty. I feel both positions can be accepted, especially in relation to the Anabaptists. Most of the central arguments focus on the relationship of pure religious liberty to social religious liberty. For them, pure religious liberty is inseparable from social religious liberty. Pure religious liberty is "the liberation of man from every social compulsion concerning his essential relations with God."40 pure religious liberty is equated with liberty of conscience--social religious liberty is the human right of expression, of association, and of exercising corporate freedoms. However, pure religious liberty is also one of these four religious freedoms, all of which are designated as social

${ }^{39}$ Carrillo de Albornoz, Basis, p. 16.

${ }^{40}$ Carrillo de Albornoz, Basis, p. 24. 
religious liberty. They are as follows: Pure religious liberty or liberty of conscience, liberty of religious expression, liberty of religious association, and liberty of corporate or institutional religious freedom. All of these are social and external and are mixed. The argument also admits that conscience involves thoughts, feelings, decisions, and motives. Freedom of thought, even if, from the Christian perspective, that thought may be in error, is the freedom to think and decide one's own destiny. However, the primary foundation for liberty of conscience is Christian truth and morality, as opposed to other philosophical or legal basis. From that premise, religious liberty is the foundation of all human rights, including political and civil rights. Liberty of conscience is internal and personal where it relates to pure religious liberty and external where it relates to social religious liberty. ${ }^{41}$

From the Christian perspective, there are biblical and theological grounds for religious liberty. From this, the theological basis, according to Carrillo de Albornoz, is Christian-revealed truth. The implication of the Gospel is that God is concerned with the whole man and man's well-being, the freedom of the churches, and

${ }^{41}$ Carrillo de Albornoz, Basis, p. 24. 
inner Christian freedom. Christian freedom is that in which we decide our faith. Christian liberty, according to Carrillo de Albornoz, is not the same as liberty of conscience, though closely related to it. Christian liberty is spiritual and cannot be given or destroyed by anything, whereas social religious liberty can be taken away. Most historians and theologians believe that social religious liberties are based in the Gospel and should be demanded by Christians of society because of inner Christian liberty. Others think that inner freedom and social liberties are totally different and should not be demanded as a right because of inner liberty. One is independent of the other. "Persecutions are announced in the Bible as almost the normal situation for the Church in many ways, and the same persecutions purify and strengthen Christianity. Therefore, it is wrong to say that inner Christian freedom necessitates social freedom."42 This view could be applied to the Anabaptist non-resistance, but so also could the view that inner Christian liberty is related to social religious liberty and that it is a part of social religious liberty and the latter can be demanded because of the former. The basis in the New Testament for this view is that the freedom

${ }^{42}$ Carrillo de Albornoz, Basis, p. 59. 
that Paul spoke of in Christ is not solely private and spiritual, but also a social-historical reality operating in the world. It is independent from coercion but related to external expression and mission. The conclusions of this view are:

Paul's radical view of Christian freedom, also Jesus' words in John $8: 32$ and Matt. 17:24, identified with the life of the spirit, with joy, peace, and glory; carries with it an irresistible pressure, and one that is not only spiritual, whether in Church or in state. That this pressure is defined in terms of love and suffering does not mean that public and worldly historical interests and patterns are not rudely unsettled and overturned; the impact of the Gospel on Ephesus, Acts 19.43

Therefore, the Christian is required to respect the freedom of his fellow believers and fellow man, but also the state and society are equally obliged to do so. Both views can be correct in a given historical situation, and the general view is that pure religious liberty and Christian inner freedom cannot be given or coerced, but they relate to and can act upon or promote social religious liberty of expression, association, corporate activity or outreach.

To clarify the difference between Christian freedom and pure and social religious liberty Carrillo de Albornoz states,

${ }^{43}$ Carrillo de Albornoz, Basis, p. 61. 
From the very first mention of the concept of Christian Iiberty, (particularly as proclaimed by the churches of the Reformation) it is evident that this is not the same thing as social external religious liberty. It seems plainly evident that social freedom to take and to actualize religious decisions free from social coercion is not the same thing as internal freedom in Christ. The main proof is that they can exist separately, as we see in the Christian martyrs. ${ }^{44}$

Another modern thinker, Searle Bates, defines liberty as the

absence of compulsion or restraint. Yet, it is more than the merely negative; it is the opportunity to do and to be something of value. Liberty to do what is evil or futile or stupid is the necessary converse of true liberty, for without choice there is no freedom and no moral personality. Liberty for the individual and the group necessarily implies respect for the liberty of other individuals and of other groups, else it becomes domination and privilege to the damage of the liberty of others. ${ }^{45}$

Religious liberty is more than an individual matter, because the conscience interacts in society. Although the roots of the matter are inner, deep in conscience and conviction, the problems arise in the community. ${ }^{46}$

In relation to church and state, both the idea of a united church and state and that of a separated church are to be considered here. The major point of view shown here is favorable to separation of church and state even though both views are presented. Protestant state

\footnotetext{
${ }^{44}$ Carrillo de Albornoz, Basis, p. 17.

${ }^{45}$ Bates, Religious Liberty, p. 295.

${ }^{46}$ Bates, Religious Liberty, p. 300.
} 
churches of today, especially those of England and Scandinavia, feel that the other religious bodies have a large degree of freedom and that the principle of a national church entails no limitation of Christian freedom and also gives a nation a Christian basis. ${ }^{47}$ Separation often results in the complete secularization of society. Religion is no longer of public interest. Schools, education, and marriage become more of a state monopoly. ${ }^{48}$

The argument for separation is based in the voluntary and spiritual character of religion, by contrast with the coercive and secular nature of the State, even though contact between the two is necessary and desirable. The liberty requisite for religion is likely to be smothered if the organization of religion is bound up with the political system of the state. ${ }^{49}$ Religion is an act of individuality. The existence of a state religion denies the character of religion, it excludes the religious being. 50 "Neither historic absolutism nor recent totalitarianisms and pseudoreligious nationalisms inspire confidence in a

\footnotetext{
4 Bates, Religious Liberty, p. 311.

${ }^{48}$ Bates, Religious Liberty, p. 312.

${ }^{49}$ Bates, Religious Liberty, p. 313.

${ }^{50}$ Bates, Religious Liberty, p. 313.
} 
political organization of religion."51 The New England Baptist leader, Isaac Backus, wrote to President Washington that "religious minorities when supported by force, are the most dangerous men on earth." 52

Francesco Ruffini's definitions and descriptions both differ from and agree with those of authors already discussed. Ruffini gives an historical approach to persons, groups and geographical locations pertaining to the growth of religious liberty. He focuses on the positive aspects of religious liberty, playing down negative features, such as persecution and intolerance by those opposing religious freedom, whether of church or state. ${ }^{53}$ In his book he traces the development of religious liberty from the Middle Ages to its triumph in modern times, even among those who formerly were its antagonists such as the various ecclesiastical establishments of the Lutheran, Catholic, and Calvinist churches in the sixteenth and seventeenth centuries. Only his definitions will be considered here.

From Ruffini's view, the idea of religious liberty as a philosophical idea is rejected and replaced by the area of the juridical, because he sees religious liberty

\footnotetext{
"Bates, Religious Liberty, p. 313.

s John M. Mecklin, The Story of America's Dissent (New York: Harcourt, Brace, 1934), p. 157, quoted in Bates, p. 313. ${ }^{3}$ Francesco Ruffini, Religious Liberty (London: Norgate, 1912), p. 5 .
} 
more separate in relation to freedom of conscience. Also he does not see a theological basis for it. "Religious liberty is not, like free thought, a philosophical idea or principle, it is not, like ecclesiastical liberty, a 'theological' idea or principle; but it is an idea and a principle essentially juridical; nobody ought, for religious motives, to be persecuted or deprived of full juridical capacity."54 In speaking of the idea of toleration in contrast with and in relation to religious liberty, Rufini states,

Toleration, or rather, intolerance, may be simply religious; and it consists in the exclusivist notion that a definite religion must be the only true one. So long as this intolerance, availing itself of purely spiritual arms, confines itself to repelling everything that opposes its dogmas, it cannot be regarded as unjustified and cannot be opposed except by purely spiritual arms. For to wish to impede it otherwise would be to do a grave injury to the principle of liberty of conscience. The word toleration presupposes the existence of a religious state, that is, a state which believes it necessary for itself to make a profession of a certain religion. Hence the religion professed by it will be called the official religion, the established religion. Compelled by necessity to admit other religions within its territory, it will not be able to do so without disapproving them and regarding them with a certain pious aversion; in other words, it will tolerate them." 55

After describing the specific laws in countries such as France and Italy, where it was insisted that the laws are

\footnotetext{
${ }^{54}$ Ruffini, Religious Liberty, pp. 4-5.

${ }^{55}$ Ruffini, Religious Liberty, p. 10.
} 
worded so as to make every religion equal to all others in terms of freedom, he states,

The modern state can no longer have cognizance of "toleration," but only of liberty, because, the former means a gracious concession made by the state to the individual; while the latter, is a duty of the citizen toward the state. Religion is now a domain in which the state can give nothing, but in which the citizen can claim all. ${ }^{56}$

In describing liberty of conscience or of faith, he writes,

This form of religious liberty as the privilege of the individual to believe in what religion he pleases, or to believe in none, it does not come within the juridical field, as being an essentially internal, privilege. It may be object of pure psychological and philosophical inquiry; and therefore ridiculous to sanction it in laws of liberty. Liberty of conscience cannot be subject to exclusions and limitations except such as are imposed by common law. ${ }^{57}$

Ruffini describes social religious liberty as, of course, connected to or separate from liberty of conscience, in that it also is an expression of conscience, publicly and collectively. "Religion is the field in which the sociable character of man expresses itself most imperiously, hence religious liberty will not be complete where there is no privilege of collective as well as individual manifestation, propaganda, and exercise."58

\footnotetext{
${ }^{56}$ Ruffini, Religious Liberty, p. 11

${ }^{57}$ Ruffini, Religious Liberty, pp. 11-13.

${ }^{58}$ Ruffini, Religious Liberty, p. 13.
} 
In discussing the relationship between religious liberty and separatism, Ruffini acknowledges that the first of the proponents of the idea were the Anabaptists, who opposed all interference or support by the state.

The Anabaptists and all their numerous affiliations, immediately began to oppose such interference. It was by these 'sects' that the principle of liberty was transplanted to North America; and it is because of this fact that it made progress and became imposed as a principle connected with that of separatism. And thus it is that religious liberty and separatism have become in America two terms which, historically, and practically, are inseparable. The same is true of European writers who chose to extol the American system of separatism as opposed to Erastianism. ${ }^{59}$

John Acton's definition of liberty pertaining to the individual and the separation of the personal spiritual sphere and that of the state, is worth noting.

By liberty I mean the assurance that every man shall be protected in doing what he believes his duty against the influence of authority and majorities, custom, and opinion. The state is competent to assign duties and draw the line between good and evil only in its immediate sphere. Beyond the limits of things necessary for its well-being, it can only give indirect help to fight the battles of life by promoting the influences which prevail against temptation: religion, education, and the distribution of wealth. ${ }^{60}$

Acton, an English Catholic, understandably had no sympathy for Protestantism, except for the political

\footnotetext{
${ }^{59}$ Ruffini, Religious Liberty, p. 16. $60 \mathrm{John}$ Acton, History of Freedom and Other Essays, Introduction by John N. Figgis and Reginald V. Laurence (London: Macmillan \& Co., 1907), pp. 3-4.
} 
views of Independents, and the religious "sects" that have promoted liberty of conscience.61 "His ideal in the political world was, that of securing 'suum cuique' to every individual or association of human life, and to prevent any institution, however holy its aim, acquiring more."62 The passion of his life was to promote for all individuals the freedom as God intended them to live. He believed each person has the right to be the best. 63

A more recent Catholic perspective has come to the fore through the discussions of freedom in all its moral and philosophical forms at the Patrick T. Healy Conference on Freedom and Man, held at Georgetown University in 1964. During this conference, religious freedom was discussed by John Courtney Murray, S. J. Participants examined the views and positions taken by the Catholic Church regarding the differences between the theory of religious tolerance and the theory of religious liberty as they had developed since the nineteenth century. The older theories of religious tolerance had become systematic from the post-Reformation era, after the Peace of Westphalia, 1648, to the nineteenth century in the course of the conflict between the church and

\footnotetext{
${ }^{6}$ Eiggis, History of Freedom, p. 28. ${ }^{62}$ Eiggis, History of Freedom, p. 18. ${ }^{63}$ Figgis, History of Freedom, p. 26.
} 
continental laicism. This theory of tolerance had been accepted by Pope Leo XIII on one level of his doctrine, on which he was concerned with the defense of the Catholic nation-state against the inroads of laicism.

The theory of religious tolerance takes its start from the statement, considered to be axiomatic, that error has no rights, that only the truth has rights, and exclusive rights. From this axiom a juridical theory is deduced, which distinguishes between "thesis and hypothesis." The thesis asserts that Catholicism, per se, should be established as the one "religion of the state," since it is the one true religion. It follows by logical and juridical consequence that no other religion can be allowed within the state. Error has no rights. Therefore error is to be suppressed whenever and wherever possible, intolerance is the rule. Error, however, may be tolerated when tolerance is necessary by reason of circumstances, that is when intolerance is impossible; tolerance remains the exception. Tolerance therefore is "hyothesis," a concession to a factual situation, a lesser evil. ${ }^{64}$

This theory was rejected by the council because of the more liberal influence of Pope John XXIII. It was acknowledged by Pope John XXIII that religious freedom is a human right because it is an exigency of human dignity.65 And it required sanction and guarantee by human law.

It is understood to be an immunity, a freedom from coercion. The immunity is twofold. A man may not

${ }^{64}$ John Courtney Murray, S. J., ed., Freedom and Man (New York: P. J. Kenedy and Sons, 1965), p. 134.

65 Murray, Freedom, p. 134. 
be forcibly constrained to act against his conscience, and he may not be forcibly restrained from acting according to his conscience. Religious freedom is immunity from coercion in what concerns religious worship, observance, private, and witness, both private and public and social. 66

Protestant and Catholic theologians at the conference agreed on these principles.

It is only appropriate to end this presentation of these definitions of religious liberty with the Baptists. E. G. Hinson's book strongly claims the historical, intellectual, and juridical roots of religious liberty as being the dominant contribution to society by the Baptists, primarily in England and America. Another emphasis of Hinson's book is his concern about the lack of interest in the matter of religious liberty, not only by society in general, but by the Baptists themselves.

Virtually all Christian communions have come to see the central importance of religious liberty as a Christian doctrine. One group in particular, the Baptists, have a right to be proud of the role they played in seeing this doctrine embodied in our Constitution. But, tragically, Baptists in America are almost totally unaware of their greatest contribution to the free world ... the doctrine of religious liberty. It is also true that recent Supreme Court decisions indicate that our nation as a nation is retreating from its original commitment to personal liberty. ${ }^{67}$

\footnotetext{
${ }^{\bar{\sigma}}$ Murray, Freedom, p. 135.

${ }^{67}$ E. G. Hinson, Religious Liberty, the Christian Roots of our Freedoms (n.p.: Glad River, 1991), p. 7.
} 
Hinson's definitions agree with the authors already

cited, but need to be briefly included.

As I use the term 'religious liberty', it is not to be equated with freedom of choice or will or freedom of conscience; it includes these, but is broader. It means the freedom of every human being, as an individual or in a group, from social coercion in religious matters. Further, religious liberty is not the same as religious toleration. Tolerant persons may permit others to exercise their faith, but they do not recognize this as an inherent right. Governmentally, toleration is a policy of permitting forms of religious belief and worship not officially favored, established, or approved. 68

Hinson defines religious liberty as that which

encompasses several freedoms. One is freedom of conscience, the right freely to determine what faith one will follow; others are freedom of religious expression, of association, and freedom for corporate activities. Throughout his study, the sobering warning recurs, "The preservation of religious liberty requires constant and unfailing vigilance. It was obtained at a high price, and it is maintained at a high price."69

Another well-known Baptist, who gave his life in World War II for the cause of liberty, Rufus Weaver, championed liberty by teaching Baptist youth about the contribution and heritage of their faith. His was a world view of freedom for all men everywhere and he not

\footnotetext{
${ }^{68} \mathrm{Hinson}$, Religious Liberty, p. 13.

${ }^{69} \mathrm{Hins}$, Religious Liberty, p. 13.
} 
only wrote and taught it, but gave his life for it. He was a modern day "Anabaptist." His forceful warnings and proclamations concerning religious liberty give further view of the Baptist vision of freedom and democracy.

Freedom to choose that which the individual reveres implies the right to choose those whose rulership he acknowledges. If man possesses the right to choose the object of his worship, he certainly has the right to elect those who shall govern him. Therefore the liberation of all men everywhere in the world from coercive control in the realm of religion is the only sound basis for a functioning democracy. Modern history clearly shows that there is a close relationship between religious liberty and all other liberties that civilized men believe they have the right to claim and to enjoy. ${ }^{70}$

It is hoped by having looked at these insights and views of the idea of religious liberty in general, and its specific aspects, namely, liberty of conscience and the logical results of these in the idea of separation of church and state, that a basis for understanding the convictions and actions of the Anabaptists can be determined.

\section{III.}

In order to understand the nature and significance of what the Anabaptists and specifically their founder, Conrad Grebel, sought to achieve regarding a free church, it is expedient to see the background of the forces and

\footnotetext{
${ }^{70}$ Rufus W. Weaver, Champions of Religious Liberty (Nashville, Tennessee: Southern Baptist Convention, 1946), p. 12.
} 
influences that would bring about that achievement. The achievement was accomplished in the midst of the political, religious, and cultural context of the Reformation in Switzerland, and in the Zwinglian Reformation in particular. The result was the Anabaptist contribution to the idea of religious liberty and liberty of conscience.

The specific reasons why the Anabaptists came out of the Zwinglian Reformation and not the Lutheran or the Catholic will in general be shown here in the different contexts of the Protestant Reform. I believe that the radically advanced views of the Swiss Anabaptists, at least regarding religious liberty, are due, in part, to their connection with Zwingli, humanism, and the political-historical context of Switzerland. That is not to say they could not have come from the Lutheran context, as did Andreas Carlstadt and Thomas Münzter, but the Zwinglian influences were an important basis and incentive for their further radicalism. The humanist and social contexts have things in common, but ultimately it was the interpretations of Scripture, history, and the Church that formed the basis of their separation from Zwingli and all the other protestant reformers. 
At the opening of the sixteenth century, the swiss Confederation was comprised of thirteen cantons. ${ }^{71}$ After three centuries of determined independence through battles and defensive wars against imperial forces, the Swiss emerged as a free country. ${ }^{72}$ The Swiss were known for their fierce patriotism and nationalism and selfconfident city-states, "democracies," and local governments.

The Canton of Zurich had joined the Swiss Confederation in $1351 .{ }^{73}$ The city-state of Zurich had advocated and developed a strong central government that was paralleled in other major cities in Switzerland and other parts of Europe. Rural areas had favored decentralization, fearful that centralized cities would threaten their democratic institutions. This conflict had resulted in the Stanser Agreement of 1481, which continued the decentralized structure of the federation. However, Zurich continued to develop a centralized government.

Toward the cities the rural cantons exhibited a jealousy which had for a long time prevented any additions to the confederation and caused trouble in federal politics. It was feared that the cities

\footnotetext{
${ }^{71}$ Samuel M. Jackson, Huldreich 2wingli, The Reformer of German Switzerland 1484-1531 (New York: Knickerbocker Press, G. P. Putnam and Sons, 1901), p. 4 .

${ }^{72}$ Potter, Zwingli, p. 1.

${ }^{73}$ Potter, Zwingli, p. 49.
} 
would endeavor to absorb the powers of the rural States, or by their votes enact measures oppressive to the country people. ${ }^{74}$

The development of the Zurich magistracy's relationship to the church was facilitated by this development of central government. That this government was well established before the Reformation is why Zwingli could apply his views of church and state to the reform program. ${ }^{75}$ The Reformation was accepted in the cities first and only later in the countryside, ${ }^{76}$ despite the influence of Luther's ideas on the Peasants' War of 1525 and the fight for local freedoms that caused internal conflicts in Zurich. The cities in Switzerland continued to exercise control over both their internal and surrounding rural areas. In zurich power was held by the Zurich magistracy, made up of a small council of fifty and a great council of 212 members. In relation to the church, the council increased its authority over the territorial church, which included several areas of jurisdiction. It claimed a right of guardianship over ecclesiastical matters such as attacking the various immunities of the clergy. ${ }^{77}$ It used several strengthened constitutional reforms to exercise its sovereignty and

\footnotetext{
74 Jackson, Zwingli, p. 5.

${ }^{75}$ Robert C. Walton, Zwingli's Theocracy (Toronto: University of Toronto Press, 1967), p. 3 .

76 Jackson, Zwingli, p. 38 .

${ }^{77}$ Walton, zwingli's Theocracy, p. 5.
} 
supervision over justice, immorality of clergy, and taxexemptions of clergy, and it strengthened all the institutions of ci.ty government.

The corporate theory of government and society which dominated the south German and Swiss cities assumed that church and state were one and recognized neither a distinction between the political assembly of the city and the church congregation, nor any limit to the magistracy's authority. ${ }^{78}$

This is the tradition Zwingli accepted. The fact that it was already developed by the time of the Reformation reflects the political-social changes taking place in the period. The place of the magistery in the religious life of the community was as natural to zwingli as the separation of church and state is to the American Protestant. ${ }^{79}$

The context of Zwingli's theology must be understood within the sphere of the cultural and social factors which shaped it. This must be understood when contrasting it with Luther's theology. Zwingli's life and background were different from Luther's, and this difference was manifested in their different approaches to ministry and views of the church in relation to the state. It was different with respect to their interpretations of Scripture after the essentials of the

\footnotetext{
78 Walton, Zwingli's Theocracy, p. 5.

${ }^{79}$ Walton, Zwingli's Theocracy, p. 16.
} 
Gospel, 80 yet it was scripture that was primary in the views of both. Zwingli's experience as a parish priest and army chaplain in contrast to that of Luther as a monk and professor, constituted one of the personal differences. The context of patriotism and nationalism, and the context of the corporate unity of magistrates and ministers was for Zwingli in total contrast to the context of Luther's situation. For Luther, the spheres of spiritual and temporal were more completely separated.

There is evidence of the patriotism, scholasticism, and humanism, as well as of the study of the fathers, that were to be manifest in his later theology. Under the influence of Erasmian humanism, his preaching had become strongly biblical and christocentric, and he began to preach systematically through the New Testament. ${ }^{81}$

Scholasticism certainly had an affect on Zwingli, but it is little known. He had studied Aquinas and Duns Scotus as well as Occam, while at the University of Vienna. Zwingli did not adhere to any one of the schoolmen but drew freely from all and was considered Aristotelian. He studied the church fathers such as Augustine, and during university study in Basel, came into contact with humanism and the influence of Thomas

\footnotetext{
هuW. P. Stephens, The Theology of Huldreich Zwingli (Oxford: Clarendon Press, 1986), p. 282 .

${ }^{8}$ stephens, Theology, p. 5.
} 
Wittenback, who encouraged him in the study of Greek and the original New Testament. ${ }^{82}$

Zwingli's patriotism was an important element in his theology which was strengthened by his humanism. His love of his country and hatred for the mercenary system reflected his passion for liberty and Swiss independence. "Zwingli's ministry and theology were set in a framework that was social and political, indeed national and international and not simply individual and personal."83 Anabaptists could have been attracted to Zwingli for these reasons, but carried them much further.

Perhaps the greatest influence on Zwingli outside the Scripture was that of Erasmian humanism. He read the classics of Greece and Rome such as Plato and Aristotle, Homer and Cicero. He could find moral truth in pagan writers as much as Augustine, as long as they were applied to scriptural truth. ${ }^{84}$ Though Zwingli admired Erasmus and attributed to him his Christocentric theology and saw Erasmus as the one who had freed the Scriptures from scholasticism, he also saw an ambiguity in Erasmus and would criticize Erasmus' view of Christ as teacher and example only and his poems dedicated to saints. ${ }^{85}$

\footnotetext{
82 Potter, Zwingli, pp. 15-19.

${ }^{83}$ stephens, Theology, p. 8.

${ }^{84}$ stephens, Theology, p. 9.

${ }^{85} \mathrm{Z}$ II 217.5-218.8V. Huldreich Zwingli, Sämtliche Werke (Zurich:

n.p., 1905), p. 260, in Stephens, Theology, p. 10.
} 
The area in which zwingli was most influenced by humanism was his theology of man. There are inconsistencies and ambiguities due to the dichotomy resulting from the neoplatonic influences of his humanism. ${ }^{86}$ Zwingli believed man was created in God's image, but only in terms of mind and soul, not body. What happens in the body is separate from soul and intellect. Yet man is a sinner, has basically two natures, flesh and spirit, and both are fallen. Man is totally dependent on God's mercy for salvation through faith in Christ alone.

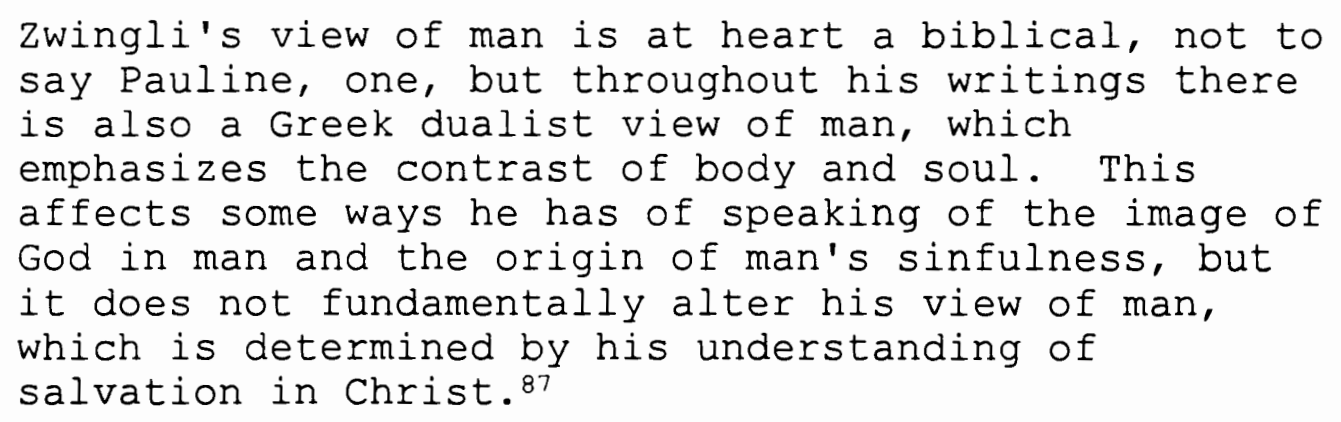
say Pauline, one, but throughout his writings there is also a Greek dualist view of man, which emphasizes the contrast of body and soul. This affects some ways he has of speaking of the image of God in man and the origin of man's sinfulness, but it does not fundamentally alter his view of man, which is determined by his understanding of salvation in Christ. ${ }^{87}$

Zwingli believed that original sin was a condition into which man was enslaved. Man, the fall of man, original sin, and guilt, are all related to the work of Christ. Salvation is by God's grace through faith. Faith depends, for Zwingli, on election. ${ }^{88}$

\footnotetext{
${ }^{86}$ Stephens, Theology, p. 144.

${ }^{87}$ Stephens, Theology, p. 153.

${ }^{88}$ stephens, Theology, p. 152.
} 
Zwingli's view of infant baptism relates to his view of original sin. He makes infants immune to the guilt of original sin, but not because of any holiness of the parents. Yet, he makes baptism a pre-condition of faith on the basis of equating it with circumcision. "It is the nature of original sin by itself to damn, for it leads to actual sin. However, Christ has made good what Adam did. He has obtained salvation from original and actual sin, so that it does not damn those who trust in him or their children."89 The baptism of infants then pre-supposed their faith. The Anabaptists would oppose Zwingli on that point saying that baptism could only come about as a result of adult faith or a child who had reached an age of understanding. One of the reasons for their opposition to infant baptism, besides their understanding of Scripture, was that it prevented the adult's personal obedience to Christ's command. "The evil effects of infant baptism are a strong argument against it. In forestalling the voluntary act of the child baptized, it thus practically prevents his personal obedience to Christ's commands. The person baptized in

${ }^{89}$ Stephens, Theology, p. 151. 
infancy has never performed any act with intent to obey Christ's command to be baptized."90

Zwingli's doctrine of election or predestination was developed in his later period more systematically, and was nearly the same as Calvin's concept. Though the Anabaptists would emphasize free will as opposed to predestination, the leaders such as Grebel and Hubmaier placed predestination in the "secret decrees" or "mysteries" of God. The following is a general definition of election:

Election is that eternal act of God, by which in his sovereign pleasure, and on account of no foreseen merit in them, he chooses certain out of the number of sinful men to be the recipients of the special grace of his Spirit, and so to be made voluntary partakers of Christ's salvation. Faith, as the effect of election, can not at the same time be the cause of election. While it humbles the sinner, so that he is willing to cry for mercy, it encourages him also by showing him that some will be saved, and (since election and faith are inseparably connected) that he will be saved, if he will only believe. ${ }^{91}$

Zwingli's general theology regarding the primaries of faith was biblical. God was sovereign, the Bible was God's word, the Holy Spirit revealed Scripture and was linked to the word by preaching the Gospel. Christ was central to Zwingli's theology. He was God and man, though the divine nature was emphasized. "Christ is our

\footnotetext{
${ }^{90}$ Augustus H. Strong, systematic Theology (Valley Forge, Pennsylvania: Judson Press, 1907), p. 957. ${ }^{91}$ strong, Systematic Theology, pp. 779-789.
} 
salvation, because he is both God and man. As God he can fulfill the will of God; as man he can be a sacrifice that satisfies the righteousness of God."92

The general context and major principles of Zwingli's theology were the very reasons why the Anabaptists, or the Swiss Brethren, came out of the Zwinglian Reformation. Grebel had the same theological heritage. He and Feliz Mantz had been attracted to Zwingli's patriotism, nationalism, and humanism, and perhaps to his sense of community. The young humanists, like Grebel, who were in the inner circle of humanist scholars surrounding Zwingli, were in agreement and supportive of Zwingli's Reformation until 1523. Though the issue of infant baptism was the catalyst of early conflict between Zwingli and the future Anabaptists, the basic issue was their opposing views of the church, ministry, and Christian life in relation to the state, the community, and the individual. To understand the specifics of the differences, one must look first at Zwingli's view of the church and ministry and its relationship to the state.

For Zwingli, the church was both visible and invisible. The invisible or "spiritual" church is made

\footnotetext{
$92 \mathrm{Z}$ II 162.6-13 cf. Z VI 464-5-17, Huldreich Zwingli, sämtliche Werke, quoted in stephens, Systematic, p. 260.
} 
up of believers only, both in Heaven and on earth; their identity is known only to God. This church is united in Christ as its head. It is a communion of saints, the bride of Christ, the "universal" church. ${ }^{93}$ It is gathered together in one body by the spirit, it does not come together on earth but will at the second coming. The visible church, or local congregation, is nourished by the body and blood of Christ and the Holy spirit. This church proclaims the Word of God and receives the repentant. ${ }^{94}$ Though this church is constituted by the Word of God, only those whose lives reflect their faith are truly Christians. They are, however, mixed among those who are not truly Christians. The holiness of the church is in christ, not in its members. Therefore, those who are not Christians cannot be known to the local congregation. The church includes the whole community, believers and unbelievers. In Zwingli's conflict with the Anabaptists, it was the nature of the visible, not the invisible, church that was in dispute. ${ }^{95}$ The unity of state and church, of course, represents the whole structure and context of the sixteenth century. In order for society to function, it must have this unity.

\footnotetext{
${ }^{93}$ Stephens, Theology, p. 260.

${ }^{94}$ Stephens, Theology, p. 262.

${ }^{95}$ stephens, Theology, pp. 262-263.
} 
IV.

The Anabaptists, in my view, could only have come out of the Zwinglian Reformation also because of the parallels in the life of their founder with Zwingli himself. Zwingli's patriotism, and humanism shaped his reform; it also shaped the life and reform of Conrad Grebel -- except that Grebel would take that reform to radical conclusions. They shared the same national, cultural, and educational heritage. They both went to the universities in Vienna and Basel. They both became part of the humanist circle north of the Alps.

Conrad Grebel was born into an established patrician family of the lesser landed nobility of zurich which had first established itself in the city in 1435. Conrad's father, Jacob Grebel, was a member of the Zurich city council and served as a magistrate. Conrad had the traditional late medieval education in the local Latin school. The chief subjects taught were Latin grammar and literature, dialectic and music. ${ }^{96}$ The art of disputation, mainly with theological themes, was taught. After the humanist Oswald Myconius taught there in 1516, the new humanist type of learning began in the Latin

\footnotetext{
${ }^{96}$ Harold Bender, Conrad Grebel (Goshen, Indiana: The Mennonite Historical Society, 1950), p. 221.
} 
school at the same time it was beginning in the universities. Grebel studied at the University in Basel from 1514 to 1515, and there he became a student of the great Swiss humanist Glarean and was acquainted with his intimate circle. It was under Glarean's influence that Grebel began his development as a humanist in his own right. It was here that the great Erasmus studied and taught between 1514 and 1516 so that the two groups surrounding Glarean and Erasmus interacted with one another and Grebel benefited from both.

Glarean was an excellent teacher, and under his tutelage the young Grebel was introduced for the first time into the world of humanist learning and living. Basel was barely beginning to come into its glory as a humanist center. Erasmus had come two months before, in August 1514, to remain through the winter. The great Froben had begun his career as an independent printer the year before in 1513. The foreigners gathered around Erasmus, while the young Swiss gathered around Glarean. ${ }^{97}$

In September 1515 Grebel went to the University of Vienna, where he studied until 1518.98 Here he met the humanist teacher Vadian [Joachim Watt], who would become his close friend, confidant, and brother-in-law. Grebel's experience in Vienna with Vadian was the most formative of his life prior to meeting Zwingli. Under Vadian's influence he developed interests in the new

\footnotetext{
${ }^{97}$ Bender, Grebel, p. 162.

${ }^{98}$ Bender, Grebel, p. 163.
} 
subjects of geography, geology, history, and science. ${ }^{99}$ Grebel studied Greek, Latin, Hebrew, and the classics as well as geography.

Grebel studied in Paris from 1518 to 1520, joining Glarean there after he had left Vienna. Unfortunately, Grebel and Glarean quarreled, which resulted in their permanent estrangement. ${ }^{100}$ But Paris was a turning point for Grebel because, as a result of a brawl which almost cost him his life, he began to think about death, immortality, faith, and God. After his permanent return to Zurich, he continued his inner search for deeper meaning and became a member of the circle surrounding Zwingli. The common bond between them was the study of classical literature such as Homer, Plato, and the ancient Greek and Hebrew Ianguages. ${ }^{101}$ The group included Felix Mantz, who along with Jörg (George) Blaurock, would one day become Grebel's partners in establishing the Anabaptist movement. Grebel's years of development and education, and fellowship with Zwingli had prepared him to become a leader and reformer. All of these elements met in the Zwinglian circle. Grebel's quest for meaning came to fruition under $\mathrm{zwingl} i$ and his preaching at the

\footnotetext{
${ }^{99}$ Bender, Grebel, p. 163

100 Bender, Grebel, p. 163.

101 Bender, GrebeI, p. 165.
} 
beginning of his reform of the church in Zurich. "In Zurich in the person of Ulrich Zwingli Grebel found for the first time a man who merited full recognition as a scholar and a humanist, and who at the same time held a positive Christian position. Thus in Zwingli two streams of influence were united for Grebel; classical antiquity and biblical Christianity."102 Now Grebel began to see where truth lay, and began to perceive Christian faith independently of humanism. So for Grebel, as earlier for Zwingli, humanism became secondary in his life and the Bible primary. The humanism had been a source of preparation and training that pointed the way to complete knowledge of truth and became a methodology in his theology. 103

Grebel's conversion took place sometime in 1522. He had learned to trust in Christ alone and experienced a spiritual change in his life which was reflected in a change of attitude toward circumstances.

Conrad speaks of trust in God and of a desire to learn wisdom and patience. He is willing to bear his burdens. Life is a battleground. The new tone is that of a believing Christian; in place of the old humanistic exuberance we find moderation, simplicity, and objectivity, he expresses the spirit of the Bible. ${ }^{104}$

102 Bender, Grebel, p. 164.

103 Bender, Grebel, p. 165.

${ }^{104}$ Bender, Grebel, p. 77. 
Grebel, as Zwingli's convert, was interested in Luther, Melanchthon, and Jakob Strauss. His chief interest became the progress of the Gospel. He desired only victory for the evangelical cause over the superstition of the old church. He had heard the word of God preached by Zwingli, and his changed life had now reflected that fact.

He became an ardent partisan of Zwingli and his reform program. Zwingli recognized and valued Grebel's support and permitted him to publish a vigorous poetic ode hailing the Reformation in his booklet entitled Archeteler which was published in August 1522. During this time a very close intimate friendship developed between Zwingli and Grebel.105

When Zwingli began to preach the Gospel in Zurich in 1519, and the Reformation of Zurich began, he gradually won the support of the people and the council. His reform had begun against the Catholic mass, invocation of saints, and the use of images. As one of Zwingli's most loyal supporters during the period, 1522-1523, Grebel became a staunch co-worker and partner in Zwingli's reform movement. "The close relationship between Grebel and Zwingli was maintained until the second Zurich disputation between the Zwinglians and the Catholics in October 1523. Grebel was happy to work at Zwingli's side and recognized him as a true and faithful shepherd and

\footnotetext{
105 Bender, Grebel, p. 166.
} 
leader of the church of Christ."106 Only after the second disputation in October 1523 did Grebel's attitude toward Zwingli begin to change from support to opposition. Though the issue of infant baptism was a factor, it was the issue of Zwingli's reliance on the Zurich council for reform of the church, and therefore the differences in their views of the relationship between church and state, that caused their separation.

The first Zurich Disputation of January 1523 had resulted in the decision of the council to permit the preaching against the traditional Catholic mass, use of images, and invocation of saints. But it had not brought about actual change or reform--the abolition of the mass, images, and saints.107 Many people in Zurich desired to reform society completely in line with evangelical Protestantism within the particular form of Zwingli's theocracy. ${ }^{108}$ For the common man, this meant new access to the scriptures, usually in Bible "schools" such as those conducted by Andreas Castelberger in Zurich, as well as in groups around Johannes Kessler in St. Gall.109 This was welcomed by Zwingli as it was what he and the other reformers such as Erasmus, had advocated. However,

\footnotetext{
106 Bender, Grebel, p. 83.

107 Bender, Grebel, p. 88.

108 Bender, Grebel, p. 89.

${ }^{109}$ Bender, Grebel, p. 90.
} 
there was also a certain amount of fear as well on the part of the government, that such Bible groups and the teaching of the Gospel and the priesthood of all believers would influence the common people to demand their freedom from burdensome tithes. There was also the fear that people would become impatient with the delay in reforming the mass. This impatience could lead to the demand of the people to reform the mass at once. Grebel and his fellow associates from Zwingli's group began to see the pressure and conflict of the desire for complete reform among the people and the growing possibilities of discontent and extremism in the populace.110 Zwingli had also feared this and his delay in the decision to abolish the mass was reflected in the second disputation.

The second disputation of October 1523 discussed matters pertaining to the use of images and the mass. Conrad Grebel spoke on the abuses of the mass. He then called upon the council, in a historic appeal, to abolish the mass at that time. The reply of Zwingli was undoubtedly the beginning of their estrangement and separation.

Grebel stood up and expressed the opinion that since the priests were all present that day, they should be instructed regarding the mass so that from this time on the mass would be dispensed with, but if

\footnotetext{
:Bender, Grebel, p. 91.
} 
this were not done, the disputation would be in vain. Zwingli replied, "My lords will decide what measures are to be taken from this point on regarding changes in the mass." Then Simon Stump, one of Grebel's associates, stood up and said, "Master Ulrich this power is not in your hand to turn over to my lords the judgement of the mass into their hand: for that decision has already been made: the spirit of God judges. So, if my lords arrive at some decision and judgement that is against the judgement of God, I will ask Christ for His Spirit and will teach and act against it.111

A revolutionary statement had been made. Zwingli's declaration was an evasion and reflected his view of the state and of his confidence that the majority of the council were Christian in their views of the mass and so would make the right decision when they felt the people were ready. To Grebel and his associates, Zwingli had violated and compromised the main principle of his own reformation -- that the Scripture was the only authority and must not be subjected to the authority of the state. ${ }^{112}$ He had left a church decision in the hands of the city council. Human reason and the civil magistrate were settling matters of doctrine and worship. Prophetically, it was a vision of things to come even though Grebel could not have foreseen it--or could he?113

${ }^{111}$ Emil Egli, Aktensammlung, zur Geschichte der zürcher Reformation in den Jahren 1519-1533, \#463 (Zürich: Druck von J. Schabelitz, 1879), p. 190, in William R. Estep, Anabaptist Beginnings 1523-1533 (Nieuwkoop: B. de Graaf, 1976), p. 17. :12Bender, Grebel, p. 99. $1{ }^{3}$ William B. Ball, "Secularism: Tidal Wave of Repression," Freedom and Faith, ed. Lynn R. Buzzard (Westchester, IL: Crossway Books, 1982), pp. 51-52. 
It was the beginning of two opposite patterns in church history, as well as general history -- one, the way of the state church, and the other, the free church.

The decision of Conrad Grebel to refuse to accept the jurisdiction of the Zurich council over the Zurich church is one of the high moments of history; it marked the beginning of the modern "free church" movement. It was an historical action which, in effect, demanded the separation of church and state, though certainly without conscious awareness of its far-reaching implications. By it Grebel and the Swiss Brethren planted the seed out of which has come, through the influence of the Anabaptists in Holland and England, the modern Protestant commitment of freedom of conscience, freedom of religion, voluntary church memberships and separation of church and state. ${ }^{114}$

In the months that followed the disputation and into 1524, Grebel and Mantz presented their own plan of reform to Zwingli.115 In general their plan called for a complete change in the constitution of the church as it existed and founding a church of believers, according to the Word of God. "Divine righteousness was to be absolute and usury and tithes were to be gone. Ministers of the Gospel were no longer to live from tithes and benefices, but were to be supported by voluntary giving of the church."116 In this church, real commitment to Christian Iife and discipleship were to be preached.

\footnotetext{
114 Bender, Grebel, pp. 99-100.

115 Bender, Grebel, p. 103.

${ }^{116}$ Leonhard von Muralt and Walter Schmid, eds., Quellen zur

Geschichte der Täufer in der Schweiz (zürich: s. Hirzel Verlag, 1952), vol. 1, p. 14.
} 
This church would also set up a truly Christian civil authority in place of the existing city council. This was revolutionary, for they had in mind a Christian government, yet not a theocracy, only a government led by true Christians. It shows that the Swiss Brethren originally wanted a church for all, but it would be a church for believers only. There are several theories as to exactly what Grebel and Mantz meant by a "Christian" council over one that was at least partially "worldly"; and as to what Zwingli meant when he wrote about it in his Elenchus. ${ }^{117}$ Bender asks,

Did Zwingli mean to say that the brethren proposed to substitute a new pious council for the existing mixed (partly worldly) council, or that they proposed two parallel councils, one for the saints and one for the world, or that they were not thinking of a political council at all but rather a church synod? The last interpretation has been adopted by John Horsch in Mennonite Quarterly Review VI, 1923. Horsch's translation is not true to the meaning of the original. Their hope was to displace this council after the pious had secured a majority in the city. The idea of a displacement of the existing council proves that the brethren had originally (1523-1524) proposed to establish a "Christian" government. Later there is no evidence of a maintenance of this idea.118

They did not intend to be a "separatist" church or "sect." They wanted a united church, because they believed most people would accept their program. "Konrad

117Elenchus, op. cit., p. 33, in Bender, Grebel, p. 255.

118 Bender, Grebel, p. 255. 
Grebel came to Zwingli and M. Löwen to discuss with them, that they should form a new church. It should be made up of Christians living in purity and faithful to the Gospel. After Zwingli's outright rejection, they nevertheless met at night with the intention of starting this new church."119 To them this was applying the Gospel and making a complete break with the Catholic Church and the state church in general. But with Zwingli's rejection, they were forced to hold "ally meetings" and "gatherings in the dark" in order to be a church of gathered believers only, according to the scriptural model of a true church. They were compelled to separate from the nominal Christian Church and form their own. For that reason, they were labeled a sect who rejected civil authority and were given a reputation they had not intended to have. All ideas of a united Christian Church were abandoned, because of their historical situation it was impossible. Later the idea of a Christian council was abandoned altogether.

The demand of the Brethren that a serious attempt be made to put the Gospel into practice meant a complete breach with the Catholic Church and with the idea of a state church in general as it existed up to that time, but it meant by no means a "separatist church" or a "sect and a party." Grebel, Mantz, and Stumpf wanted to have only one united church, not a little church outside of the

${ }^{119} \mathrm{Egli}$, Aktensammlung, \#692, pp. 308-309. 
big church, for they believed that the majority of the people would accept their program. They required an earnest and consistent Christianity with a real change in life, they were compelled to separate from the large body of nominal Christian who continued in the old careless way; or rather they were in reality expelled by the great church.120

Because their program for a Christian civil authority had been rejected, and the existing city council continued to compromise and maintain unchristian burdens such as tithes and usury, they could do nothing less than view the council as an unchristian civil authority and Zwingli's church which had united with it as an unholy alliance.

The first acts of "separatism" in the sixteenth century took place as a result of the rejection of Grebel's plan. This led to the realization that he must turn outward from Zurich and establish contacts with like-minded leaders elsewhere. Strong solidarity developed within Grebel's group and it became a popular movement outside of Zurich. Grebel's group developed a network of contacts and external alliances with churches and leaders which caused it to spread all over Switzerland. Grebel and his associates met in homes, conducted Bible studies, discussed doctrine, held prayer meetings, Bible schools, and interacted with the leaders in Wytikon and Zollikon and other towns.

120 Bender, Grebel, p. 104. 
The growth of the movement in St. Gall anticipated Grebel's later success there. During the first half of 1524 the Bible schools, such as those held in st. Gall by the Zwinglian, Kessler, reveal the growth of the popularity of the "pre-Anabaptist" movement in that town. The Bible "school" was transferred from private homes to the guildhall of the tailors, then to that of the weavers, and then to the second floor of the Metzge, which could accommodate a thousand people. In the early fall of 1524, Lawrence Hochrütiner challenged Kessler on the issue of infant baptism and won the support of the people. When Kessler was forbidden by the town council to continue his teaching, the work was carried on by Wolfgang Ulimann, a future Anabaptist, who became a popular leader in St. Gall. ${ }^{121}$

During this time Grebel established contact with Carlstadt, Luther, and Thomas Müntzer in the summer of 1524. Undoubtedly he had read Carlstadt's pamphlets on infant baptism. Grebel saw Carlstadt as having accomplished in Wittenberg what he had hoped to do in Zurich and so established contact with him first. ${ }^{122}$ His letter to Thomas Müntzer reflected the fact that he

\footnotetext{
121 George H. Williams, The Radical Reformation, 2nd ed. Sixteenth Century Essays and Studies 15 (Kirksville, Misouri: Sixteenth Century Journal Publishers, 1992), pp. 222-23.

Egli, Aktensammlung, in Bender, Grebel, p. 108.
} 
thought of Müntzer as a fellow believer whose views of the church were the same as his. Müntzer had not yet gone his own way toward a militant revolutionary method of establishing a church by planning a war against the princes in Saxony and becoming a leader of the peasants' revolt in Milhausen. After that, the Brethren rejected his views and admonished him.

The brother of Huiuff writes that you have preached against the sovereign and said that he should be attacked physically. Is this true? If you wanted to defend war, or other things that can't be found in the clear Word, as you won't find the ones mentioned, I admonish you in the name of all our salvation. If you refrain from all your own judgements now and hereafter you will be purified.123

The Müntzer letter is important for the purposes of viewing the Anabaptist contributions to religious liberty in general and liberty of conscience, and their contribution to the concept of separation of church and state. It reflects their views of the church as a gathering of believers and the Christian life as discipleship.

And while you rightly criticize mixing human words and customs with those of God, you should also break with the priesthood, benefices and all new and old customs, as well as with your own and traditional ideas, so that you become pure. If your benefits, as they are here, are based on interest and tithes, both of which are usury, then it is not the entire

i.sVon Muralt, Quellen, p. 20. 
congregation that keeps you. Please withdraw from that practice. You know quite well where a shepherd's livelihood should come from. And pertaining to the Christian church and life, stick with the word and form a Christian congregation with Christ's help and his law, as we find given in Matt. 18 and practiced in the epistles. Apply yourself earnestly together in prayer and fasting, faith and love, without law or compulsion, and God will help you and your flock to purity. There is enough wisdom and advice in the Scriptures to show how all classes, all men, can be taught, governed and made wise and god-fearing. ${ }^{124}$

The striking element here is these men's world view, the universality of their sense of mission. This unveiled in "all classes, all men, taught and governed" reflects their revolutionary view of the complete restitution of the true church and sense of liberty. Tolerance and liberty toward all men, not just themselves, is seen in the following. "Who does not want to repent and believe and resists the Word of God after Christ and his Word have been preached to him, he should not be killed, so we say on the basis of the word of God, but should be regarded as a heathen and should be left to himself."125 The year 1524 also saw the intensification of the controversy over infant baptism. In Zollikon and elsewhere people were refusing to have infants baptized. other reformers had discussed it and several had rejected or seriously questioned it long before the Anabaptists.

${ }^{124}$ Von Muralt, Quellen, p. 17.

125 Von Muralt, Quellen, p. 17. 
Leaders such as Carlstadt, Erasmus, Oecolampadius, and Zwingli himself in 1521, before he reversed his view, had questioned its scriptural validity. ${ }^{126}$ The controversy led to the public discussions in Zurich concerning the scriptural basis of infant baptism. "Because of the growing intensity of this controversy precipitated by many parents in zurich refusing to baptize their children because they chose to obey the scriptural teaching rather than the laws of the council, public discussions or 'Disputations' were held"127 At many of these discussions, held during the period of December 1524 through January 1525 before the zurich council, Grebel and his associates were not given equal freedom to speak. ${ }^{128}$ As a result Grebel or Mantz wrote the Protest and Defense. Because the authorship of the "Protest" is uncertain, it is presented here as Grebel's in accordance with Bender. However, Leonhard Von Muralt believes that it was the work of Felix Mantz.

We could never get a word in, and also the Scriptures were never examined. They twist your words, cut you off, demand the word of God, and they pretend to teach the truth from it, but God knows. Christ does not teach infant baptism, which was also not practiced by the apostles. The true meaning in that all those should be baptized who repent, turn

\footnotetext{
i 20 Bender, Grebel, p. 27.

127 Bender, Grebel, p. 128.

128 Von Muralt, Quellen, p. 25.
} 
to start a new life, died to their sins, were buried with Christ and raised to life with him in baptism.

As evidence that this is the meaning of baptism we read in the XXIInd Chapter of Acts, 14-16, where Paul told how it was with him on the way to Damascus, 14, "and he said to Ananias, "The God of our Fathers has appointed thee to know his will, why tarry? Arise and be baptized." From this we see what baptism is and when it shall be practiced, namely upon one who has converted. ${ }^{129}$

Zwingli and the Council were poised against the Brethren, and the outcome of the "discussion" was a foregone conclusion as Zwingli was now in total opposition to the Brethren politically. "The situation was now entering upon a new phase. Political considerations now entered what had been a purely religious affair, as the state sought legal grounds for persecution."130 Following the January 17, 1525 disputation on baptism, Zwingli's and the council's attitude toward Grebel and those in opposition to infant baptism were looked upon as being in direct disobedience to the state. This was because infant baptism was required of parents by the state in order to maintain unity and obedience in society. In the state's eyes, it was the glue that held church and state together as one. To go against that, even for the cause of conscience and conviction, was equal to treason. Zwingli and the council had brought the charge of sedition against Grebel and the Brethren. Some

129 Von Muralt, Quellen, pp. 25-26.

130 Bender, Grebel, p. 130 . 
of their numbers were expelled from Zurich.131 This was the great turning point in the Anabaptist's development as a free church movement because it changed the whole character of the historical situation. It moved from being a purely religious controversy to a political one. As "seditionists," the Anabaptists could be accused of being a "revolutionary party" and therefore could be persecuted. Zwingli and the council could view them as a threat to the unity and welfare of the state. Grebel wrote to Vadian informing him of the new developments: "Zwingli is writing on 'force.' Whether he will struggle with the same one, I know not. Zwingli is also writing of 'the disturbers' or 'on making disturbance' it may well strike ourselves. Mark you, it will bring about something. May God send His truth and righteousness and confute all persons."132 The issue of infant baptism and their stand on it had brought the Brethren to their first acts of separatism based on liberty of conscience. Though separation from Zwingli and the state church was their first act of religious liberty reflecting freedom of conscience. Their stand against infant baptism was clearly, a decision according to conscience. They were being obedient to God rather than man and to their principle of the supreme authority of the

131 Bender, Grebel, p. 136.

132 Letter to Vadian, Dec. 15, 1524, Von Muralt, Grebel, p. 30. 
Scripture as they understood it. They practiced adult baptism because of their view of the Christian life and their view of the church. This meant and signified true repentance, changed life, and commitment to Christ. Therefore, only true Christians could be the Church of Christ, and the Church of Christ was voluntary and free. Infant baptism was not just a religious matter. It was political to the core. It would be a study in itself to present its history and origins. To refuse to have a child baptized was a violation of the laws of the state. This violation meant being excluded from the community. It meant being in opposition to the state, or in rebellion against state authority. Grebel and the Brethren were ordered to stop preaching and baptizing.133 This led them to the decision to stand firm in their convictions and to prepare themselves for persecution in the future. Heinrich Bullinger, Zwingli's successor, wrote,

The disputation in January was the first of three taking place in 1525. Instead of bringing an end to the conflict, it actually sparked the Anabaptist movement. When the opponents of child baptism felt they were unjustly condemned by the council at this first disputation, they began to demonstratively distance themselves from the state church by introducing adult baptism and to form their own community. The Anabaptists posed a big problem to

133 Bender, Grebel, p. 136. 
the authorities by travelling and preaching throughout the country. ${ }^{134}$

This led to the historic meeting which took place on January 21, 1525, in the home of Felix Mantz where the first baptism upon confession of faith took place. Grebel baptized George Blaurock, who had joined the group earlier. ${ }^{135}$ From this humble beginning, the Anabaptists went forth to preach the Gospel, baptize, and carry out their program of reform -- the establishment of free and separated churches, and teaching a biblically-oriented way of life as they saw it. The period of great activity, traveling, and accomplishment from January 1525 to October 1525 had begun. Not only did adult baptism represent freedom and individual conscience, but so also did the active application of their ideas in traveling, preaching and evangelization. Speaking out for the Gospel, for adult baptism and its effects in a changed and committed Christian life was also an application of their convictions. Here too is total, positive existentialism. As Friedman has stated, "Ever since the days of the apostolic church, Anabaptism is the only example in church history of an "existential Christianity," where there existed no basic split between

\footnotetext{
${ }^{134}$ Heinold Fast, Heinrich Bullinger und die Täufer (Weiershof, Germany: Geschichtsverein e.v., 1959), pp. 16-17. ${ }^{135} \mathrm{Egli}$, Aktensammlung, pp. 284-286, No. 636 .
} 
faith and life, even though the struggle for realization or actualization of this faith into practice remained a perennial task."136. Friedmann further clarifies what is meant by the use of existentialism when applied to the Anabaptists:

I suggest the term "existential Christianity" for the Anabaptist camp. But by this term I mean something different from what is today often called "Christian existence," which denotes the status of despondency and lostness, the exact opposite of what is implied here by the term "existential Christianity." This latter term means a realized and practiced "Christianity of the Gospel," in which the person has to a large degree overcome the basic dilemma of every Christian believer. He does not experience inner doubt, no feeling of despair, but rather the exact opposite: the certainty of resting in God's gracious hands, of being called and able to respond to this call.137

This existentialism meant the bringing of a person into the right relationship to God, which makes him a genuine follower of Christ. This interpretation of justification may be called existential rather than theological; it does not mean merely an acquittal but an actual change in a person's nature. ${ }^{138}$

Grebel travelled to Zollikon and joined forces with the Anabaptists there. In March he taught pastors in Schaffhausen, endeavoring to win learned preachers for

\footnotetext{
${ }^{136}$ Robert Friedmann, The Theology of Anabaptism (Scottdale, Pennsylvania: Herald Press, 1973), p. 27. 137 Friedmann, Theology, p. 29. ${ }^{138}$ Eriedmann, Theology, p. 88.
} 
the cause of Anabaptism. This shows that Grebel intended to win the educated classes for Anabaptism. His attempt to convert the French nobleman Anemund de coct in Schaffhausen illustrates the appeal of Anabaptism to some of the nobility. ${ }^{139}$

Doctor Sebastian Hofmeister of Schaffhausen reported to Zwingli and the Council of Grebel's activities in that area and his attempts to win him to Anabaptist beliefs along with the nobleman de coct.

Grebel came to him in the company of a French knight (Animudo) and tried to win him (the knight) for the Anabaptist's cause. He talked about child baptism and that the papacy should be abolished. Grebel went on to claim that all preachers supported by the state churches wouldn't dare to preach the truth of the Gospel. He then accused Zwingli of trying to bring down him and his fellow believers, even wanting to kill them.140

Grebel's personal success during March and April 1525 in St. Gall was one of the high points of his life. His preaching was powerful and influenced hundreds of people. "By this time the movement had became a powerful popular movement, stronger than the 'evangelical' or 'Zwinglian' movement."141 Under the leadership of Ulimann Bolt of Lachen and others, Anabaptism began to spread throughout Switzerland. The work of Balthasar Hubmaier in Waldshut, the Brethren in Zollikon, the teaching of Felix Mantz, Andrew Castleberger, and George Blaurock in

\footnotetext{
${ }^{139} \mathrm{Egli}$, Aktensammlung, p. 141.

140 Egli, Aktensammlung, no. 692, pp. 309-310.

${ }^{141}$ Bender, Grebel, p. 144 .
} 
other areas such as Chur and Appenzell gained in popularity. In March 1525, Grebel arrived in St. Gall and stayed there two weeks. His preaching was powerful, and several hundred people came into the hall of the weavers' guild to hear him. 142

At this time the peasants revolted in Grüingen because of their application of the Reformation's teaching on the "priesthood of all believers," and their opposition to growing centralization of power over their free and autonomous political and economical rights.143 The peasants demanded the right to choose their pastors in their communities. This could show Anabaptist influence regarding free and independent churches, but Grebel and the majority of the Anabaptists were not involved nor were they interested in political uprisings. ${ }^{144}$ Nevertheless, Grebel and the Brethren were successful in every town and area where they preached, baptized, and applied the "priesthood of all believers" to the idea of the individual Christian life. This for them was spiritual in meaning, not social or political. But their message was also used in some areas such as Grüningen in support of the desire of the towns to

\footnotetext{
142 Von Muralt, Quellen, p. 70.

143 Bender, Grebel, p. 151.

${ }^{144}$ Bender, Grebel, p. 150.
} 
preserve their autonomous liberties against the centralizing powers of Zurich. The message of the Gospel was also applied to social and economic grievances such as the paying of burdensome taxes.145 This resulted in bitter disappointment for the towns, because they saw it as depriving them of their rights.

Most people, however, were influenced by the Brethrens' spiritual message. It was the Gospel and the idea of Christian freedom that formed the basis for individual freedom of conscience and the corporate freedoms of free and independent churches with "democratic" policies. If some communities applied this to socio-economic concerns, those concerns were not a part of the Brethren's emphasis. The idea of free churches coincided also with the strong protection of local liberties.

Because the Zurich council and Zwingli sought to suppress and destroy the Anabaptists and their influence, it is important to consider why the authorities considered them dangerous. It gives insights very clearly into the Anabaptist contribution to religious liberty and the ideals of the Reformation.

For the modern world the existence of separate "churches" or groups of Christians believing,

145Bender, Grebel, p. 148 . 
associating, and worshipping independently is regarded almost as an obvious human right, equally applicable to those of any faith or of none. The notion of uniformity of religion or compulsory attendance at church is as difficult for us to comprehend as compulsory attendance at school would have been for the sixteenth century. A community without a common ideology was at the mercy of one which was united. Religious differences practically meant civil war and this imperiled the very existence of the state. Zwingli's new opponents were dangerous for three reasons. First, they were deliberately and consciously disruptive. For Catholics, Lutherans, and Zwinglians there was but one comprehensive body of the faithful, one church. For the Anabaptists this was unacceptable. Secondly, these opponents turned his own weapon against him. They accepted sola scriptura and insisted that they were simply carrying his own teaching to its logical conclusions. Thirdly, they were exclusive politically as well as religiously. They refused to accept the normal obligations of citizenship, they claimed to be above the law and wanted to form self-governing "states" within states. Complete separation of church and state was not practicable anywhere in Europe before 1550. If this is what they wanted, they could not have succeeded, for the time was not yet ripe.146

Grebel's work in Grüningen was his greatest success.

For the period of four months, from June to October 8 , 1525, he was able to work exclusively in that area. He preached to the people, met and talked with pastors, preached at Hirslanden in August, and taught the Scripture.147 He endeavored to win the pastors as well as appealing to the common people. Despite success and popularity, the Anabaptists suffered persecution. The

\footnotetext{
140 Potter, Zwingli, pp. 170-171.

147 Von Muralt, Quellen, p. 109.
} 
councils of Zurich and other towns sought to suppress the movement. Many adherents of the dissident movement were ordered to appear before the council in Zurich, put in prison, and exiled.148 They were accused of slander or social agitation. ${ }^{149}$ some escaped and others recanted. At Hinwil on October 8, 1525, Grebel and the Brethren experienced the highlight of their ministry and popularity. The meeting took place in an open field attended by throngs of people from the general area. They preached, in spite of the fact that they had been ordered by the council not to hold a public assembly. 150 For the first time in public, the Anabaptists were defying the civil authority and doing so with the full support of a great crowd of people, which clearly showed they were on the side of the Anabaptists and not the civil authority--on the side of religious liberty, freedom of conscience, freedom of assembly, and freedom of speech. The Anabaptists may not yet have been consciously aware they were putting such ideas into action. It was not an agitating mob of social extremists, but rather the ordinary citizens supporting the truth and freedom preached by the leaders. ${ }^{151}$ This

\footnotetext{
${ }^{148}$ Von Muralt, Quellen, p. 113.

149 Bender, Grebel, p. 149.

150 Bender, Grebel, p. 153.

151Bender, Grebel, p. 153.
} 
showed their success and influence throughout the region. So strong was the support for the Anabaptist leaders that Burghermaster Jörg Berger of Grüningen had to secure assistance from other towns in order to end this assembly and arrest Grebel, Mantz, and Blaurock.152 They were sentenced on November 18, 1525. The court pronounced, "Konrad Grebel, Felix Mantz, and Jörg Blaurock are sentenced for their rebaptisms and other improper practices to imprisonment in the tower, sustained only by gruel, water, and bread. Their only contacts will be their assigned guards. This should last as long as God will allow and the judges deem appropriate."153

The proof of Grebel and the Brethren's purpose in Grüingen to preach the Gospel and challenge the people to live a truly biblical Christian life is found in the testimonies in the trial of November 1525.

Konrad Grebel's testimony, "he insists that children's baptism is of the devil, re-baptism is right, and Zwingli teaches wrong. He denies ever having preached they shouldn't obey the ruling authority. He never accused Zwingli of anything and didn't try to harm him in any way. He doesn't doubt that Löwen, Grossmann, and all others know children ought not be baptized, if they really want to tell the truth. ${ }^{154}$

152 Von Muralt, Quellen, p. 110.

$153 \mathrm{Egli}$, Aktensammlung, no. 863, p. 406.

${ }^{154} \mathrm{Egli}$, Aktensammlung, pp. 313-314. 
Grebel and the others were in prison for six months until after a second trial in March 1526, and on March 21, 1526, they escaped. Others scattered beyond Switzerland into South Germany and elsewhere. Grebel continued his traveling, but held no public meetings. He and Mantz worked during the summer of 1526 in Maienfeld, 155 before Mantz returned to Zurich; and Grebel continued until his death in August 1526 to accomplish the task of publishing his book on baptism, Taüfbuch. ${ }^{156}$

Hinwil, the arrest and trial were not an end, but the beginning of revolutionary Anabaptist ideas and the realization of those ideas in society. It was the beginning of the Anabaptist movement geographically outside Zurich and Switzerland. But Grebel's significance and that of the Swiss Brethren had begun in other places such as St. Gall, Appenzel, Grüningen, and Zollikon, and the infusion into society and history of their ideas was being acknowledged and challenged by those around them and those in authority. Before looking at the work in Zollikon as an example of their application of the ideas of religious freedom in practice, it is necessary to analyze Grebel's work and

\footnotetext{
155 Bender, Grebel, p. 161.

: bo Bender, Grebel, p. 162.
} 
the significance of what he and his associates put in motion in zurich and beyond.

Grebel and the first Anabaptists had a grasp of reality within their historical situation and a vision beyond it. Though much of it was unintentional, they saw clearly what needed to be done in the light of Scripture.157 In putting their understanding into practice, they became among the first existentialists. They could see the reality of the situation and its needs in the context in which they lived. Robert Friedmann comments, "One senses their sanity and inner soberness, also their absolute certainty of being on the right path and of being obedient to their God. One senses their assurance of being authentic disciples of Christ."158 Their existentialism was a positive one, a Biblical one, as Friedmann has indicated. It was one of hope and future, because God was the basis of their hope and truth. The word was power in the midst of life and death. A definition of Anabaptist examples of existential Christianity meant "the unity of faith and life," so that they showed neither despair nor anxiety even in the face of violent death. ${ }^{159}$ Grebel himself had

ib'Bender, Grebel, p. 109.

${ }^{258}$ Friedmann, Theology, p. 29.

isgriedmann, Theology, p. 31. 
a clear view of reality and of what he felt was needed to meet the challenge of that reality. He was not perfect, but he had a grasp of the political, social, and cultural issues of his time. A scholar, educated humanist, evangelical biblicist with a common sense view of the situation, a seeker and lover of truth, he could see where the inadequacies of the values put into motion by the Reformation lay. He wanted to carry the hallmark of the Reformation, the priesthood of all believers, to its complete fruition.

I will attempt to analyze how the Anabaptists and their ideas, especially those pertaining to religious liberty, were viewed by those among whom they were popular and those who were opposed to them. Also, I will discuss the meaning of their ideas and activities. Caution is due here not to read twentieth century perceptions back into the sixteenth century. But I think that the authorities' opposition to them has modern parallels and gives insights into common underlying factors.

There were several types of reactions against the Anabaptists. They were a sizable minority, and by 1540 they were nearly everywhere in Europe. Their ideas were influential and terrifying to the authorities and 
reformers alike for obvious reasons. Anabaptists were successful. They were popular and well received in the areas that were open to their ideas. "Between 1525 and 1550, this radical following of Christ swept like a prairie fire all over central Europe, and no persecution could intimidate the multitude of committed men and women and keep them from witnessing."160 I have already discussed why Zwingli regarded them as seditionists. They were a threat to the existing order. The tension between the original ideals and ethics of the Reformation which Luther and Zwingli both had wanted to achieve had fallen back into a compromise between those ideals and secularization of religion in partnership with the state. That tension had made it possible for the Anabaptists to come into existence and to push forward their program of free churches and individual freedom. In a sense, because of opposition to them, they restored and helped the Reformation achieve its goals through their impetus and influence, though much later in history.

From Zurich the movement spread with great swiftness and intensity; everywhere it attracted to itself all who were dissatisfied with the Reformation; the whole of central Europe was soon covered with a network of Anabaptist communities, loosely connected, who all practiced a strictly scriptural form of worship. The chief centers were in Augsburg, Moravia, Strassburg, and later on in

${ }^{160}$ Friedmann, Theology, p. 29. 
Friesland and the Netherlands. The whole movement was an early premature triumph of the sectarian principles of the Free Churches. ${ }^{161}$

Whereas it is understandable why the Reformers and authorities were afraid of their movement, threat to order, threat to the success of the Reformation, they created the possibility of civil war and socio-economic uprisings which were already occurring in many areas, and disobedience. It is easy to understand the fear of authorities, including 2 wingli. But when one reads Zwingli's vehement polemics against the Anabaptists, one is amazed. They are too extreme and inconsistent, filled with bitter exaggeration. They are slanderous. They are very general with no distinctions made between radical economic and eschatological groups and the Swiss Brethren.

Whithersoever they turn, all is woe; they overturn everything and change things into the worst condition possible. The hypocrisy of the Roman pope has been brought to light, now we must war with hypocrisy itself. They assail the magistrates in terrible fashion, they devote to destruction the ministers of the Gospel; on all sides they act like Alexander the false prophet, they promise I know not what salvation, these apostles of the devil. They revile the ministers, both of the church and the state. ${ }^{162}$

${ }^{26 i}$ Troeltsch, The Social Teaching of the Christian churches, 2 vols. (London: G. Allen and Unwin, 1931), p. 704 .

${ }^{162}$ Samuel M. Jackson, "Refutation of the Tricks of the Baptists," in Huldreich Zwingli, Selected Works of Huldreich Zwingli

(Philadelphia: University of Pennsylvania Press, 1972), pp. 136-37. 
The question that comes to mind is: Whom is it that Zwingli is talking about? If it is the Swiss Brethren, then one can only conclude that the polemics are a deliberate effort to make sure that no one reads or hears about their views. The fear of insurrection? Yes, but much more. Was he speaking of Grebel? If so, it is obvious he wanted to discredit him. He knew Grebel, for they had been on most intimate terms as scholars, biblicists, and theologians. They had discussed faith, Iife, everything together. Zwingli knew Grebel had been born of his theology and his Reformation. He knew his balanced view of obedience to government and law.

It is to be recalled that Grebel and Zwingli had come out of the same cultural heritage. My point for bringing this factor up again is to show that the founder and each one of the major leaders of the Anabaptist movement such as Michael Sattler and Balthasar Hubmaier, as well as the transitional figures such as Pilgram Marpeck and organizers like Menno Simons, were people from the mainstream of society originally. They were of the upper classes of society in that they were either patricians, theologians, civil servants, clergymen, or teachers. They were not from the lower social levels of society that comprised discontents. Most were common, 
but respectable working people. Nor were they a conglomerate of fanatics, extremists, disruptive visionaries, rioters, and vagabonds that were common in that day. The groups and churches that they formed reflected the biblical and respectable aspects of society. Those biblical and respectable virtues that they upheld characterized their movement as the "mainline" Anabaptist movement that would continue into the late sixteenth and early seventeenth centuries. Why, then, the polemics against Grebel and the Anabaptists? I believe it to be personal bitterness and the deepest fear of their insistence on a separated church, but even more, a fear of the promoting and acting upon individual conscience. Their ideas brought a new focus and attitude toward the individual which had far-reaching implications even then. Their ideas were that biblical existentialism of the individual took the priesthood of all believers beyond its already known possibilities. In fact, Anabaptism was the earliest champion of liberty of conscience in the face of the gross intolerance of the established churches everywhere. "Christ's people are a free, unforced, and uncompelled people, who receive Christ with desire and a willing heart," wrote Kilian Auerbacher of Morovia to Martin Bucer in 1534. Hence 
"faith is not to be compelled but it is to be accepted as a free gift of God."163 Zwingli and city authorities could not help but understand this at least to a certain extent, but they were terrified of their ideas. These ideas of separation of church and state, and of individual conscience and independence of thought, might create a revolution in society and transform it. Whether this was Zwingli's fear or not is speculative, but the Anabaptists demanded this kind of thinking because of their insistence on an "existential" biblicalism and commitment to that principle. For this reason they applied their ideas to the establishment of the first Anabaptist church in history, the Zollikon church.

V.

One of the few positive words that Zwingli had to say about the Anabaptists was his comment about the Zollikon church: "They have gone out from us, for they were not of us. Yet I may add this one item: there is a small church at Zollikon where the catabaptists set up their teaching under inauspicious beginnings. This church, though small, is admirable in its constancy."164 Grebel had laid the foundation at Zollikon, as he was

\footnotetext{
103 Friedmann, Anabaptism, p. 133.

164 Jackson, Selected Works, p. 137.
} 
there briefly during the week following the historic meeting on January 21, 1525, when the movement was born. He visited the brethren there, officiating at a communion service at the home of Jacob Hottinger, and then went on to Schaffhausen. ${ }^{165}$ "Conrad Grebel and Felix Mantz every morning and every evening went to several houses. Other than that groups gathered everywhere from Balgrist on and in other areas."166 It was Felix Mantz, George (Jorg) Blaurock, Johannes Brötli, and Henri and Jacob Hottinger that would lead the work in Zollikon.

The Zollikon church was established between January 21 and 29, 1525, in the town of Zollikon, about five miles from Zurich. It was the first practical application of religious liberty and freedom of conscience in a "gathered" or congregational way. It was the first separatist church established by the Anabaptists, and possibly the first separatist or free church of early modern history. It was certainly an example of the type of social religious liberty that has been presented earlier in the thesis. These are the four kinds of religious freedom: liberty of conscience, liberty of expression, liberty of association, and

165 Von Muralt, Quellen, no. 29, p. 38. ${ }^{166}$ Von Muralt, Quellen, p. 3. 
institutional freedoms. ${ }^{167}$ The Zollikon church was composed of between sixty to eighty members, both men and women. The majority were farmers or craftsmen. These farmers were not poor but owned their own lands. They made their living from their land but supplemented the small-scale farming by working as laborers or at a trade. Some were shopkeepers, journeymen, or artisans. They were similar to the yeomen of England. ${ }^{168}$

The marks of the Zollikon church were apostolic simplicity, revival impetus, and evangelism. Within a broader framework, the Anabaptist commitment to discipleship and faithfulness to scripture, and their principles of liberty of conscience and the idea of a free, self-governed church independent of the state, characterized the work there. "They placed repentance before baptism, they baptized adults, they emphasized that baptism also means power for a new life, and they rejected the state church."169

To understand what is meant by apostolic simplicity it is necessary to look at what the Anabaptists meant by this term as well as by revival impetus and evangelism. Even though it was Grebel's original intention to have a

${ }^{167}$ Carrillo de Albornoz, Basis, p. 26.

${ }^{168}$ Blanke, Brothers in Christ, The History of the Oldest Anabaptist Congregation, Zollikon near Zurich, Switzerland (Pennsylvania: n.p., 1961), p. 42 .

${ }^{169}$ Blanke, Brothers in Christ, p. 39. 
united church of believers only, the rejection of his plan by Zwingli had forced him to organize a separatist church. When this occurred, the Brethren saw themselves as obeying the New Testament teaching on what the church was. That church was of apostolic simplicity, that is, it conformed to the simple forms of worship that the New Testament Christians had practiced. That meant simple observances of the Lord's Supper where each person breaks a piece of bread and each person drinks a small glass of wine. There were no vestments, robes, candles, or other sacramentals.

Revival impetus meant the population of the town was caught up in a renewed spirituality that was the whole topic of conversation and life. Sometimes it expressed itself in emotional remorse for sin and the request for spiritual renewal. At times it could be very meditative. It resulted in evangelism that involved members of the populace who had experienced "revival" often going door to door and sharing their faith, or preaching on street corners. Mainly, revival meant the majority of the people of the community as a whole becoming repentant and turning to God. Apostolic simplicity was exemplified by the spontaneous adult baptisms immediately upon conversion such as that of Fridli Schumacher by Johannes 
Brötli at a well in Hirslanden while they were traveling.170 The Lord's Supper was shared by simple laymen breaking a communal loaf of bread into individual pieces and drinking the wine as a solemn fellowship mea 1.171

Heinrich Thoman said on January 25 he went to Rudi Thoman's house after dinner. There was a crowd gathered, they began reading the scriptures. Among them Blaurock took some bread and broke it to pieces, he also had a cup with wine. After he was done, he said, whoever wanted to enter this union with them should eat of this bread. Everyone took a piece of the bread. 172

This was a radical and revolutionary departure from the state church, and a return to New Testament practice. ${ }^{173}$ The lay meetings not only consisted of fellowship and observance, but Bible studies and discussions of spiritual and theological matters. They were meetings where the believers shared some of their innermost struggles and convictions of sin and desire to live a faithful Christian life.174

The growth of the zollikon church was first spiritual and inward, then outward and social as it became a powerful source of evangelism. Baptism became

${ }^{170} \mathrm{Blanke}$ Brothers in Christ, p. 22

${ }^{171}$ Von Muralt, Quellen, no. 29, p. 38.

172 Von Muralt, Quellen, no. 29, p. 38.

${ }^{173}$ Acts 8:36-39, New American Standard Bible (Chicago: Moody Press, 1976). All future citations in this thesis from the Bible are from this edition.

${ }^{174}$ Von Muralt, Quellen, no. 31, p. 40. 
the act of obedience for all who had found new life through their faith in God.

When we seek a caption for the inner processes of these eight days, the concept "revival movement" presents itself. We thereby understand the sudden occurrence of a religious awakening, in which not just a few individuals but a considerable number are gripped by a personal christian disposition to repentance and breakthrough to the joy of salvation. ${ }^{175}$

This revival shows the Reformation's return to New

Testament Christianity, but the Anabaptists brought it to its full implications.

Here we meet the reformational understanding of sin, and that not just as abstract theory but as personal experience. ${ }^{176}$ Their insistence on obedience to Scripture and to God before man was for them the motivating factor in their separatism. When a farmer, Lienhard Bleuler, was asked by his interrogators at his trial later, after many of his coreligionists had been put in prison, if he would renounce his Anabaptism, he answered, "He is God's servant and no longer has might and power over himself, and has enrolled under the Captain Jesus Christ and will go to death with the same, and what He commands and enjoins him, he will obey and do it. ${ }^{177}$

Persecution and imprisonment were inevitable in zollikon. As a result of their preaching and practice of a separating church, the leaders and many followers were put into prison--Mantz and Blaurock in the Zurich state

$175 \mathrm{Blanke}$, Brothers in Christ, p. 32.

176 Blanke, Brothers in Christ, p. 33.

${ }^{177}$ Von Muralt, Quellen, no. 33, p. 43. 
prison, and Wellenberg tower in the Limmat, the others in the Augustinian monastery in Zurich. ${ }^{178}$ They were held from January 30 to February 8, 1525. They were questioned and attempts made to re-convert them. They were released on February 8 on an "oath of peace," promising not to preach or baptize adults. This meant giving up the Anabaptist church. The council then granted them the "freedom" to meet among themselves, but only in groups of three or four persons and only for joint Bible reading and Bible discussion but not for baptism and preaching. ${ }^{179}$

The majority of the Brethren agreed to not preach or baptize anymore. This meant they would, at least officially, recognize the infant baptism of the church and abstain from any further rebaptism in Zollikon. "The men in writing gave an oath of truce about themselves and swore on it. And the persons listed below undersigned to it: Marx Bosshart, Lienhart Fessli, Rudolf Breitiner, Cuny Hottinger, and others of the brethren."180 This concession to the council grieved the leaders, Brötli, Blaurock, and Mantz, and they resolved to bring new life into the Zollikon church.

\footnotetext{
${ }^{178}$ Von Muralt, Quellen, no. 37. 179 Von Muralt, Quellen, no. 76, p. 83. 180 Von Muralt, Quellen, no. 76, p. 83.
} 
The ways in which they did this was to be in contact with one another. Since they could not baptize or preach, they could read the Bible and minister to one another and others as they needed. They read the Scripture to many who could not read. The records of the testimonies before the Council later in the year (June 1525), as a result of Anabaptist activities in the area, sheds light on the inner situation of the Brethren in February when they were released from the Zollikon prison.

Rutschmann said, according to the verdict of my lords, given by them when they were in the

"Augustinern" [prison] that from now on they weren't allowed to baptize, but they could still visit each other and read the scriptures, as well as teach each other and instruct each other in the Word of God, the more they do it the better. He insists that he never acted against this verdict, but lived according to it and only read the Scriptures, etc. Furthermore, the people of Wassberg sent to them in Zollikon asking them to send two of them back with them to read to them. So the brothers in Zollikon sent him and Felix Kienart to them. All they did was read to them. They were asked by the people of Nenikon for the same thing, and again he and Felix Kienarb were sent there. And there they did the same, just read the scriptures to them. When they went to Mur, some women came and begged them to read to them. More men and women came and begged them, so they did read to them. ${ }^{181}$

These activities showed the continued solidarity within the movement and the influence of their ministry even

\footnotetext{
${ }^{181}$ Von Muralt, Quellen, no. 76, pp. 82-83.
} 
without preaching. They all began to minister anew to the church, but the outstanding influence was the dynamic evangelizing of Blaurock, who began baptizing and holding revival meetings at the home of Hans Murer in Gstad. ${ }^{182}$ on Sunday, February 26,'1525, Blaurock was again active in zollikon. Sunday morning he preached and in the afternoon held a second meeting. This meeting is significant for several reasons. Not only was a major leader once again evangelizing and thereby violating the verdict against the Brethren, but the character of the meeting shows the idea of spiritual equality of women within the movement. It shows that women made their own decisions and were considered equals in ministry. At the meeting eight women rose, gave testimonies of their faith, and expressed a desire to be baptized. "Heinrich Wust said his wife and his people had told him how on Eebruary 26 Blaurock had given two sermons in Zollikon. There, people say, he had baptized about eight women. Jacob Vnholzen's wife, Trini Hottinger, Jörg Schaden's wife, Rusch Hottinger's wife, and others."183 The wives of the husbands who had been in prison and who were baptized were already members of the church. These women and girls came from Anabaptist families and did not

182 Von Muralt, Quellen, no. 48, p. 58.
183 Von Muralt, Quellen, no. 48, p. 58. 
reflect a new increase in the Zollikon church. "These women would certainly never have decided to be baptized if they had not had the support of their husbands and fathers."184 An earlier incident of women being baptized was in the first week of February. "Rudolph Hottinger said that he had baptized a young woman who asked him with tears in her eyes to baptize her. And because he is a servant of God, he said, he would never order someone to be baptized, but if someone came to him and desired with diligence and seriousness of heart to be baptized, then he would baptize that person."185 They continued to baptize, hold communion services, often in the open or in the church building at Zollikon from March 8 to 15, and the result was an increase of eighty persons in the church. The increased dynamic of evangelization reflected the Anabaptist view that if God gave them opportunities to carry out their concept of mission as they saw it, they could only obey.

A communion service in the open in broad daylight, rebaptisms in the church on Sunday; these show that the Anabaptists in Zollikon had lost all reticence. They took the leadership of their fellowship into their own hands. They held meetings embracing more than the allowed four persons in which they not only read the Bible but also preached. This is the "priesthood of all believers" which the new Testament and the Reformation proclaimed as the

${ }^{184} \mathrm{Blanke}$, Brothers in Christ, p. 52. 185 Von Muralt, Quellen, no. 33, p. 43. 
ideal. Now they summoned courage to make use of the right of the lay priesthood. ${ }^{186}$

Many of the members of Zollikon came from the surrounding villages of Hönegg and Küsnacht. The work at Hönegg had been prepared by the former pastor there, Simon Stumpf. ${ }^{187}$

As the church continued its work of preaching, baptizing, and observing the Lord's Supper in these other areas, more numbers were added.

Jörg Schad of Zollikon confessed that he baptized forty people the previous Sunday, March 12; some from Zollikon, some from Hönegg and Küssnacht, whoever wanted to be baptized. He couldn't name all of them, only a few; Kunraten Napfer and his wife, Bluwler's daughter, Anli and Frenli Schuchmacher, Wysshans Hottinger's wife, Vli Gattiker and his wife, Jos Schwaben's wife of Ittschnach, and mayor Blüler's wife. They celebrated the Lord's Supper the way God commanded it to be celebrated. Claus Strowli's wife begged him in the name of God to baptize her: He could not deny her request. ${ }^{188}$

Often these meetings took place in an open field such as the one held by the lake in the orchard of Hans Murer. ${ }^{189}$ The following week more persons were added to the church by Hans Bichter, about thirty in all.190 This increase was significant because most of the people were from

\footnotetext{
${ }^{186} \mathrm{Bl}$ anke, Brothers in Christ, p. 53. ${ }^{187}$ Von Muralt, Quellen, no. 55, p. 63. ${ }^{188}$ Von Muralt, Quellen, no. 55, p. 63. 189 Blanke, Brothers in Christ, p. 53. 190 Blanke, Brothers in Christ, p. 53.
} 
outside zollikon as has been said, and the majority of the newer members were women. ${ }^{191}$

Renewed imprisonment followed this upswing of growth. The authorities accused the leaders of the Zollikon church of breaking their promise, but the brethren reminded them of their position: "What we promised in the Augustinian prison, namely, that we would stop, we have kept. We stood still until God bade us to do otherwise."192 This had resulted in their arrest, cross-examinations and attempts to reconvert them on the basis of scripture. The councilors had to be impressed by the biblical knowledge of these ordinary laymen. "These Anabaptists were not spiritualists who depended on personal illumination, but they were biblicists, who found their guidance in the Bible. They had been instructed concerning baptism by the Word of God. These men from Zollikon and Zurich wanted to be considered responsible Christians and Bible readers."193 Nevertheless, they were prohibited from baptizing and preaching and most promised to do so, with only four who stood by their confessions and principles.194 They were released on March 25 with a warning that a relapse would

\footnotetext{
${ }^{191}$ Blanke, Brothers in Christ, p. 54.

192Blanke, Brothers in Christ, no. 54, pp. 61-63.

193 Blanke, Brothers in Christ, p. 58.

${ }^{194}$ Blanke, Brothers in Christ, no. 64, p. 75.
} 
bring banishment. ${ }^{195}$ This was the official end of the church.

The church and its leaders in zollikon, though prohibited from existing as a separate church, did not stop the work to which they felt God had called them. They continued with their Bible meetings. They activated an outreach mission or a "reduced program" of sending Bible readers to Wassberg and Nänikon on the request of the Brothers in that area. "From this we see that the brotherhood is still together. It does not sit in idleness, but wants to contribute what it can toward satisfying the hunger for the Bible; and therefore when asked, it sends into the surrounding villages farmers who can read."196 The Zollikon church simply transferred its evangelistic work elsewhere. But in Zollikon itself the church continued "underground."

Rutsch Hottinger accompanied Rudolph Rutschmann and Felix Kienart to Nenikon. While they were on their way, they were asked to come into a house. When they did they were asked to read from the scriptures for the people of that house. But they didn't baptize anyone there. Later, on their way home, some women asked them to read to them from the Scriptures. He read to them a chapter about the love of God, because love for one's neighbor is the first thing they should know about. ${ }^{197}$

${ }^{195}$ Blanke, Brothers in Christ, p. 59. 196Blanke, Brothers in Christ, p. 67. ${ }^{197}$ Von Muralt, Quellen, no. 76, p. 83. 
The continued effort to satisfy the demand for the Bible is reflected in this underground effort. When the readers were arrested they gave as to their reasons for doing so: "to go to each other to read and also to instruct each other and teach the Word of God. We have done nothing else other than this in zollikon, and because the request came to our church from outside, our church went outside only as readers, not as baptizing preachers."198 The Zollikon church was forced to disband, but the members continued to meet whenever possible. The Zurich council could not tolerate a separate church, especially one that held private gatherings. By August 1525, Jacob Hottinger, the senior leader of the Zollikon group, received an order that he and the others should not meet together, but go to the official church and hear the word of God. The obvious coercion and suppression of the freedom of conscience and the free church is reflected in the reply of Jacob Hottinger at his trial before the council. "The letter had demanded that he, Hottinger, and others should go to church instead of banding together. Hottinger then claimed that the truth of God's word wasn't being taught at church. He then said that he always volunteered to obey, just like a

${ }^{198}$ Von Muralt, quellen, no. 76, pp. 82-83. 
Christian should, the commandments of my lords, which he still intends to do. But he hopes that my lords won't force him to attend church."199 During this time the Zollikon brothers held a meeting at the home of Heini Hottinger in order to make a final decision concerning giving up baptizing, living a Christian life together, and being obedient to the council. They decided to give up the idea of an "underground" church. But many of them went elsewhere and were to continue to spread the idea of a free church. The idea of a free church and freedom from coercion is reflected in Hottinger's revolutionary words at his trial,

On the issue of the ruling authority, what it is and if they should deal with the word of God, he said, "My lords and their preachers ascribe more to the ruling authority than it is entitled to. Then it would be the right of the ruling authority to bring the Word of God under its power, but the Word of God on the contrary is free. He asks my lords to not press him to give up his opinion and faith, but to let him keep it. My lords must not explain much about how they deal with the Word of God, as long as it is just and acceptable before christ. And isn't that the highest goal, to follow Christ?200

At this point it is important to look at excerpts from a Swiss Brethren tract as to the reasons why they had insisted on their own independent gatherings and why they refused to go to the state church. The tract was

${ }^{199}$ Von Muralt, Quellen, no. 101, p. 103.

200Von Muralt, Quellen, no. 101, pp. 102-103. 
printed by Bullinger in 1532 as a means of attempting to sway public opinion against the Anabaptists at that time. It may not directly refer to zollikon, but the reasons given reflect those activities that the Zollikon Brethren also attested to and had influenced other fellowships to engage in throughout the early period, creating a problem for the authorities.

Here follows a resume of the above-named reasons why we do not attend their preaching; one reason is that the evangelical preachers at first taught from the word of God, the evangelical, Christian freedom of faith, matters of faith, against the rulers and constrainers of one's faith, and the authorities, pope, emperor, prince, and others, have no right to exercise power or command concerning faith, should, conscience and that men are not under obligation to obey them, and similarly whose earlier teaching of Christian freedom is founded and witnessed in these gospel passages: Matt. 17, John 8, I Cor. 6, 10, II Cor. 3, I Tim. 1. From which Christian teaching and the word of God concerning evangelical liberty, they now suppress and transgress. They force and compel men, they persecute, kill, exile, and afflict, by which they become shedders of innocent blood. The Christian Gospel neither desires nor teaches that any one be compelled with force to its teaching, preaching, fellowship, nor regarding any other matters of faith or the soul, but teaches the opposite, that no one shall be compelled thereto, and cursed be what is taught otherwise. They also do not hear our words as the word of God. This is also why they will not permit us to speak in their churches, fearing we might deceive them. . . Another reason is because they are no established, separate church of God, nor body of Christ, as Spirit of love, baptized of Christ. For Christ has 
commanded this only to his followers and disciples, who are separated from the world.201

These clear statements reflect their actions as being the result of conscience according to their understanding of the Bible and by so doing creating a "separatism" they felt absolutely justified in carrying out. In this the seeds of their ideas continued to be planted in society. In Zollikon the Brethren had ceased baptizing and agreed to simply live the Christian life quietly and be obedient to the council. They continued to influence others by their exemplary lives. Also, in Grüningen and elsewhere they were reading the Bible, baptizing, and gathering together, though under persecution.202

Jacob Hottinger the senior leader of Zollikon had caught the vision of what the Anabaptists had brought into being. "Before his eyes stood in particular brilliance the picture of what the early Anabaptist movement had sought to achieve. A great new concept, it was the idea of personal religious freedom and the free church. ${ }^{203}$ Hottinger expressed this in his own words in August 1525: "For it is not given to any government to dispose over God's word with worldly means of force; is

201 Shem Peachy and Paul Peachey, "Answer of some who are called Anabaptists, why They do not attend the Churches. A Swiss Brethren Tract," Mennonite Quarterly Review (January, 1971), 14, 15, 17, 20. This is an awkward translation by Peachy. I did not have access to the original.

202 Von Muralt, Quellen, no. 105.

${ }^{203}$ Blanke, Brothers in Christ, pp. 70-71. 
not the Word of God free?"204 By making this demand he was advocating freedom for those who chose not to recognize the state church.

He demanded the human right of individual liberty of conscience and of voluntary formation of the church; the village of Zollikon on Lake Zurich was the place where, within Protestant history, the first attempt was made to bring into being a Christian community independent of the state ... There will always be a need for men who, unconfused by the spirit of the age, set out for new goals and strive toward a new dawn. The Zollikon "Brothers in Christ" were such a vanguard. Their daring has not been in vain. In gratitude we bow before them today. ${ }^{205}$

The Zollikon church had been dissolved, but the idea remained.

The idea of religious liberty as it pertains to freedom of conscience and its external or social aspect of freedom of expression and assembly can be seen in the obvious ways in which the Anabaptists applied and promoted it in Zollikon. The idea itself as analyzed earlier by Carrillo de Albornoz, Bates, and others, can be detected in Zollikon and in the entire early movement. The church at Zollikon is certainly an example of the kind of social religious liberty that Carrillo de Albornoz describes in his study and is the result of the kind of freedom of conscience that is activated externally in connection with social religious liberties.

${ }^{204}$ Von Muralt, Quellen, 101, p. 71.

${ }^{205} \mathrm{Bl}$ anke, Brothers in Christ, p. 71. 
We would call the freedom of religious expression, freedom of religious association, and the corporate and institutional religious freedom, mixed religious freedoms, in the sense that these three types of religious liberty presuppose not only "pure" religious freedom itself (liberty of conscience), but also the fundamental human rights of expression, association and of corporate freedom. ${ }^{206}$

The Zollikon Church realized each one of these types of religious liberty, usually simultaneously, such as the individual convictions of conscience concerning sin or the commitment of their faith into their lives, their small prayer groups, and the larger association of the church body in public or private. Bates makes an observation that could be applied to Zollikon:

Surely there can be no morality or character without choice; there could be only subjection and tutelage. The individual needs for himself to seek the right end, where other ends are possible. Social, educational, and religious factors enter into the development of conscience, indeed are requisite to that development. But the conscience is the center of decision in which the free personality constitutes a synthesis of inner and outer moments. 207

Lecler interprets the Anabaptists as the first movement in early modern times to found churches based on the principle of separation of church and state and to perpetuate that idea by their commitment to it.

What stands out among the moderate Anabaptists is their doctrine on the nature of the Church and on

${ }^{206}$ Carrillo de Albornoz, Basis, p. 24.

${ }^{207}$ Bates, Religious Liberty, p. 296. 
the relations between church and state. They built their community on the model of a sect and so were led to affirm for all practical purposes the separation of church and state; in such a system freedom of conscience is secured by the very fact of this separation. And so, for the first time, the separatist point of view on the issue of tolerance was given expression by the sects that proclaimed the complete severance of the spiritual and the temporal. 208

Therefore, most of the primary characteristics of religious liberty are relevant to zollikon. But how could they influence society toward their ideals of freedom of conscience or of a free church led by laymen when they were prohibited as an organization after 1525 in Zollikon itself?

This is not an easy question to answer because ideas in history do not develop chronologically. The Zollikon Church had agreed to stop being a church in so far as preaching, baptisms, and missions were concerned. But they continued to be faithful to their principles of "purity," applying the unity of faith in all areas of their lives. This, for them, reflected the lordship of Christ in everything, not just what outsiders considered to be the "religious" areas of life. Their Christian lives were not associated only with "going to church" or being a church, or even with being moral and lawabiding.209 It meant practicing tolerance toward

\footnotetext{
Wecler, Toleration, vol. I, pp. 215-216.

"Friedmann, Anabaptism, p. 28.
} 
neighbors even though the same was not returned. It meant suffering ridicule from society with patience and even joy. It meant being people of love because of God's love and grace in their lives, and their spiritual freedom to choose to be His disciples. Because they had experienced the love of their God, they manifested this love at every opportunity. This love reflected the deep spirituality in their lives and their willingness to accept persecution or even martyrdom for their principles. Their lives having been so exemplary, often there were reactions from the general population whenever any of their number were unjustly arrested, as with the second arrest and imprisonment in Zurich in March 1525, when a small crowd of citizens came out of their shops and homes and protested the arrest of several of the Brethren. "In Zurich people lined the streets, some shouting at the officers for suppressing freedom of faith."210 It has already been mentioned that after the Zollikon Church was forced to cease its work, several of the brethren went to areas outside of Zollikon and Switzerland and eventually into southern Germany and Austria. In addition to geographic spread, the influence of the Zollikon Anabaptists spread in a number of other

\footnotetext{
210 Myron S. Augsburger, Pilgrim Aflame (Scottdale, Pennsylvania: Herald Press, 1977), p. 107.
} 
ways. Some of those ways were the conversions of key local people such as the wife of the Zollikon bailiff, Hans wert, during and after the ministry at Zollikon.211 Another example is Jacob Hottinger the younger, the watchman of the city. He was an asset to the movement as he had regarded Anabaptism with skepticism, thinking they were extremists and enthusiasts, but had changed his attitude upon seeing the demonstrative love in their lives. "Jacob's conversion startled his sophisticated friends. One by one, he spoke to them about his new life in Christ. Within a few days seven of his circle experienced a spiritual birth."212 An Anabaptist who continued to be an influence because of the dramatic change in his life after his conversion was Jorg Schad, a farmer. "He had led a notoriously profligate life, but a few weeks earlier he had been soundly converted. The change in Schad was the talk of Zollikon."213 what was uppermost in the lives and doctrine of the Anabaptists was living spirituality, discipleship, missions and Christian freedom, and its result in a free church, which were the basis for freedom of conscience.

VI.

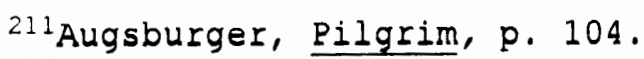

212Augsburger, Pilgrim, pp. 103-104.

213 Augsburger, Pilgrim, p. 100. 
The Anabaptists, like most of society and especially those involved in the movement of the Reformation, were aware that they lived in an era of change. The ferments of the day were signs that theirs was an age of transition. People were becoming individuals. They were thinking for themselves, taking responsibility for their own actions, such as monks and nuns leaving the monasteries under the influence of Luther's preaching in the "Freedom of the Christian".214 They sought to follow their convictions and experience new freedom, and in the spiritual sphere that meant seeking truth and meaning as individuals, not just as members of a hierarchical system of society. The printing press had made reading accessible to the common man as literacy became more prevalent. People hungered for knowledge. As the Bible was translated into the vernacular languages, demand for it grew. Because of these important developments, the teachings of the Anabaptists would appeal to all classes, but especially to the common people, because the writings of leaders such as Michael Sattler and Balthasar Hubmaier were being read after 1525, just as Luther's early teachings on justification and priesthood of all believers had been and continued to be.

${ }^{214}$ Dillenberger, Martin Luther, p. 42. 
It was only natural that Anabaptist practices of "freedom of conscience" would be taken to their logical conclusions and result in a free church. Anabaptist practices gave the growing ideas of the individual a more radical dimension. People received their nonproselytizing witness with interest or sympathy because of the new awareness of the individual. The common man and others were influenced by how the Anabaptist dealt with persecution and often reacted against what they felt was injustice, such as when the Brethren in Horb in 1527 were arrested; the townspeople erupted in protests lasting for days. "Local citizens stepped out of the houses to watch. A few called out some word of abuse, but most derided the officers for their violation of freedom in the arrest of good citizens. Outside the prison a crowd was gathering. Angry citizens were asking the bailiff to explain his action."215 Though a "minority," it was the quality rather than the quantity of their contacts that caused the Anabaptists to become one of the most influential of all the reform movements of the time.

of all the Anabaptist leaders, none was held in as high esteem by friends and enemies alike than Michael

${ }^{215}$ Augsburger, Pilgrim, p. 106. 
Sattler. Sattler was born around 1490 in Stauffen in the Breisgau area of Southwest Germany. He served as a prior in the Benedictine monastery of St. Peter's northeast of Freiburg and was second only to the abbot in responsibility for the training of novice monks. In 1523 he found himself challenged by Luther's doctrines concerning justification by faith and the freedom of the Christian, which led him to leave the monastery and in time become an Anabaptist. He married a beguine, a member of a group of women and who were not bound by vows, but who served the convent. Together they became servants and leaders in the Anabaptist movement in Breisgau, Zurich, Zollikon, Schaffhausen, württemberg, Strasbourg, Horb, and Rottenburg. He served in Zollikon briefly, was at the "disputation" at Zurich November 6-8, 1525,216 then was imprisoned briefly, and expelled from Zurich territory on November 18.217 He was a pastor in the town of Horb and imprisoned there and in Rottenburg in the spring of 1527, where after an illegal trial, ${ }^{218}$ he was tortured and burned at the stake on May 20, 1527. His wife was drowned two days later. The impact of his

\footnotetext{
216 Von Muralt, Quellen, No. 118, p. 116.

217 Von Muralt, Quellen, No. 133, p. 136.

$218 \mathrm{John} \mathrm{H}$. Yoder, The Legacy of Michael Sattler (Scottdale, Pennsylvania: Herald Press, 1973), p. 66.
} 
martyrdom shocked leaders of the Reformation and caused

the Anabaptist movement to spread even further.

The echo of the execution of Sattler was rapid and widespread. The action was not made more acceptable by the leading role which was played in the trial by the representatives of the tyrannical Ensisheim administration of the Austrian Empire. The almost immediate circulation of the report in several printed versions testified to the wide extent of popular interest in this martyrdom. The special place that this execution holds in the memory of early Anabaptism is largely a testimony to the personal stature which he had acquired, well beyond the confines of the particular congregations he served, as the spiritual pillar of the Swiss Brethren movement. ${ }^{219}$

The influence and vision of his leadership gave the free church movement a new and stable foundation, and an awareness of its historic and revolutionary purpose. As the author of the Schleitheim Confession, Michael sattler became the bridge between the early Anabaptist period and the later Anabaptist leaders such as Pilgram Marpeck and Menno Simons.

That Anabaptism survived as a viable movement with visible structures from the naive beginnings in Zurich in the mid $1520 \mathrm{~s}$ to the time of the synthesizers of the 1540s, was the work of Michael Sattler more than any other one person and was the effect of the Seven Articles of Schleitheim, more than any other one single cause. ${ }^{220}$

\footnotetext{
219 Yoder, Legacy, p. 67.

320Yoder, Legacy, p. 7.
} 
Sattler's consolidation of Anabaptist views of the church and organizations was the result of a life of commitment, love, and a passion for freedom.

When Michael Sattler left St. Peter's Monastery, he walked into a new life that had begun with a deep search for a real and living faith. He found it in a true and personal trust in christ instead of the trained disciplines of the monastery and the teachings of the Roman Church which had given him a sense of "security" in following its regimen of merit. Hearing the Protestant preachers in the area of Breisgau had caused him to search the Scriptures; he discovered justification by faith for himself. "Justification by faith had now taken on a very personal meaning. The matter was not just a conflict between Luther and the pope; it was an issue of faith. Many who had taken up the doctrine of Luther were testifying to an assurance of peace which, instead of being frightening, was forceful."221 He then finally had a sense of spiritual freedom. He also continued his quest and growth toward a life of discipleship beyond the ordinary. The lordship of Christ became vital to Sattler in his sense of purpose and desire to become involved in whatever God had for him to do. "He felt the inner surge

\footnotetext{
$\therefore$ Augsburger, Pilgrim, p. 36.
} 
of a new freedom, not the freedom from St. Peter's, but the freedom of a man who follows conviction, who is committed to a cause greater than himself. ${ }^{222}$

While learning about the Anabaptists through the influence of Simon stumpf and Wilhelm Reublin, 223 who were priests in Honegg and Wytikon and who had begun to preach the Gospel in their areas, sattler worked as a teacher in Schaffhausen after his marriage in the fall of 1523.224 Stumpf and Reublin had been part of Zwingli's inner circle who supported Grebel in his disagreement with Zwingli over the latter's refusing to abolish the Mass. Sattler had already achieved a reputation as a Bible scholar and teacher in the area of Schaffhausen. "Various Bible study groups met in homes in the area including their own. Michael's knowledge of the scriptures made him a prominent figure in this movement."225 He had also heard the preaching of the Protestant reformers, such as Sebastian Hofmeister. "Hofmeister had stimulated the populace to freedom of thought to acceptance of the new doctrine of Luther; but his association with Zwingli added fuel to the fire."226 For Sattler, it was not only freedom, but the necessity

222 Augsburger, Pilgrim, p. 56. 223Augsburger, Pilgrim, pp. 69, 76.

${ }^{224}$ Augsburger, Pilgrim, p. 68. 225 Augsburger, Pilgrim, p. 68 . ${ }^{226}$ Augsburger, Pilgrim, p. 66. 
of personal faith and fidelity to scripture and its authority that must be the basis of freedom. The reform preachers had true faith, but they were compromising Scripture; sattler had reached the same conclusions as Grebel. "He conversed at length with Dr. Hofmeister as to whether the break with Rome was being carried far enough. He was disappointed with Hofmeister's plan to maintain many of the former state church practices. The new movement was failing to provide individuals with a committed personal faith."227 Michael sattler, with Martin Luther, wanted to see the Bible placed in the hands of all the people. He was convinced that life in Christ meant life on a level superior to that prescribed by the religion so prevalent in the land. "The New Testament," he taught in his classes, "expresses life in Christ as a life of relationship by faith, a life in the Spirit. ${ }^{228}$ Sattler's conviction was that freedom must come from a spiritual relationship and a walk of discipleship that turned the unity of faith and life into a basis for the freedom to act on one's convictions. For him that meant evangelizing and teaching, which must result in a free church requiring religious freedom. "The conviction was clear that the true church found its 
pattern in the acts of the Apostles, and his calling was to help develop such a church again. 229

Sattler and his wife committed themselves to the cause of continuing the work of a free church outside the Zollikon area after the final imprisonment of the Brethren.230 Prior to that he had been active in preaching in the Zollikon area, traveling to such towns as Honegg. "Michael engaged in Bible teaching and preached to small but eager audiences. The Brethren were in hopes that the whole zollikon community would turn to Anabaptist belief. They met in homes or when larger groups gathered, in a Bauernhof or in the open in some secluded area."231 Because of the recurring imprisonments and increasing dangers to the church in zollikon, which would result in its disbandment, sattler urged several leaders to work elsewhere, such as Felix Mantz and George Blaurock in St. Gall and Appenzell, and Grebel with his great success in Grüningen. ${ }^{232}$ Sattler also launched a new program of outreach because, in his perspective on the situation regarding danger and possible persecution, he realized that the Anabaptists should not all be in one place. They should scatter into areas where they were

229 Augsburger, Pilgrim, p. 82.

230 Von Muralt, Quellen, no. 55, p. 63, in Blanke, Brothers in Christ, p. 54 .

${ }_{231}$ Augsburger, Pilgrim, p. 98.

232 Von Muralt, Quellen, p. 109. 
less well known and work in new territory. The movement spread and continued successful among the populace in areas such as Appenzell and Grüningen. Often five hundred were baptized at a time. ${ }^{233}$ Sattler himself worked with Grebel in the Gruningen area in september 1525. They enjoyed great success and popular support in the area because of the spread of the free church idea among the populace. "The government here was 'by the people' in contrast to the Zurich pattern. The spread of the free church concept was becoming a movement of the people."234 Sattler worked with Grebel in Hinvil and was present at the october 8, 1525, arrest. ${ }^{235}$ Bender says "that during the early months of Sattler's affiliation with the Swiss Brethren, he was zealously evangelizing in the area of Ufter, working with Munpret of Constance and Konrad Winkler of Wassberg. His evangelistic work was apparently in the area around Zurich, until in October we find him in Grüningen, working with Grebel and Blaurock." 236

\footnotetext{
23 Von Muralt, Quellen, p. 118.

234 Von Muralt, Quellen, p. 127.

235 Von Muralt, Quellen, p. 109.

${ }^{236}$ Christian von Hoff, "Konrad Grebel--Sein Leben und Wirken," (Ludwig Haften, 1925) p. 124, in Harold Bender, Mennonite Encyclopedia, vol. IV, quoted in Myron S. Augsurger, "Michael Sattler d. 1527, Theologian of the Swiss Brethren Movement" (Richmond, Virginia: Union Theolgical Seminary, unpublished dissertation, faculty of theology, 1965), no. 26, p. 7.
} 
Sattler's vision and commitment to the cause of the free church and the idea of freedom of conscience was his total life. When persecution came and even the first martyrdom for the cause of the free church in the person of Bolt Eberli, ${ }^{237}$ Sattler was convinced of the fact that the success of the free church depended on how the Brethren dealt with persecution and maintained a sense of unity. "In spite of persecution he was sure the free church movement was on its way to success. The New Testament church was becoming visible again."238 Along with preaching, he revealed his gift of writing. His determination and call to create a believers' church was his consuming passion as he wrote, traveled to congregations, and ministered to the movement that continued to spread. Another of Sattler's contributions to the movement was his strategy of training lay leaders to take over in the event of their pastors' arrest or martyrdom. 239 He also organized "forest meetings" to teach the Bible to local populations. ${ }^{240}$ These strategies were the strength and survival of the movement after the disbanding of the Zollikon Church.

\footnotetext{
237 Augsburger, Pilgrim, p. 119.

238 Augsburger, Pilgrim, p. 121.

239 Augsburger, Pilgrim, p. 127.

240 Augsburger, Pilgrim, p. 127.
} 
Everywhere the movement spread, the issue was that of the state church versus the free church and the authority of Scripture alone over that of the nonscriptural writings of the church fathers and secular thinkers that the Catholic and Protestant churches continued to respect, such as Augustine. ${ }^{241}$ For this reason, after the work in Zollikon was finished for Sattler, he and his wife settled for a brief period in the more tolerant and neutral city of strasbourg. Here Sattler had a period of invaluable discussion with the Strasbourg reformers, Wolfgang Capito and Martin Bucer. ${ }^{242}$ As a result of the "debates" with Capito and Bucer, Sattler clearly understood where the lines between the state church and the free church were drawn and the theological basis for each view. The issue of Christian love taking precedence over obedience became vital to Sattler as a result of these discussions. The Strasbourg reformers' position was that love and acceptance of all people into the church was the way to win them, in time, to faith in God. This was the heart of the difference in their view of the church, as it had been for Grebel in his opposition to Zwingli's view. "Bucer urged that love on the part of the Brethren should create in them a

24 Augsburger, Pilgrim, pp. 128-129.

242 Augsburger, PiIgrim, p. 149. 
willingness to unite with the state church despite their differences. But Bucer had not spoken about the need for love on the part of the state church leaders for the Brethren. He let the matter of their intense intolerance and persecution go unanswered." 243 sattler saw that their differences were in their views of what the church was, and their different views of love and obedience. Yes, love was to be Christian and open to all, but if it was used to compromise what they felt was the scriptural teaching of faithfulness to Christ and to discipleship at all costs, then that was unfaithfulness. To be united to the state would be a total denial of their convictions. In his letter to Capito and Bucer after he had left Strasborg, because of their disagreements regarding the meaning of love and obedience,

Sattler states that he was hindered from staying with the strasbourg reformers in their program because of Bucer's position that all other commandments are inconsequential in respect to the commandment to love. Sattler answered that his conscience was not to be coerced, and that the commandment to love was to be connected accordingly with the other commandments of God.244

Sattler wrote twenty articles as statements of the Anabaptist position on such matters as love, obedience, view of the church, theology, and religious liberty, to

\footnotetext{
243 Augsburger, Pilgrim, p. 155.

${ }^{244} \mathrm{Krebs}$, Elsase I, no. 70, in Augsburger, Sattler, p. 10.
} 
name a few, where they were not in total agreement with the reformers of strasbourg. The following are a few of these articles.

Believers are chosen out of the world, therefore the world hates them. Baptism incorporates all believers into the body of Christ, of which He is the head, Christ is the head of His body, i.e., of the believers or the congregation, but they are the true Christians who practice in deed the teaching of Christ. Such considerations, and still more of the same kind which do not come to mind, hinder me, dear brother, from understanding your general assertion on every subject which you advocate with the words of Paul cited above. Therefore, my beloved in God, I know of no comfort in all despair except to address an humble prayer to God for you and for me, that He might be willing to teach us in all truth by His spirit. I can no longer remain here without doing a special dishonor to God; therefore I must for the sake of my conscience leave the field to the opposition. I beg you herein, that you understand this as an act of Christian humility on my part. Be mercifully considerate, I pray, of those who are in prison and do not permit a merciful judgment to be superseded by a blind, spiteful, and cruel one. Those who are in error (if that they were) are not to be coerced but after a second admonition, to be avoided. Christians admonish benevolently, out of sympathy and compassion for the sinful, and do not legalistically coerce persons this way or that. ${ }^{245}$

The encounters with the strasbourg reformers and Sattler's conviction of the need of clarification, unity, and consolidation of the views of the Anabaptist movement were the general reasons for his move to South Germany and the town of Horb, where he had a successful ministry of preaching, teaching, and building churches.

245 Yoder, Legacy, pp. 22-23. 
"Consequently, Sattler accepted the invitation of Reublin to return to South Germany for a mission in the Hohenberg region in the late fall of 1526."246 Most importantly, the above reasons were also the motivation and basis of his greatest contribution to the Anabaptist movement and to the cause of the free church and freedom of conscience, the Schleitheim Confession or the Seven Articles.

Sattler saw the need for some kind of written statement of the Swiss Brethren's convictions concerning their church and the principles of Christian life in contrast not only to those of the protestant reformers, but also of other Anabaptist groups, especially those with spiritualist views such as Hans Denk. Denk believed that man is not totally depraved, for within him there is the light of the spirit of God, an inner light held to be equal in authority with Scripture. ${ }^{247}$ Sattler's position on these points was closer to that of Capito and Bucer, 248 especially regarding the exclusive authority of Scripture. Denk had secured a sizable following in Strasbourg, and Sattler felt he was leading people away from true biblical faith. A small "debate" or rivalry

$246 \mathrm{Krebs}$, Elsase, I, QCT VII, no. 70, in Augsburger, Sattler, p. 10. 247 Augsburger, Sattler, p. 164.

${ }^{248}$ Augsburger, Sattler, p. 164. 
between Sattler and Denk occurred prior to Denk's expulsion from Strasbourg. ${ }^{249}$ Another reason Sattler felt a confession or statement of discipline was imperative for the movement was the fact that there recently had been more radical spirits who, under Denk's emphasis of the freedom of the spirit, went about crying in the streets, "Woe, woe," warning people to repent. These activities led to excesses, such as running naked in the streets to emphasize the need of repentance to the inhabitants. This had caused confusion to some in the ranks of the movement as a whole. ${ }^{250}$ Sattler was afraid of disunity among congregations under these influences. "Others gave room for license under guise of liberty. There was also a strain of mysticism which resulted in making men a law unto themselves; they would not build a disciplined church without a clear standard.251

Another reason for the writing of the articles was to clarify the Brethren's views of church discipline. The Brethren had often been misunderstood and Sattler accused of legalism. He wanted to clarify the purpose of the Swiss Brethren movement. ${ }^{252}$

\footnotetext{
249 Augsburger, Sattler, p. 165.

250 Blanke, Brothers in Christ, p. 61.

${ }^{251}$ Augsburger, Sattler, p. 211.

${ }^{252}$ Augsburger, Sattler, p. 216.
} 
The constant and increased threat of persecution and martyrdom was a major factor in writing the Confession. ${ }^{253}$ Sattler became convinced of this after the martyrdom of Felix Mantz on January 5, 1527, in Zurich by drowning. ${ }^{254}$ He felt that the pressures of persecution would do one of two things: cause fear and thereby weaken the movement or challenge the movement to develop a new strength. He endeavored to do precisely the latter.

The death of Felix Mantz was the act in which the state church threw down the gauntlet before the Swiss Brethren. But it was taken up in a different way than they expected. The Brethren were people of peace who rejected the sword, but also people of courage who believed that all men had a right to freedom of faith. They set out to evangelize Europe, and the movement spread with a new intensity. The death of Mantz had occurred less than two years after the break with Zwingli, but the supporters of Mantz were greater in number than those of Zwingli. The sword was in the hand of Zwingli, but this was a struggle not of might or of power but of spirit. ${ }^{255}$

It was encouraging to hear of 1,500 baptisms in st. Gall and Appenzell 256 and the expansion of the movement in South Germany and in Austria. But persecution was a reality, and Sattler felt that the congregations needed not only a sense of unity, but also something written down that they could read and refer to. "With this

253 Augsburger, Sattler, p. 179.

254 Augsburger, Sattler, p. 193.

${ }^{255}$ Augsburger, Pilgrim, p. 200.

${ }^{256}$ Augsburger, Pilgrim, p. 201. 
increased danger, sattler felt it was urgent to draft a confession of faith. Such a confession could be put into the hands of the people, copied and passed from one to the other. They must be united to be strong as a voluntary movement. It was clear they would need spiritual strength to face persecution and stand the tests of the hour."257 Being at variance with the Protestant reformers was another reason for the need of a confession.

Sattler's passion for the free church and his conviction that it had a destiny in history was of primary importance. "The church which he was building had to be a free church, Christians must deny all interference from the state in matters of religion, and maintain complete freedom for the church and for individual consciences. The only scriptural position was that of complete separation of church and state. That separation would make discipleship costly."258 Sattler saw the Anabaptists as part of something momentous, something that would make a difference in history. ${ }^{259} \mathrm{He}$ sought to give the state church an answer. The

\footnotetext{
${ }^{257}$ Augsburger, Pilgrim, p. 160.

${ }^{258}$ Augsburger, Pilgrim, p. 181.

${ }^{259}$ Augsburger, Pilgrim, p. 207.
} 
Anabaptists were a church in their own right and sattler was dedicated to proclaiming that fact.

Sattler may well have been quite conscious that little time now remained to consolidate the movement he had planted. Just as October-December 1523 marked the first self-awareness of the Zurich radicals and December 1524-January 1525 the first formal breach, so early 1527 must be recognized as the coming of age of a distinct, visible fellowship taking long-range responsibility for its order and its faith. 260

After a discussion of the matter with Reublin and Blaurock, it was decided to call a meeting in the town of Schleitheim on February 24, 1527 the first of its kind in a thousand years. 261

The Schleitheim Confession and in particular the Seven Articles, will be discussed in view of the sources available. The purpose of the schleitheim synod is reflected in Sattler's accompanying letters and in the articles themselves. They reflect the fact that on the essential points of faith--justification, Christology, and soteriology--the Brethren were in agreement with Luther and zwingli. This explains the lack of doctrinal statements of faith. It shows that Capito and Bucer understood the Brethren's view as being in contrast to that of Denk. "The tone of Sattler's letter is consistent with the commendations by the strasbourg

260 Yoder, Legacy, p. 29.

${ }^{261}$ Augsburger, Pilgrim, p. 205. 
reformers, Capito and Bucer. They distinguished between the theology of Sattler and that of Denk, acknowledging Sattler as a Christian on the grounds of his belief in justification by faith." 262 Horsch says that the articles are primarily "a summary of the differences between the Swiss Brethren and the state churchmen of the time."263 Yoder states, "The clear statement of what distinguishes the Swiss Brethren movement from the Protestant and Catholic churches was at the same time the solidest defense against confusion and cross purposes within the ranks of the brotherhood as it began to take form as an autonomous movement."264

Samuel Jackson remarks about the Schleitheim Confession as a whole, "It is written in a very simple language, showing a very honest and Godfearing mind, and is in itself a triumphant refutation of the charge of fanaticism and immorality which Zwingli brings against the Anabaptists."265 Before looking at the opening letter, Augsburger states,

The articles refer not only to differences with Reformers and other Anabaptists, but also where they are in agreement such as the primacy points of

262 Beatrice Jenny, Das Schleitheimer Taufbekenntnis (Thayngen: Karl Augustin Verlag, 1951), p. 27.

$263 \mathrm{John}$ Horsch, Mennonite Quarterly Review (October, 1930), 245, in Augsburger, Sattler, p. 205.

264 Yoder, Legacy, p. 32.

$265 \mathrm{Jacks}$ on, Selected Works, p. 125. 
faith. In faith in Jesus Christ as sole and sufficient Redeemer they were of one mind with the Reformers. For this reason it is inadmissible to designate the Anabaptist churches as "sects." This is seen in the opening paragraph of the cover letter reflecting Trinitarian theology, a high Christology, and an awareness of the unifying power of divine grace. 266

And so the synod was opened with the following words:

May joy, peace, and mercy from our Father through the atonement of the blood of Christ Jesus, together with the gifts of the spirit, be with all who love God, who are scattered everywhere as before ordered of God our Father, where they are with one mind assembled together in one God and Father of us all: Grace and peace of heart be with you all. Amen ${ }^{267}$

Williams notes that the ultimate purpose of the synod was to unify the Brethren.

The Schleitheim Confession was, like most synodal utterances, shaped by the concerns of the movement to disavow excesses from within, and to resist challenges from without, but it was destined, because of the sheerness of its separation from the state, and the world, and because of the centrality the bonded community under evangelical disciplines, to become the norm for non-violent Anabaptists. ${ }^{268}$

As to the view of separation, not only in terms of the church, but spiritually with regard to the world, Sattler states, "We are of one mind to abide in the Lord as God's obedient children, sons and daughters, as those that have been and shall be separated from the world in everything. To God alone be praise and glory and all

\footnotetext{
260 Augsburger, Sattler, p. 51. 267 Jenny, Das Schleitheimer, p. 9. ${ }^{208}$ Williams, Radical, p. 294.
} 
will be in harmony. For the Lord is the Lord of peace and not of quarreling." 269

The first article deals with baptism, which was, of course, a main point of departure from the Protestant reformers, who believed in conducting infant baptism; a continuance of Catholic ritual which the Anabaptists condemned as unscriptural. The article reflects their view of faith and the church as a separation of true believers from the world. Baptism was a personal choice, a voluntary expression of inner faith, and therefore a reflection of freedom of conscience.270

First, concerning baptism: Baptism shall be given to all who have learned repentance and newness of life and to all who walk in the resurrection of Christ, and wish to be buried with Him in death, so that they may be resurrected with Him. This excludes all infant baptism, the highest and chief abomination of the pope. In this you have the foundation and testimony of the apostles themselves. ${ }^{271}$

The prominence of the doctrine of the resurrection is significant in this article focusing on the "new man" and giving emphasis to the new life in Christ. ${ }^{272}$

The second article discussed the "ban" or excommunication. The ban reflects the Anabaptist desire to keep the church pure, as in their view, a church that

269 Jenny, Das Schleitheimer, p. 10.

270 Jenny, Das Schleitheimer, pp. 44-45.

271 Jenny, Das Schleitheimer, pp. 10-11.

272 Augsburger, Sattler, p. 56. 
allows impurity in its midst ceases to be a separated and true church. It would become no different than the state church which allowed both Christians and non-Christians to become members. This is related to the whole issue of separation of church and state, as well as the spiritual idea of separation from the world. ${ }^{273}$ Though there were some who thought the use of the ban was too stringent and went against the freedom of the spirit, ${ }^{274}$ most felt that discipline was necessary for a true church and must reflect tolerance as well. ${ }^{275}$ It is also a reflection of the fact that the Anabaptists were not perfectionists nor did they advocate perfectionism. "The use of the ban as a function of the church, the ecclesia, is the brotherhood of believers giving and receiving rebuke."276 It also reflects their views of tolerance. The use of the ban was to keep the purity of the church from false doctrines or immoral behavior. 277 It was not a coerced type of discipline or a "new monasticism" as Capito had criticized. ${ }^{278}$ "The Anabaptists insisted that the voluntary nature of faith made the church visible."279 It reflected their tolerance in that the ban was only to

\footnotetext{
273 Augsburger, Sattler, p. 56.

274 Augsburger, Sattler, p. 216.

275 Augsburger, Sattler, p. 216.

276 Augsburger, Sattler, p. 216.

277 Jenny, Das schleitheimer, p. 51.

278 Krebs, Elsase I, p. 82, in Augsburger, Sattler, p. 217.

279 Jenny, Das Schleitheimer, p. 51.
} 
warn and admonish in love, not put to death or exile. 280 The ban was also directly related to the third article dealing with the Lord's Supper. It demanded purification before coming to the table.281

We agree as follows on the ban: the ban shall be employed with all those who have given themselves to the Lord to walk in His commandments, and yet who slip sometimes and fall into error and sin; the same shall be admonished twice in secret and the third time openly disciplined or banned according to the command of christ in Matthew 18. In the perfection of Christ, only the ban is used for a warning and for excommunication of the one who has sinned, without putting the flesh to death; simply the warning and the command to sin no more. ${ }^{282}$

Apparently there was divergent opinion on the meaning of separation from evil. There was, or course, already separation as a body of believers -- that was their position as a church. But separation from evil meant moral and spiritual distancing. It implied a call to holy living, in the world but not of the world. It did not mean being anti-social. It had a more spiritual than a social or physical meaning. ${ }^{283}$ It meant applying I Corinthians 6:14-20: "What fellowship hath light with darkness, or Christ with Belial?"

The fourth article begins

\footnotetext{
280 Augsburger, Sattler, p. 155.

${ }^{281}$ Because there was general agreement about the supper as a symbol or remembrance of the Lord's atonement, it will not be dealt with here.

282 Jenny, Das Schleitheimer, p. 11. 283 Jenny, Das Schleitheimer, p. 12.
} 
We are agreed on separation: a separation shall be made from evil and from wickedness which the devil planted in the world; simply that we shall not have fellowship with them. Since all who do not walk in the obedience of faith are a great abomination before God, to us the command of the Lord is clear when He calls upon to be separate from evil. ${ }^{284}$

He further admonishes us to withdraw from Babylon and the earthy Egypt. From this we learn that everything which is not united with our God and Christ can not be other than an abomination which we should shun and flee from. By this is meant all popish and anti-popish works and church services, meetings, and church attendance, drinking houses, civic affairs, commitments made in unbelief, which are highly regarded by the world and yet are carried on in flat contradiction to the command of God. From these things we shall be separated.285

Wenger says of the above,

This severe judgement on the state churches must be understood in the light of sixteenth century conditions. The state clergymen were in many cases careless and carnal men. All citizens in a given province were considered members of the state church because they had been made "Christians" by infant baptism. Also, in 1527 Zurich had begun to use capital punishment on the Swiss Brethren, with the full approval of the state church leaders."286

The role of the pastor in the congregation was the concern of article five.

We are agreed as follows on pastors in the church. The pastor shall have a good report of those who are outside the faith. This office shall be to read, to admonish, teach, warn, and to discipline, to lead out in prayer. He shall be supported of the church

\footnotetext{
284 Jenny, Das Schleitheimer, p. 12.

285 Jenny, Das Schleitheimer, p. 13.

$286 \mathrm{~J}$. C. Wenger, "The Schleitheim Confession of Faith," Mennonite Quarterly Review (September, 1945), 1, in Augsburger, sattler, p. 50 .
} 
which has chosen him. Should it happen that through the cross this pastor should be banished or led to the Lord through martyrdom, another shall be ordained in his place in the same hour. ${ }^{287}$

Williams points out the importance of this article. "It shows that, within less than three years after Grebel had re-baptized Blaurock in Zurich, the office of the pastor was clearly defined."288 $\mathrm{He}$ also observes that a prominent place is given to the reading of the Scripture. ${ }^{289}$ He "led out" in prayer, implying participation of others. "Anabaptist fellowships frequently gave opportunity for the listeners who felt inspired by the text to give his (or her) insight."290 For Anabaptists every believer was a potential minister of God's Word. 291 This article reflects their passion for evangelism; and in involving believers in participation, they were practicing and promoting the "priesthood of all believers" in church and in participation in the ministry.

Article six pertains to the use of the sword. It reflects their strict distinction between church and state as absolutely separate entities. It is also the

\footnotetext{
287 Jenny, Das Schleitheimer, pp. 13-14.

$288 \mathrm{Williams,} \mathrm{Radical}$, p. 184.

${ }^{289}$ Williams, Radical, p. 184.

${ }^{290}$ Wenger, "The Schleitheim Confession of Faith," Mennonite Quarterly Review, XIX (1945), 62 .

${ }^{291}$ Augsburger, Sattler, p. 63.
} 
article that received the most discussion. ${ }^{292}$ Some of the Anabaptists were in agreement with Balthasar Hubmaier, who advocated the use of the sword and who did not agree with the Brethren's pacifism. ${ }^{293}$ However, Sattler emphasized the importance of interpreting scripture "through Christ" pertaining to non-resistance. The Brethren represented what Stayer calls the Stäbler or complete non-resistance to war. ${ }^{294}$ The authority of the state is given by God; therefore, the state is under God.295 For them, it was not only separation, but the idea that because the realms of the state and the magistrate are non-spiritual, a Christian should not be involved in anything "outside of Christ." "They held the work of Christ to be the establishment of the Church in contradistinction to the state. The Anabaptists held the magistracy and the sword to be a divinely ordered function 'outside the perfection of Christ,' a function to restrain the evil and protect the good."296 Jenny asks two basic questions about separation: (1) Does the church have control over the body and life of the individual? and (2) is it right for the Christian to take

\footnotetext{
${ }^{292}$ Augsburger, Pilgrim, p. 216.

293 Augsburger, Pilgrim, p. 216.

294 James M. Stayer, Anabaptists and the Sword (Lawrence, Kansas:

Coronado Press, 1972).

295 Augsburger, Pilgrim, p. 216.

296 Augsburger, Pilgrim, p. 64.
} 
an active part in the affairs of the state? ${ }^{297}$ The first question concerns the Anabaptists' rejection of capital punishment, which was being used against "heresy." They believed that excommunication or the ban was the only action for the church rather than capital punishment with the support of state church leaders.298 The second question as to whether a Christian should serve in the magistracy, was more general. There were those, such as Hubmaier, who believed a christian could serve as a magistrate, but the Brethren differed with him on that point. 299

We agreed as follows concerning the sword: The sword is ordained of God outside the perfection of Christ. It punishes and kills the wicked, and guards and protects the good. In the law the sword was established over the wicked for punishment and for death and the secular rulers are established to wield the same. In the perfection of Christ, only the ban is used for a warning and for the excommunication of the one who has sinned, putting the flesh to death, simply the warning and the command to sin no more. Now it will be asked whether a Christian may or should use the sword against the wicked for the defense and protection of the good. Our reply is: Christ teaches and commands us to learn of $\mathrm{Him}$, for $\mathrm{He}$ is meek and lowly in heart and so shall we find rest to our souls. 300

\footnotetext{
${ }^{297}$ Augsburger, Sattler, p. 66.

298 Jenny, Das schleitheimer, p. 66.

299 Jenny, Das Schleitheimer, p. 66.

300 Jenny, Das Schleitheimer, p. 14.
} 
The seventh article dealing with the oath was directly related to the sixth. It was rejected for many of the same reasons, especially due to war and promises. One reason for the rejection of the oath was that christ, being the fulfillment of the Law, had forbidden the use of the oath. Also man does not have the power to fulfill his oath nor the scriptural right to bind God to support what man would swear to, but believers testify to the truth. ${ }^{301}$ Regarding the oath, one is a promise for the future, that may or may not be fulfilled. The other is a commitment to a real, concrete fact. "In swearing, one promises future things, while testimony is an assertion about the present."302 What is reflected here is the elevation of the New Testament as the highest level of revelation, and the Anabaptists strongly emphasized freedom or separation of church and state. ${ }^{303}$ Following the meeting, Sattler, as evangelistic strategist that he was, encouraged the local congregations to outline plans for evangelistic work as their greatest responsibility in fulfilling the Great Commission or world wide evangelism commanded by Christ himself. "The work of the 'Confession' was done; they had answered persecution by

\footnotetext{
301 Jenny, Das Schleitheimer, p. 250. 302 Jenny, Das Schleitheimer, p. 252. ${ }^{303}$ Augsburger, Sattler, p. 67.
} 
clarifying their position and achieving greater unity.

The free church had asserted its freedom in a responsible manner." 304

The Schleitheim Confession and the articles were written out of a deep sense of purpose and a commitment to freedom. But in the context of their time, they were written out of concern, insight, and wisdom for the consolidation and unity of the Anabaptist movement, its protection, and as a statement for the cause of religious liberty.

The cause of freedom lives on. The Sattlers were some of the first of thousands of Anabaptists who died as martyrs for Christ in the years following the synod. By the twentieth century many of the convictions for which the sattlers died have been recognized as vital facets of evangelical Christian faith. From these Anabaptist roots come various denominations in the world of our day. The Anabaptist-Mennonite brotherhood with over 600,000 members throughout the world carries on the heritage of the theology of Michael Sattler and his colleagues. The larger worldwide Baptist brotherhood is also indebted to this background for its origin and some of its theology. ${ }^{305}$

VII.

Probably the greatest and most influential Anabaptist leader was Balthasar Hubmaier. He is regarded

304 Augsburger, Pilgrim, p. 224.

30 Augsburger, Pilgrim, p. 288. 
as one of the most esteemed theologians by nearly all groups of Anabaptists. His life, ministry, and prolific writings were considered the authority by Anabaptists such as the Hutterites and Mennonites at the end of the sixteenth and beginning of the seventeenth centuries, despite the fact that his views regarding the sword and the Christian magistrate were not shared by the majority of "mainline" Anabaptists. For this reason, he was controversial in his lifetime. His outstanding preaching ability made him one of the most popular and famous Anabaptists in the Reformation. Regarding religious liberty, Hubmaier's contribution must be considered among the most influential, from both the point of view of evangelical reform and that of the modern Baptists:

$\mathrm{He}$ is generally regarded as the most important Anabaptist leader. There is a readiness to recognize in him a spiritual brother who represented in all essentials the major principles of the English Baptist movement which emerged in the early seventeenth century. English and American Baptist historians have generally treated 16 th century Anabaptism in a positive fashion. A. H. Newman, H. C. Vedder, Ernest Payne, and W. R. Estep are cases in point. ${ }^{306}$

Newman and Vedder, especially, emphasize Hubmaier's contribution for freedom of religion. ${ }^{307}$ Most Baptists

${ }^{306}$ Torsten Bergsten, Balthasar Hubmaier - Anabaptist Theologian and Martyr, ed., W. R. Estep, Jr. (Valley Forge, Pennsylvania: Judson Press, 1978), p. 39.

$30 \%$ Bergsten, Hubmaier, p. 40. 
and others today see in the Anabaptist movement the beginning of the modern Free Church movement. ${ }^{308}$ Hubmaier's ministry as a leader of two free churches, one in waldshut and another in Nikolsburg, testifies to this. This presentation of Hubmaier will deal only generally with his ministry and activities, primarily at waldshut, and specifically with his most important writings reflecting his contribution to religious liberty: The Eighteen Articles, on the Sword, and on Heretics and Those who Burn Them. A year after Hubmaier began his Anabaptist work in the town of Nikolsburg in Moravia, the Hapsburgs finally had him arrested for "insurrection" and "heresy." He was burned at the stake on March 10, 1528 in Vienna.

Balthasar Hubmaier was born sometime in the first half of the 1480s in Frieberg in Bavaria near Augsburg. He became a theology student of Johann Eck, the great Catholic theologian and Luther's rival, in 1503 at the University of Freiburg in Breisgau. He had already become a student of theology, and his extraordinary gifts of learning resulted in a Bachelor of Arts degree after only a year. He spent a short period in schaffhausen as a school teacher to finance his theological studies.

308 Bergsten, Hubmaier, p. 40. 
When Eck left for Ingolstadt, Hubmaier succeeded him as rector.joy Hubmaier's gift of eloquence as a preacher became well-known in the area after he became a priest. 310 He became prorector at the University of Ingolstadt with his teacher Eck, and he received his doctorate and lectured in theology. He became cathedral preacher at Regensburg in January 1516.311 His years at Regensburg were tumultuous because of his involvement in the social, political, and religious controversies involving his opposition to interest and usury, which set him against these common practices and against the Jews. He was set against the Hapsburgs as well. He advocated the civic freedoms of Regensburg over against the Hapsburgs, who were protectors of the Jews, and who were limiting the town's freedom. ${ }^{312}$ Throughout his life, Hubmaier would not only preach, but become actively involved in political and social affairs, becoming often a figure of controversy in his stand for freedom. His policies against the Jews were political and economic, not racial. But it must be remembered, that this was before he became

\footnotetext{
${ }^{309}$ Bergsten, Hubmaier, p. 49. 31 Bergsten, $\overline{\text { Hubmaier }}$, p. 50. 311 Bergsten, Hubmaier, p. 50. 312 Bergsten, Hubmaier, p. 59.
} 
an Anabaptist, and these attitudes toward Jews were common in the Middle Ages and later. ${ }^{313}$

When Hubmaier became the vicar of the largest parish in the town of Waldshut in 1521, he was already becoming aware of Luther's teachings. Waldshut's population of about one thousand had been given special rights, which Charles $\mathrm{V}$ reconfirmed in 1520.314 Waldshut belonged to the Hapsburg frontier in Austria. It was part of the Hapsburg hereditary lands with its own representatives, and it was indirectly subject to the government in Innsbruck.315 In Waldshut Hubmaier was a popular and eloquent preacher. During 1521 he was influenced by the humanist Wolfgang Rychard to read the classics and the Judicium of Oecolampadius on Luther's teaching. ${ }^{316}$ It was an apology for Luther's theology. However, he focused mainly on the Scriptures and especially on the Pauline theosophy. From this came his conversion to evangelical Christianity. He aligned himself with evangelical movements in both Regensburg and Waldshut by preaching and teaching the Bible to the people during 1522-1523, before settling permanently in Waldshut. He publicly attacked the Catholic Church. He described Catholic

\footnotetext{
313 Bergsten, Hubmaier, p. 59.

314 Bergsten, Hubmaier, p. 68.

315 Bergsten, Hubmaier, p. 68.

316 Bergsten, Hubmaier, p. 72.
} 
priests as murderers of men's souls and priests of Satan who preached falsehoods, and who withheld the Gospel from the people. ${ }^{317}$ Hubmaier initiated the Protestant Reformation in waldshut, becoming its greatly loved and supported pastor.

During the years 1523-1525, Hubmaier's Reformation in Waldshut was in contact and linked with that of the Reformation in Zurich. ${ }^{318}$ The Reformation in Zurich and that of Hubmaier in Waldshut resembled one another in several ways. They both had the support of the majority of the people. They both had the support of the city council or magistracy. Hubmaier's doctrines were close to Zwingli's and continued to be after he became an Anabaptist, except for his view of baptism and church discipline. ${ }^{319}$ Both held disputations in the course of reform, though Hubmaier's differed in that outside theologians were not invited, the civil authorities did not act as judges, and it was not open to the public. 320 He made contacts with the Swiss Brethren, and preached in St. Gall, and Appenzell. He became a friend of Zwingli and participated in the Second Zurich Disputation on

\footnotetext{
317 Bergsten, Hubmaier, p. 77.

sio Bergsten, Hubmaier, p. 78

$\therefore$ 'Estep, Beginnings, p. 23.

3.-vstep, Beginnings, p. 23.
} 
October 26-28, 1523. "Hubmaier was obviously a wellknown and highly respected participant in the disputation. According to Ludwig Häetzer's record, Hubmaier spoke five times during the discussion."321 The Waldshut Reformation was a part of the Swiss movement even though it was in South Germany and in Hapsburg territory.

The Waldshut Reformation became a heroic example of the fight for and insistence of a town on its right of religious liberty and freedom of conscience, despite dire threats of a powerful government to destroy those freedoms. This great drama was played out in the midst of political and religious ferments involving Hubmaier as a Reformer in the struggle for political and religious rights.

Hubmaier came under opposition from the Hapsburgs for religious as well as political reasons--religious, because Waldshut became a Lutheran town, political because under the influence of the Gospel and the Reformation, the town demanded its political freedom. This political aspect of the religious struggle was one of the characteristics of the dramatic history of the Reformation in Waldshut. ${ }^{322}$ Hubmaier's Protestant reform

\footnotetext{
${ }^{321}$ Bergsten, Balthasar, p. 83.

${ }^{322}$ Bergsten, Balthasar, p. 91.
} 
implemented the "Eighteen Articles" during 1523-1524.

Among these articles, which Hubmaier published in March

1524, were:

1. Faith alone makes us holy before God.

2. This faith is the acknowledgment of the mercy of God which he has shown us in offering his only begotten Son.

3. Such faith can not remain passive but must break out to God in thanksgiving and to mankind in all kinds of works of brotherly love. ${ }^{323}$

These three articles are Hubmaier's statements of reformed faith and establish the evangelical position in theology. The following articles reflect the major applications of the Waldshut reform of worship and church:

5. The mass is not a sacrifice but a remembrance of the death of Christ, therefore it is not an offering for the dead nor for the living.

7. Images are good for nothing, one should not invest or trust in wood and stone but only in the living "images" of God.

8. As every Christian believes for himself and is baptized so each individual should see and judge by the Scriptures.

12. No one will serve as a priest except he who preaches the Word of God.

13. The members of the church are obliged to support with adequate food and clothing those who teach them the Word of God purely, clearly, and sincerely. Hence fall courtiers, pensioners, incorporators, and absentees. ${ }^{324}$

${ }^{323}$ Balthasar Hubmaier, Schriften, ed. Gunnar Westin und Torsten Bergsten (Gutersloh: Gerd Mohn, 1962), p. 71 trans. Estep in Beginnings, art. 1-3, p. 24 . ${ }^{324}$ Estep, Beginnings, p. 25 . 
Waldshut's "heresy" aroused opposition from the Austrian authorities against Hubmaier's reform. They accused Hubmaier of:

He had publicly aligned himself with Zwingli, he had violated the imperial mandate by which no one was to join the "Lutheran sect." He had "erroneously" expounded the Holy scriptures, he had announced himself as the representative of four Habsburg cities, which was not true. The Austrians demanded that Hubmaier be handed over to the Bishop of Constance. The Waldshut Council rejected the accusations together with the Austrian's demand. The Waldshut authorities declared themselves unreservedly in support of Hubmaier. 325

Throughout this dispute and the entire Reformation, Waldshut stood firm in its insistence on its local liberties, 326 but most of all it refused to give up its pastor. This reflects its determination to stand for its political and religious freedoms. Not only the townspeople but the entire city council as well were relentlessly united in this effort.

\footnotetext{
325Bergsten, Hubmaier, pp. 91-92

$32{ }^{\circ}$ They claimed their rights on the basis of the "Nuremberg Mandate," which had come out of the deliberations of the second Imperial Diet at Nuremberg November 1522, to February 1523. It had discussed many things pertaining to the "Lutheran schismatic" movement and different religious doctrines then being taught. The "mandate" was issued on March 6, 1523. The mandate says that bishops and archbishops should appoint biblical scholars who would be responsible for supervising the preaching. If they find errors, they are to lead the offending preachers away from them with kindness; so that they do not give the impression of wishing to suppress the truth of the Gospel. But those preachers who are unwilling to be corrected are to be punished accordingly by their bishops. Bergsten, Hubmaier, p. 92.
} 
During the winter of 1523-1524, Waldshut openly defied the Austrian authorities and the Bishop of Constance by refusing to hand over Hubmaier to them for punishment. The waldshut council rejected the charge of disobedience on the basis of the fact that in their view, they were only acting upon their legal and religious rights as a town, and also upon their right of religious choice based on Scripture. Hubmaier was the undisputed leader of reform in Waldshut. As far as the council was concerned, his only "crime" was that he had preached the Gospel and influenced many people. ${ }^{327}$ The more the Austrians tried to suppress Waldshut's evangelical reformation, the more it grew. The Reformation had become popular, and the central influence on the political and religious life of the town was Hubmaier's preaching. The political attack launched by the Austrian government against Hubmaier was an attempt to win Waldshut back to the Catholic faith. Because of all these factors, Waldshut became an example to other towns in its stand for religious freedom.

The Reformation in Waldshut began to command widespread attention. No longer was it an exclusively internal affair of a remote little town, but through the refusal of its citizens to surrender their pastor it assumed a profound political significance and excited attention on all sides.

${ }^{327}$ Bergsten, Hubmaier, p. 95. 
Nowhere in the German part of the Austrian empire was the evangelical doctrine preached with such success as in Waldshut. Consequently, the ecclesiastical and civil authorities did not hesitate to take counter measures. ${ }^{328}$

Vedder explains some of the political reasons why the people of Waldshut felt justified in their defiance. "The citizens desired such liberties and immunities as the neighboring Swiss towns possessed, such as were enjoyed by the free cities of the Empire, and they would be satisfied with nothing less." 329

It was not only religious factors that caused opposition from the Hapsburgs. In addition, the socialeconomic demands of the rebellious peasants, whose uprising in South Germany had begun in the Waldshut area, were another factor in Austrian opposition. The town itself was not revolutionary, and defended itself on that point along with its rights ${ }^{330}$; however, the influence of Hubmaier's preaching, his sympathy with their grievances such as tax burdens, and the Reformation's emphasis on the freedom of the individual encouraged the town to make demands. ${ }^{331}$ Because of all these factors, Waldshut

\footnotetext{
${ }^{328}$ Bergsten, Hubmaier, p. 104.

${ }^{329}$ Henry C. Vedder, Balthasar Hübmaier, the Leader of the Anabaptists (New York: The Knickerbocker Press, G. P. Putnam's and Sons, 1905), p. 94 .

330 Vedder, Hubmaier, p. 96.

${ }^{331}$ Bergsten, Hubmaier, p. 110.
} 
received help from zurich with troops in its area, which kept the Hapsburgs distant at that time.

In Zurich and other evangelical centers people were following Waldshut's fight for freedom with sympathy and excitement. Martin Bucer, the strassbourg Reformer, wrote to Zwingli on October 31, 1524, expressing hope that the example of Waldshut would influence many other people and towns. In his eyes the heroic defiance of the little town was a miracle. 332

It was only because of its connection with the Reformation that help came from Zurich, but it could only be temporary for fear of war with the Hapsburgs. These events had forced Hubmaier into exile in Schaffhausen. ${ }^{333}$ During this time he wrote Concerning Heretics and Those Who Burn Them. This treatise focuses on freedom, toleration, and uncoerced faith. ${ }^{334}$

Hubmaier returned to Waldshut in October 1524, and his reform continued by removing images and celebrating mass in the vernacular. The negotiations in Rheinfelden from October 31 to November 5, 1524, between Waldshut representatives and the Austrian delegates, resulted in Waldshut's demanding its right of religious choice. Margrave Ernst von Baialen was the leader of the negotiations. Also, members of the Swiss Confederation were present to help the poor people of Waldshut gain

\footnotetext{
332 Bergsten, Hubmaier, p. 119.

${ }^{333}$ Bergsten, Hubmaier, p. 137.

${ }^{334}$ Bergsten, Hubmaier, p. 141.
} 
peace and quiet. Of course, the Austrians were intent on persuading the town to give up its pastor. ${ }^{335}$

They asked that the Gospel be preached in their town freely and without hindrance and by their "present Doctor"; They demanded the freedom to choose their own pastor and emphasized that they would not let Hubmaier go from them "without a fight." Waldshut should not be punished because of this quarrel, the liberties of the city should be confirmed by the archduke. ${ }^{336}$

At the end of 1524 and beginning of 1525, Hubmaier was in contact with Conrad Grebel and the future Swiss Anabaptists, which led to Grebel and Reublin's ministering in Waldshut. ${ }^{337}$ The issue of infant baptism led Hubmaier to the scripture and to his conviction that only believer's baptism was true. ${ }^{338}$ This resulted in the rupture of the Zwingli-Hubmaier friendship and the beginning of Hubmaier's becoming an Anabaptist. He was baptized by Reublin on Easter 1525 in Waldshut. 339 Despite this he continued to hold "Zwinglian" views on the use of the sword, Christian magistrates, and the oath.

With the threat of peasants rising against lords, Waldshut entered into negotiations at Constance in January 1525, to defend its civic rights and to refute

\footnotetext{
${ }^{335}$ Bergsten, Hubmaier, p. 147.

${ }^{336}$ Bergsten, Hubmaier, p. 148.

337 Bergsten, Hubmaier, p. 153.

338 Bergsten, Hubmaier, p. 157.

${ }^{339}$ Bergsten, Hubmaier, p. 230.
} 
the accusations of the Austrians. The charges included allying themselves with rebellious peasants, for the citizens had accepted help from soldiers of the swiss Confederation, and they had refused to hand over their pastor. The town made concessions on the matter of help from zurich. They rejected, however, all charges of revolution and disobedience.

In defending their freedom to choose their pastor
and in refusing to surrender Hubmaier they were
standing up for a right granted them in the
Nuremburg Mandate. Freedom to choose their own
pastor represented an essential part of Waldshut's
struggle for the freedom of the Gospel. The
Waldshut Council denied that the doctrine being
preached in their town was "revolutionary." In this
apologetic Waldshut explicitly recognizes both its
civil and religious authorities. Fear and reverence
are due to them but only insofar as they do not
abuse the obedience of their subjects contrary to
the ordinances of God, and this they claimed to have
learned from their doctor. ${ }^{340}$

The apologetic mentioned by Torsten Bergsten, one of Hubmaier's biographers, appears intact in Henry C. Vedder's biography of Hubmaier. Waldshut's motives were mixed, that is true, but Hubmaier's greatest concern was the freedom to preach the Gospel. Hubmaier wrote his "Apology" to secure that freedom.

With us neither tax nor tithes have ever been spoken against with the least word, but it has been sought to force us from the word of God by violence and against all right. That has been our only

34 Uergsten, Hubmaier, p. 159. 
complaint. Here I defy all men on earth and all devils in hell, that there was no other occasion against Waldshut but alone, alone, alone, the word of God. Those from Waldshut publicly promised at the last diet that they would to the prince and all others do all things as they were done before, as their forefathers have done, and much more; they offered to pour out their body, life, honor, and blood for the sake of the honorable house of Austria. They have always been the first to pay to the prince their obedience and tribute, but have asked for God's sake that they be allowed the simple, pure word of God. ${ }^{341}$

Hubmaier also wrote the "Apology" because he was convinced that Austrian opposition was due to religious reasons more than political. 342

For reasons of freedom, Waldshut supported the principles of the peasants while at the same time refusing to become disobedient and revolutionary toward the government. Waldshut only wanted the freedom of the Gospel and to choose their pastor. ${ }^{343}$ As the sociopolitical situation worsened, Zurich withdrew its military support. ${ }^{344}$ waldshut found itself abandoned by former allies. Its pastor, being an Anabaptist, the former ties to the Zwinglian Reformation were now severed as Hubmaier and Waldshut initiated a successful Anabaptist Reformation despite the difficulties.

\footnotetext{
${ }^{341}$ Vedder, "A Short Apology of Dr. Balthasar Hubmaier of Freidberg," Hubmaier, op. 13, in Vedder, Hubmaier, pp. 97-98.

342 Vedder, Hubmaier, p. 98.

343 Bergsten, Hubmaier, p. 176.

${ }^{344}$ Bergsten, Hubmaier, p. 177.
} 
The political situation in which Waldshut found itself after Zurich had refused to continue its support was desperate. When all of these developments are taken into consideration, there can be no doubt that waldshut sided with the peasants by its own free choice. The evangelical town, which wished to maintain its religious and political independence in the face of the Habsburgs and the Catholic Church, was forced by the course of events to take an active part in the Peasants' War. This took the form of some of the men of the town arming themselves with swords for defensive purposes in the event of an attack from Austrian forces, Hubmaier himself assisted fellow citizens in this. He did not hesitate, also, to take his part, like any other citizen, in the defense of the town, and bespoke armour, an arquebus, and a broadsword, that he might keep his watch at the gate. ${ }^{345}$

With the end of the Peasants' War, the Waldshut church became an Anabaptist congregation. It followed Hubmaier loyally by initiating believer's baptism. Hubmaier became a formidable opponent of infant baptism. This caused a split between himself and Zwingli. In a letter to John Oecolampadius of January 16, 1525, he stated:

For we have publicly taught that children should not be baptized. Why do we baptize children? Baptism, they say (Zwingli and Leo), is a mere sign. This meaning has nothing to do with babes; in Baptism one pledges himself to God, in the supper to his neighbor. I believe, yea, I know, that it will not go well with Christendom until Baptism and the supper are brought back to their original purity. ${ }^{346}$

\footnotetext{
${ }^{345} \mathrm{Egli}$, Aktensammlung, No. 911, in Vedder, Hubmaier, p. 93. j4ozwingli, Huldrici Zuinglii Opera, Completa Edito Prima, Latinorum scriptorum, Didactica et Apologetica, ab anno 1521 ad 1526. Zurich: Schulthess, 1832), op. II, 338, in Vedder, Hubmaier, pp. 108-109.
} 
Hubmaier also wrote other works on baptism such as the tract, The Christian Baptism of Believers. ${ }^{347}$ He carried on a literary debate on the issue with Zwingli.348 The Anabaptist Reformation in Waldshut followed the pattern of the Swiss Anabaptist congregations such as those in Zollikon and Wytikon. "At the end of April 1525, two Anabaptists from Zurich, Heinrich Aberli and Vli Hottinger, came to Waldshut; Jacob Hottinger, the most important man in the Anabaptist congregation in Zollikon, gave an account of his visit to Hubmaier in a letter to the Zurich Council, that his 'dear brother' Conrad Grebel went with him to Waldshut." 349

Throughout the remainder of 1525, Hubmaier worked toward more unity between his reform and that of Zwingli's. 350 This came to naught as Waldshut became more religiously and politically isolated from its former allies. Hubmaier was also distanced from other groups of Anabaptists because of his views on the sword and his views of the church. Because the council of Waldshut had become Anabaptist as well as the ordinary citizens, Hubmaier was seen by other Anabaptists as compromising the separatist view of the church. "There was almost a

\footnotetext{
${ }^{347}$ Vedder, Hubmaier, p. 114.

348 Bergsten, Hubmaier, p. 275.

349 Bergsten, Hubmaier, p. 242.

$3^{350}$ Bergsten, Hubmaier, p. 253.
} 
wholesale defection from Hubmaier and the radical religious movement in Waldshut. As a theologian and Anabaptist reformer Hubmaier stood between the evangelical reformers and the majority of the Anabaptists." 351

The defection was on the part of Zurich and the rest of the Protestant reformers such as that of Sebastian Hofmeister, the chief pastor at Schaffhausen, and others. In other words because of Waldshut's Anabaptism, it was abandoned by the Reformers, and because of its involvement in a political struggle, most of the Anabaptists abandoned it. Hubmaier maintained his bond with the Swiss Brethren, however. ${ }^{352}$ But his efforts at unity with Zwingli failed, because of their differing views on baptism. Because of the political pressures and without support from the Swiss, Waldshut finally capitulated to the Austrians on December 5, 1525 without bloodshed. ${ }^{353}$ Hubmaier personally led the town to surrender at the council hall. ${ }^{354}$ He then left Waldshut; over one hundred people went with him. ${ }^{355}$ Thus, the suppression of Waldshut was accomplished and its struggle for freedom; and the idea of freedom of religion continued

\footnotetext{
351 Bergsten, Hubmaier, p. 258.

352 Bergsten, Hubmaier, p. 265.

353 Bergsten, $\overline{\text { Hubmaier, }}$, p. 269.

${ }^{354}$ Bergsten, Hubmaier, p. 269.

${ }^{355}$ Bergsten, Hubmaier, p. 269.
} 
to spread in other areas such as Moravia. ${ }^{356}$ Hubmaier began a successful ministry in Nikolsburg.

Most scholars admit that there is a paradox between Hubmaier and the Swiss Brethren and most other Anabaptist groups. However, the influence of his writings on the majority of Anabaptists, including the followers of Menno Simons and the future English Baptists by the end of the century, is well known. The paradox, however, still exists and no one really has a definite answer. For Hubmaier, the church involved believer's baptism totally. In this he upheld the sovereignty of the individual and free choice as opposed to Zwingli's communal idea of baptism and the church. ${ }^{357}$ The church was for baptized believers only, yet he did not create a separatist church as did the Swiss Brethren. But, Hubmaier's reformation was different from that of Grebel and the Brethren, who were forced to become separatists. It can only be speculated that Hubmaier would have become a separatist if he had not had the support of his town council. Despite this, Walter Klaassen states that his views of the church were in fact the same as those of the Swiss Brethren:

356 Bergsten, Hubmaier, p. 241.

${ }^{357}$ Bergsten, Hubmaier, p. 293. 
Although Hubmaier parted company with the rest of Anabaptism on the questions of the sword, his view of the church is practically identical with that of the Swiss Brethren. The same is generally true of his view of the scriptures, though he does not make the sharp distinction between old and New Testaments that is found in the minutes of the Bern debate of 1538.358

Torsten Bergsen analyzes the differences between Hubmaier and Zwingli's views of baptism and the church:

As a defender of infant baptism, Zwingli regarded the obligation involved in baptism as an act of the church and of the Christian community in a collective sense. For Hubmaier it was the believer, the individual, who made a vow in baptism. Here lies the essential point of difference between Hubmaier and Zwingli. This is also the basis of their different understanding of the church. For Hubmaier the inner baptism of the Spirit is the prerequisite for true baptism in water. It is a witness and an act of confession. 359

In regard to the church in relation to the state,

Hubmaier was closer to Zwingli.

He shared much common ground with Zwingli. In contrast to the Zurich radicals, he had no desire to single out from the crowds, a minority group; he was much more concerned to preserve the unity and continuity of the existing church. He regarded the local church as a "believing congregation", but also reckoned with the possibility that the civil authority could be believing and Christian. $\mathrm{He}$ emphasized the duty of Christians to assist the authority in the execution of its powers. In this he was a genuine evangelical reformer. On the other hand, he was a typical Anabaptist, teaching that conscious faith confessed was a prerequisite for baptism and membership in the church of believers

\footnotetext{
${ }^{358}$ Walter Klassen, "Speaking in Simplicity: Balthasar Hubmaier," Mennonite Quarterly Review (1966), 139.

${ }^{359}$ Bergsten, Hubmaier, p. 293.
} 
only; and in his demand for a church discipline. He possessed both the Reformation emphasis on the collective and the Anabaptist insistence on that which is individual. Thus, he stood between the evangelical reformers and the majority of Anabaptists. 360

As example himself of these differences and similarities, Hubmaier worked closely with civil authorities in Waldshut. Some have said that he had a "state church" as well as a "free church"; but these descriptions are both inadequate. ${ }^{361}$ Combined in him were the reformer and the Anabaptist. Waldshut and Nikolsburg were not separatist nor were they territorial churches. Hubmaier was unique among the Anabaptists. His writings, however, would contribute to the free church movement.

In relation to the church and state, Hubmaier accomplished at Waldshut what Grebel had wanted to accomplish in Zurich. Hubmaier believed in the separate entities of church and state, or that of the spiritual and temporal. "Out of this people there has now become a separate and outward church."362 He was speaking about the difference between the universal church (spiritual church) and the visible church; but nevertheless, he saw the church as a separate entity from the state. That did not mean that Christians should not be actively involved

\footnotetext{
${ }^{360}$ Bergsten, Hubmaier, p. 297.

361 Bergsten, Hubmaier, p. 364.

${ }^{362}$ Vedder, Hubmaier, p. 206.
} 
in matters of state concerns such as being a magistrate, a judge or lawyer, and even using the sword. The sword was to be used only in the punishment of evildoers, and to protect the innocent. It could also be used for defense against militant oppression as he did in Waldshut, but never for coercion or against God's commands. Hubmaier, believed in religious liberty and separation of church and state. But he did not demand that Christians withdraw into noninvolvement in order to maintain the integrity of the faith. To the contrary, he saw such involvement as a Christian responsibility. ${ }^{363}$ For this reason, Hubmaier's view of the magistrate and use of the sword was that of the evangelical reformers. In his on The Sword, he uses scripture to support his view that the sword can be used with responsibility. That means it is used for defense, and for the punishment of the lawless. It is never used for coercion. Only a few of the passages from on the sword will be dealt with here.

Christ says to Pilate, "My kingdom is not of this world; if it were of this world my servants would doubtless fight for me, that I should not be delivered to the Jews." John 18:36. From that Scripture many brothers say, "A Christian may not bear the sword, since the kingdom of Christ is not of this world." Answer: If these people would use their eyes aright, they would say a very different

${ }^{363}$ Estep, Beginnings, p. 107. 
thing, namely, that our kingdom should not be of this world. But we lament before God that it is of this world, we stick in it clear over our ears and shall not be freed from it till the end. Whence also Paul, yet calls himself a sinner. Therefore all pious and godly Christian must confess themselves unholy even until death, whatever we may do of ourselves. Mark here pious Christian, the word of Christ, He says, "Put your sword into its place." he does not forbid you to bear it. You are not in authority; it is not your appointed place, nor are you called or elected thereto. But no one shall take the sword except one who has been elected and appointed thereto. ${ }^{364}$

It is clear from this that Hubmaier was what some have called, a realistic Anabaptist in that he believed that the Christian lives in the world and must honorably live his faith in it without being of the world. In Hubmaier's view, this meant being involved in the same faith-into-life application of the Swiss Brethren; but it also involved using the sword in a biblical manner. In the third passage, he explains why it is logical for a Christian, more than for unbelievers, to hold positions of responsibility.

Every Christian learns that one should not cease to protect and guard all pious and innocent men. The magistrate is bound by his soul's salvation to protect and guard all innocent and peaceful men; the magistrate is also bound to rescue and release all oppressed and persecuted men, widows, orphans, strangers, without any respect of persons, according to the will and command of God. Therefore God has hung the sword at their side and given it to his disciplines. ${ }^{365}$

${ }^{364}$ Hubmaier, Schriften, pp. $436-437$.
${ }^{365}$ Hubmaier, Schriften, p. 438. 
Concerning the idea that Christians should not sit in judgement or preside over court matters, Hubmaier says,

Christ does not condemn the office of judge, and no one should undertake to be a judge who has not been appointed and chosen, therefore the election of burghomasters, mayors, judges, all of whom Christ permits to remain, if with God and a good conscience they rule well over temporal and corporeal affairs. ${ }^{366}$

Concerning Christian judges, he states,

A Christian may properly and with a good conscience sit in court and council, and judge and decide about temporal cases; although the wranglers and disputants sin, yet they sin more if they take their cases before the unbelieving judge. If a Christian may and should in the power of the divine word, be a judge with the mouth, he may also be a protector with the hand of him who wins the suit, and punish the unjust. ${ }^{367}$

Comparing the ban and the sword, he says that both are scriptural because they are ordained of God.

See now, dear brothers, that these two offices and commands, of the ban and the secular sword, are not opposed to each other, since they are both from God. For the Christian ban frequently has place and authority, as for example in many spiritual offences against which the sword may by no means be used; when according to the occasion of the sin there should be punishment. ${ }^{368}$

Hubmaier's most famous treatise, on Heretics and Those Who Burn Them, was written, as was previously noted, during his time of refuge in a Benedictine cloister in

\footnotetext{
${ }^{366}$ Hubmaier, Schriften, p. 439.

${ }^{367}$ Hubmaier, Schriften, p. 441.

${ }^{368}$ Hubmaier, Schriften, p. 444.
} 
Schaffhausen, a few miles up the Rhine from Waldshut, where he had fled in order to protect Waldshut from Austrian attack. ${ }^{369}$ It was published in Constance on September 24, 1524; he chose Constance because it was a center of Protestant and Catholic controversy. The treatise consists of thirty-six articles and ends with Hubmaier's famous motto, "Truth is Immortal" -- Die warheit ist untödtlich, which appeared on most of his writings. It has been called the greatest tract on religious liberty and freedom of conscience to come out of the early Reformation. 370

In the first article Hubmaier redefines the term heretic. "Heretics are those who deceitfully undermine the Holy Scriptures, the first of whom was the Devil, when he spoke to Eve. You shall not surely die. Gen. 3."371 Hubmaier in his redefinition of heresy reverses the old concept of a heretic. Hubmaier said this for the purpose of defining the rights of the city of Waldshut and his own position. ${ }^{372}$ He stated, "I may err, I am a man, but a heretic I cannot be because I ask for correction from Scripture." 373 Throughout the work

${ }^{369}$ Estep, Beginnings, p. 48.

${ }^{370}$ William Estep, "Von Ketzern und Ihren Verbrennern: A Sixteenth Century Tract on Religious Liberty," Mennonite Quarterly Review (October 1969), 273.

$371_{\text {Hubmaier, Schriften, p. } 96 .}$

$3 \% 2$ Estep, Verbrennen, p. 279.

3 Hubmaier, Schriften, p. 83. 
Hubmaier attacks the death penalty for heresy. Other reasons for his attack against the punishment of heretics are that it is a vain attempt to build the Church by bloodshed; and that one may succeed in coercion, but genuine faith cannot be coerced. Compulsion leads to hypocrisy, not valid faith. The state has no divine right to judge or to make judgement of the church in such matters. Force is absurd to Hubmaier because you can neither destroy truth nor advance it by burning heretics, for "truth is immortal."374 Hubmaier says in essence that the medieval church had erred by labeling the wrong people as heretics. ${ }^{375}$

In the fifth article, Hubmaier advocates complete liberty of conscience and noncoercion of those who do not believe, be they heretics or infidel. "If they will not learn with strong proofs or evangelical reasons, then leave them alone, and permit them to rage and be furious, that those who are now filthy will become more filthy still. Rev. 7."376 Hubmaier speaks out against the typical reply of the inquisitorial system when he says in article thirteen, "So it follows now that the inquisitors are the biggest heretics of all since against

\footnotetext{
374 Estep, Verbrennen, p. 282.

${ }^{375}$ Hubmaier, Schriften, p. 98.

376 Hubmaier, Schriften, p. 97.
} 
the teaching and example of Christ they have condemned heretics to the flames and before the time of harvest root up the wheat together with the tares."377

In this article Hubmaier was attacking the common procedure of the clerical authorities' handing over the heretics to the secular authority, claiming thereby to be innocent of bloodshed. Article fourteen reflects the true Christian attitude that ought to prevail and the true purpose of Christianity. "For Christ is not come to butcher, destroy, and burn, but that those who live might have life more abundantly. John 10."378

The following articles reflect religious freedom, tolerance, and separation of church and state. They reflect, in short, Hubmaier's most revolutionary idea. Estep explains,

He was saying the matter of one's faith, its complexion, or its total absence is no concern of the state. Hubmaier is not advocating anarchy but religious liberty. The entire discussion is focused on political theory out of a religious and not a political concern. Since the state had invaded the domain which belongs only to God, Hubmaier could not do otherwise. The precedent for such a division of authority, Hubmaier finds implicit in the teachings of Christ. ${ }^{379}$

${ }^{377}$ Hubmaier, Schriften, p. 98.

378 Hubmaier, Schriften, p. 98.

${ }^{379}$ Estep, Verbrennen, p. 281. 
In article sixteen Hubmaier is reflecting Christian love and patience in dealing with pagans and all nonbelievers. He shows that conversion does not come by force. We can not convince unbelievers to believe. Our task is to preach or witness. It is God who does the converting, according to the conscience of him who is converted. It is God who does the convincing: To do otherwise is to usurp judgement that belongs only to God. "But a Turk or heretic will not be convinced by our act either with sword or yet by fire but alone with patience and witness and so we, with those who are patient, await the judgement of God."380

Article twenty-one suggests the use of the Bible in dealing with those who are unbelievers. It is only for the secular authority to use the sword against the lawless, not those who do not believe. Nor are Christians to use it for coercion. The Scriptures provide the guidelines and the message for dealing with all men, heretics or otherwise. The separate spheres of church and state are reflected in this article. "Every Christian has a sword against the godless, that is the Word of God. Eph. 6, but not a sword against the criminal." 381

\footnotetext{
${ }^{380}$ Estep, Verbrennen, p. 98.

${ }^{381}$ Estep, Verbrennen, p. 98.
} 
Article twenty-four clearly reflects the place of the authority. Its jurisdiction is in the area of enforcing the civill laws of society. "The authorities judge the criminals but not the ungodly, who may not injure body or soul, but are much more in need so that God can wisely draw good out of evil."382 It is not being instigated by the church to punish people it considers to be heretics. The separate spheres of church and state are to be strictly observed, thereby protecting the innocent whether they are believers or not.

Article twenty-nine is a protest against the violation of freedom of conscience and the right to act upon that conscience in the preaching of the Gospel. It is also an indictment against the church's hypocrisy in killing people of God. "Since it is a great disgrace to kill a heretic; how much greater the offense to burn to ashes the faithful preacher of the word of God without a conviction or arraignment by the truth."383 One of the reasons that the ungodly or the indifferent are to be left alone is that they may come to faith: "They were a necessary element of society both as an object of evangelism and as adversaries in a spiritual and theological conflict. It is Hubmaier's position that

\footnotetext{
382 Estep, Verbrennen, p. 99.

${ }^{383}$ Estep, Verbrennen, p. 99.
} 
genuine Christian faith can not be shattered by antagonists but strengthened." 384

In article twenty-two Hubmaier strikes at the blatant hypocrisy of the whole procedure of the church using the state to kill heretics as the sin of murder and to that it had added complicity to which the state became an accomplice. "Therefore, it is well and good that the secular authority put to death the criminals who do harm to the defenseless. Romans 13. But the godless or atheist who wants nothing for himself other than to reject the gospel."385

In all of these articles Hubmaier is expressing his most revolutionary idea. He is saying that the matter of one's faith, its choice, or its total absence is no concern of the state. Hubmaier is advocating freedom of conscience and liberty of religion. He is clearly advocating separation of church and state where religion is concerned.

For the cause of religious liberty, Hubmaier was one of the most influential of the Anabaptists. His ideas would be reflected again later in the century among the various dissidents and separatist groups, but especially among the emerging Baptists of England of the early

\footnotetext{
${ }^{384}$ Estep, Verbrennen, p. 281.

${ }^{385}$ Hubmaier, Schriften, p. 99.
} 
seventeenth century. Owing to Hubmaier's unique position between the reformers and the Anabaptists:

"By maintaining a fundamentally positive view of the state, while at the same time sharply separating the spiritual and temporal realms, the Baptists positioned themselves between the radical pacifism of the Anabaptists and the Calvinist tradition of magisterial reformation. The juxtaposition of civil loyalty and religious conviction enabled the Baptists to work for positive change within the political system. Throughout the seventeenth century Baptists were the vanguard of those who sought greater civil as well as religious liberties." 386

In order for this influence to have become a reality in late sixteenth and early seventeenth centuries and beyond, one must look at the influence that Hubmaier and his ideas continued to have after his martyrdom and throughout the sixteenth century within the Anabaptist movement and outside it. Despite his dissenting views on the sword, Anabaptists continued to consider him a theological authority and hold him in high esteem.

Several extant witnesses indicate the magnitude of the effect of Hubmaier's life's work, even after his death. These facts are found in sources derived from the Anabaptists as well as polemical writings directed against them. It is clear that sixteenthcentury Anabaptists continued to study Hubmaier's writings, their opponents continued to refute his theological position. ${ }^{387}$

\footnotetext{
${ }^{386}$ Timothy George, "Between Pacifism and Coercion: The English Baptist Doctrine of Religious Toleration," Mennonite Quarterly Review (January 1984), 48

387 Bergsten, Hubmaier, p. 382.
} 
Through his writings, Hubmaier continued to be influential in the region of Moravia and Austria especially with the Hutterites, as their documents show:

The later Moravian Anabaptists possessed a wide knowledge of those views of Hubmaier concerning the sword and possessions, which differed so much from their own; nevertheless, he was remembered as one of the most important Anabaptist teachers. A Dialogue on Zwingli's Book on Baptism was available to Hutterite historians. ${ }^{388}$

Among the Catholic polemical writings against him, those of the Jesuit Christoph Fischer indicate that Hubmaier's influence was held in high esteem by the Moravian Anabaptists at the beginning of the seventeenth century. ${ }^{389}$ In 1600 in Feldsberg in Lower Austria, Fischer published four anti-Anabaptist writings, Concerning the Cursed Origin of the Anabaptists, A Reply to Klaus Breutel, The Hutterite Dovecote, Fifty-four Important Reasons Why the Anabaptists Are Not to Be Tolerated in the Land. ${ }^{390}$ In Germany most Anabaptists were pacifist concerning the sword. However,

Two Anabaptists, Gross and Tck, had carved out a mediating position on the matter [the sword] as early as Hubmaier's Waldshut period. In the middle of the century, Pilgrim Marpeck was an example of this moderate attitude toward civil authority characteristic of the Anabaptist movement in South Germany. For this reason, circumstances were more

\footnotetext{
${ }^{388}$ Bergsten, Hubmaier, p. 384.

389 Bergsten, Hubmaier, p. 388.

390 Bergsten, Hubmaier, p. 388.
} 
favorable in Germany than in Moravia for Hubmaier's doctrine concerning the magistrate. ${ }^{391}$

Toward the end of the sixteenth century, the ideas of Hubmaier were current among the Swiss Anabaptists. Examples are a tract of Sebastian Frank, and two by Menno Simons.

The collection was written by the same person who possessed the Anabaptist manuscript. The Art Book, Kunstbuch, between 1579 and 1594; on the title page of this collection of tracts is written "Dye warheitt istt unndöttlych." Here again, is evidence that Hubmaier's motto was still current among the Anabaptists. ${ }^{392}$

The influence of Hubmaier speaks for itself and still speaks today. Die Warheit ist untödlich.

The three leaders who founded and led the early Anabaptist movement in Switzerland, South Germany and Austria--Conrad Grebel, Michael Sattler, and Balthasar Hubmaier--were men of courage, vision, and conviction, and each possessed the passion for truth and freedom that helped lay the foundation of the idea of religious liberty and freedom of the individual that we cherish and hold sacred in western culture.

\section{VIII.}

From the early period of Anabaptism in the 1520 s to the later period in the 1570 s and into the seventeenth

\footnotetext{
${ }^{391}$ Bergsten, Hubmaier, p. 390.

${ }^{392}$ Bergsten, Hubmaier, p. 395.
} 
century, there were transitional leaders such as Pilgram Marpeck who did much to synthesize evangelical and particularly, the "church" type Anabaptist doctrines in the 1540s. Marpeck's great contribution to the movement was his Verantwortung of 1544 which consolidated and organized Anabaptist theology into a more systematic and clarified unity. "Marpeck took the initiative in attempting to formulate Anabaptist church order for the moderate evangelical separatists. His separatism constituted a major challenge for municipal clergy."393 For purposes of religious liberty, Marpeck wrote about the limits of political authority. He believed that the state could not invade the realm of the spirit. It could not demand anything that violates conscience. When it did, Christians were obliged to affirm the sovereignty of Christ alone. The limits of political authority were drawn at the point of faith. ${ }^{394}$ Marpeck was a contributor to the idea of religious liberty and the separation of church and state. Therefore, he was a precursor to the later Anabaptists and their interaction with the English Separatists late in the century.

In order to understand the survival of the possible contributions of the Anabaptists to the idea of religious 
liberty as it appeared in the late sixteenth and early seventeenth centuries and on into modern times, I will summarize the historical evidence gathered by several authors. I will not attempt to prove a direct link between the Anabaptists of the sixteenth century and the English Baptist movement; nor to prove a direct link between Anabaptism both in England and in the Netherlands, and the development of English Separatism. The presentation here will only reflect the views of scholars in the field who have claimed to show Anabaptist influence, directly or indirectly, on these groups.

By Separatist is meant those who separated or came out of the Church of England due to dissatisfaction with the established church. They advocated ecclesiastical separation and formed religious communities, churches, or congregations outside the established church. It is applied to Independents and those who agreed with them in rejecting all ecclesiastical authority outside the individual congregation.

As early as the 1530s, Anabaptism appeared in England. Henry VIII issued a proclamation against them in 1535,

For because that of late many strangers, born out of the King's obedience are arrived and come into this realm, which, albeit that they were baptized in their infancy and childhood according to the 
ordinance of the universal church of Christ; yet not withstanding, in contempt of the holy sacrament of baptism so given and received, they have of their own presumption and authority lately rebaptized themselves; and over and beside that, they deny the most blessed and holy sacrament of the altar to be really the very body of our Lord Jesus Christ; they keep, hold, and teach other divers and sundry pestilent heresies against God and his Holy Scriptures. ${ }^{395}$

The Anabaptists had been driven to England because of the persecution against them in Holland during the spanish rule of Duke Ferdinand of Alva. ${ }^{396}$ With Anabaptists in England in the 1530s, there continued to be succeeding generations of originally continental Anabaptists in England, settling in areas such as London, Essex, East Anglia, Norwich, and Kent. ${ }^{397}$ By the end of the 1540 s there was evidence of continued Anabaptist presence and influence. Henry Hart was one of the better known nonconformists of Edward's reign who showed influences from Anabaptism. In referring to the sectaries and to Hart himself, John Strype says, "They were the first that made separation from the reformed church of England, and held opinions of the Anabaptists and Pelagians."398

\footnotetext{
${ }^{395}$ Paul L. Hughes and James F. Larkin, Tudor Royal Proclamations, vol I: The Early Tudors (1485-1553 (New Haven \& London: Yale University Press, 1964), p. 227 ${ }^{396}$ Williams, Radical, p. 1177.

${ }^{397}$ William E. Page, Victoria History of the County of Essex, vol. II (London: Archibald Constable \& Co., 1907), p. 34, and William E. Page, Victoria History of the County of Kent, vol. II (London: St. Catherine Press, 1926), p. 77. $398 \mathrm{John}$ Strype, Ecclesiastical Memorials Relating to the Reformation and the Religion and the Reformation of it and the Emergencies of
} 
It can be established that Anabaptists were certainly present and active in churches in certain areas of England. Opinions vary on the extent of influence which the Anabaptists had on the rise of English Separatism. Latourette insists that Anabaptist contributions to English Separatism is undeniable. "They contributed to the emergence or development of movements in Britain, chiefly the Independents, Baptists, and Quakers. Through these, especially the first two, they were to have a profound and growing influence on the christianty of the eighteenth and notably of the nineteenth and twentieth centuries."399 It was due to the scholarship of Irvin B. Horst that more light was shed on Anabaptist influence on English Separatism.

The influence of Anabaptism on Independency and the later Congregational movement can be traced chiefly on the form of church government and the character of church worship and life. Much more radical was its influence on the movement which was to bear the name "Anabaptist" longest, the General Baptists, who were the closest English counterpart to the mainline Anabaptists on the Continent. (Täufer, Mennonites) .400

Anabaptist ideas continued to be prevalent amongst the early groups of English Separatists such as the Brownists

the Church of England, vol. III, pt. 2 (Oxford: Clarendon Press, 1820), pp. 369-370.

${ }^{399}$ Kenneth S. Latourette, A History of Christianity, vol. II: A.D. 1500 - A.D. 1975 (New York: Harper \& Row, 1975), pp. 779-780. ${ }^{400}$ Irvin B. Horst, The Radical Brethren - Anabaptism and the English Reformation to 1558 (Niewkoop: B. de Graaf, 1972), p. 179. 
and Barrowists, visible in such practices as the refusal to baptize children and the practice of discipline in the $1580 s .401$

When Francis Johnson, a Puritan clergyman, became a Separatist under the influence of the Barrowists, he became a pastor of a Separatist congregation in the 1590s. Persecution under Elizabeth I led to his imprisonment and the flight of his congregation to Holland in 1593, which settled at Campen.402 Johnson arrived in Holland sometime in 1597. Johnson's church was influential in propagating their teachings which had marked Anabaptist characteristics. ${ }^{403}$ This was the beginning of the "Netherlands" period for the English Separatists and their relationship with the continental Anabaptists, who by then were called Mennonites after the Anabaptist leader in Holland, Menno Simons, who became their leader in the early 1540s. ${ }^{404}$ Menno's name would be used to refer to Anabaptists especially in Holland, later in the century. They would be called Mennonites or Anabaptist-Mennonites even in Germany, Switzerland, and Moravia. ${ }^{405}$

\footnotetext{
${ }^{401}$ William R. Estep, The Anabaptist Story (Nashville: Broadman Press, 1963) p. 208. ${ }^{402}$ Estep, Story, p. 209.

403 Williams, Radical, p. 210.

${ }^{404} \mathrm{Williams}, \overline{\text { Radical }}$, p. 595.

4 bWilliams, $\underline{\text { Radical, }}, 590$.
} 
In order to understand the sequence of events between the English Separatists in Holland and the Anabaptists, it is important to look at the background of these events. By the 1570 s Holland was in the midst of its struggles for independence against spain and Philip II, whose rule had threatened their degree of freedom after 1566 in his efforts to subdue the Netherlands. The Netherlands revolted in 1566, resulting in a nationalist war against Spain, which in turn produced an alliance with England and the liberation of Holland by William of Orange. Out of this national struggle came the continued growth and spread of Calvinism in the Netherlands. Calvinism which was similar to Zwinglianism ${ }^{406}$, but with its emphasis on predestination and God's sovereignty, had spread into the Netherlands by the 1560s. But Dutch Calvinists were influenced by Anabaptists in their views of church organization.

The Calvinists, who had come upon the scene late, in the "third" phase of the Reformation in the Netherlands, possessed a militant spirit which distinguished them from the "withdrawn" pacifist Mennonites. Dynamic preachers trained in the teachings of the Genevan Academy proclaimed their acutely formulated dogmatics with an irresistible enthusiasm. With their faith in a divine mission to establish the true church with the word and the Sword, and with their excellent synodal organization, they were the men of the hour. They

400 see chapter on Zwingli. 
adopted the conventicular and covenanting impulse of the Anabaptists and gave it a new dogmatic, nationalist impetus. ${ }^{407}$

Out of all these developments, including intolerance on the part of the Calvinist Dutch Reformed Church in Holland toward Anabaptists, came advocates of tolerance and even of liberty of conscience. One was Dirk Coornhert, a liberal Catholic who disliked Calvinism and Catholicism, advocated a "middle-ground church," that would be based solely on scripture and that would act to mediate between the different churches and sectarian groups. ${ }^{408}$ He advocated tolerance for both Catholics and Mennonites, even though he tended toward a spiritualist approach. His ideas influenced a predominantly Anabaptist church in Emden in 1568, called the Waterlanders which had revolted against Menno Simon's stricture concerning the ban, and formed its own congregation. Coornhert's more liberal approach influenced John (Hans) de Ries, who became the leader of the Waterlanders. In 1577 de Ries and Simon Michiels drew up the Articles of Faith at Alkmaar, which became the first formal Anabaptist confession of faith in the Netherlands. ${ }^{409}$ It retained traditional Anabaptist theology and views of the church and baptism, but

${ }^{407}$ Williams, Radical, p. 1185.

${ }^{408}$ Williams, Radical, p. 1188.

${ }^{409}$ Williams, Radical, p. 1189. 
liberalized views of the ban.410 By 1581 the

Waterlander's main congregation was in Amsterdam.

The Amsterdam assembly did not endorse Spiritualism, but it made important concessions in two sectors. The traditional stricture against marriage with outsiders was relaxed, members were also allowed to accept public office. The Waterlander assembly of 1581 marks the opening of a new epoch. The liberal ferment among the Waterlander Anabaptists had its counterpart in the policy of William of Orange. ${ }^{411}$

This counterpart was the achievement of the Toleration of 1577, which gave the Anabaptists civil and religious freedom and marked the end of an epoch of persecution in the Netherlands.412 The waterlanders received other Christians into their fellowship who were not Mennonites, but who held the same scriptural views of Christ, justification, the church as a free gathering of believers, and believer's baptism.

In the early seventeenth century, John Smyth, a Puritan clergyman who had become a separatist from the Church of England in 1606 when he was elected a minister of a Congregational church in Gainsborough on Trent, went to Holland due to James I's persecution of dissenters. Smyth started a second separatist church in 1607, and in 1608 after contacts with the Waterlanders of Amsterdam, he became convinced that believer's baptism was the only 
true one and therefore re-baptized himself (se-baptism). Two other leaders in his congregation, Thomas Helwys and John Murton were also re-baptized.413 As a result of the Waterlander Anabaptist influence, Smyth and his followers applied for Waterlander membership in 1610. Smyth and Helwys both had shed much of their predestination and views of original sin concerning infants and adhered to the Waterlander views with respect to non-resistance. Though there were mixtures concerning the magistrate in the fellowship, Timothy George's view is that Smyth was closer to the traditional Anabaptist-Mennonite position than Helwys.

In seeking admittance to the Waterlander Church, Smyth and forty-two members of his congregation signed the Confession of Hans de Ries, the Mennonite pastor. Although the waterlanders represented a liberalizing tendency within the Dutch Mennonite tradition and at one point had conceded that a Christian might hold a local civil office, "on the condition that he refrain from counseling any bloodshed," the Confession of Hans de Ries enjoined explicit non-resistance and abstention from things "attached to worldly office," such as the waging of war and the destroying of life and property of the enemy. Smith not only signed this confession but also wrote in Latin an elaborate defense of many of its articles. Here Smyth agreed that it was necessary to exclude the magistrate from the Church of Christ, which bears only spiritual arms and fights only a spiritual war. He further claimed that both the office of the magistrate and the use

\footnotetext{
413 Calvin A. Pater, Karlstadt as the Father of the Baptist Movements: The Emergence of Lay Protestantism (Toronto: University of Toronto Press, 1984), p. 261.
} 
of the civil sword had been forbidden by Christ, the Apostles and the primitive church. ${ }^{414}$

When John Smyth repudiated his se-baptism on the basis of Scripture he also declared the other baptisms of his congregation invalid. The views of both Calvin Pater and William Estep seem to indicate that the reasons for his declaring the se-baptisms of his other members invalid was his desire to be more acceptable to the Waterlander church. Perhaps he felt they were invalid because he had performed them as a person who had rebaptized himself. This became the cause of the split between Smyth and the followers of Thomas Helwys and John Murton because they saw in this the danger of continuous baptisms and multiple churches, or succession. ${ }^{415}$

But now to come to maister Helwys his separation, against which I have done nothing in writing hitherto, notwithstanding I am now bound in conscience to publish an apologie of certaine imputations cast uppon me by him in his writings. As first the synne against the holy ghost, bicause I have denied some truth which once I acknowledged, and wher with I was inlightened. But that the succession I hold as I did hould then, it may by two or three gathered together in the name of Christ, be renewed and assumed againe: and hearin ther is no difference betwist maister Helwis and me. ${ }^{416}$

Thomas Helwys and his followers rejected Smyth's repudiation of their re-baptisms and considered the

${ }^{414}$ George, "Between Pacifism," p. 35.

415 Pater, Karlstadt, p. 266.

$416 \mathrm{~W}$. J. Whitley, The Works of John Smyth. 2 vols. (Cambridge: Cambridge University Press, 1915), p. 756. 
baptisms valid. They left Smyth and his congregation and applied for membership in the Waterlanders and were rejected. "The only obvious disagreement that originally divided Smyth and Helwys was Smyth's repudiation of the baptisms that he had administered, one of them being that of Helwys. Helwys charged Smyth with teaching succession, the bane of Separatists."417 When Smyth became a Waterlander Anabaptist, he moved more towards toleration and religious liberty, as well as separation of church and state, denying the role of the magistrate in religion. As a Baptist he also moved closer to a position of free will and away from predestination. He became an advocate of freedom of conscience because he began to see God as tolerant and benevolent rather than one who elects only. ${ }^{418}$ Smyth grew more tolerant and open in his views of liberty with respect to others, including believers, and expressed a desire for love and acceptance on an equal basis toward all people because of his views of freedom of choice in matters of religion.

My desire is to end controversies among Christians rather then to make and mainteyne them, especially, in matters of the outward Church and ceremonies: and it is the grief of my hart that I have so long cumbered myself, and spent my time therein: and I professe that difference in judgement for matter of circumstance, as are all

417 Pater, Karlstadt, p. 265.

418 Pater, Karlstadt, p. 265. 
things of the outward church, shall not cause me to refuse the brotherhood of anie penitent and faithful Christian whatsoever. And now from this day forward do I putt an end to all controversies and questions, about the outward church and ceremonies, with all men: and resolve to sped my time, in the mayne matters wherin consisteth salvation. ${ }^{419}$

It is Pater's view that Smyth and Helwys were closer in their Anabaptist views to one another than has been interpreted by others (George and Estep). "Historically there are many lines of continuity between smyth and his former disciples."420

Thomas Helwys was a Puritan, and a lawyer who was influenced by Smyth and baptized by him. He also was attracted to the Waterlanders and abandoned predestination. His doctrine of Christ was traditional and his view of the church was that of independent congregations who preach the Word and support their own ministers. ${ }^{421}$ Helwys was close to Smyth linking divine initiative and human response. He rejected a forensic doctrine of justification.422 "Helwy's understanding of predestination, except for the doctrine of the fall of humanity in Adam, is anti-Calvinistic ... in fact, typically Dutch Baptist."423 Helwys retained some

\footnotetext{
i19 Whitley, Smyth, p. 755.

4 ivater, Karlstadt, p. 265.

421 Pater, Karlstadt, p. 267.

422 Pater, Karlstadt, p. 267.

${ }^{423}$ Pater, Karlstadt, p. 267.
} 
Calvinism in his view of sin, but he rejected the Mennonite prohibition of oaths, bearing of arms, participation in government and excommunication, following others in the waterlander Church. "The Waterlanders accepted the magistracy, except for opposing it in principle when government wields the sword or tries to coerce the consciences of its subjects, for example by seizing the property of religious or other types of dissidents." 424 Helwys became Anabaptist and advocated liberty of conscience, but he also retained some of his Puritan and Calvinist heritage as cited above. For this reason, he and his congregation went back to England.

Helwys went back to England with a handful of followers. Like the Dutch Doopsgezinden (Anabaptists in Holland), they adopted the name of 'Baptist" for their faith. At Spitalfields, near London, they established the first Baptist congregation on English soil. Helwys had been influenced by Smyth and the Waterlanders on religious liberty. In 1612 Helwys published A Short Declaration of the Mistery of Iniquity 1612 in which his opposition to predestination undergirds his defence of religious freedom. Since God permits everyone to choose freely for or against him, the magistrates have no right to intervene in this free process, and even errors like Roman Catholicism must be tolerated. ${ }^{425}$

For these reasons Pater believes it is impossible to advocate one side or the other with regard to Baptist

424 Pater, Karlstadt, p. 269.

425 Pater, Karlstadt, p. 269. 
origins in connection with Smyth or Helwys. They both were close to the same views; Helwys became an advocate of religious freedom, sending his A Short Declaration, to James I. This resulted in Helwys' imprisonment and death in 1615. John Murton succeeded Helwys until his death in 1626. Helwys, in his A Short Declaration, developed his ideas concerning the relationship of the civil power to the church. He reminded the king that he did not have divine power over the consciences of men. "No power over ye immortall soules of his subjects, to make lawes and ordinances for them, and to set spiritual lords over them. For it should be evident that if the ruler enjoyed any authority to make spiritual laws, "he is an immortal God, a mortall man."420 Helwys established a new precedent when he stripped away the unity of the state with the church and by so doing seriously deprived both of their basis of persecution. "Helwys' outstanding contribution lay in the fact that he disassociates completely the magistrate from the religious life of the nation and by fearless logic swept away the theoretical justifications which for so many centuries had been advanced to support the persecutions of heresy."427 Helwys advocated complete

${ }^{426}$ Thomas Helwys, A Short Declaration of the Mistery of Iniquity (London: Grayer Inne, 1612; reproduced by London: Kingsgate Press, 1935), in Jordan, Toleration, vol. II, pp. 275-276.

427 Jordan, vol. II, p. 274 . 
toleration of heresy and error, teaching that they should not be punished by the state. He taught that the king had no authority to coerce people in religion and that the king should restrict the powers of bishops in matters of dealing with individual choice of religion and worship, and restrict their powers to those of spiritual matters only. "The state must disavow all authority in religion and in conscience, both in the indifferent matters of ceremony and in the greatest things between God and man."428 Helwys stressed the fact that Christ had commanded his followers to win the world by preaching the Gospel and never by coercion or punishment of those who chose not to believe. He anticipated Roger Williams in his call for tolerance, which was in fact liberty, because true religion was based upon tolerance, but even more so, on liberty. He called for the right of all Christians to have the freedom to read and hear the word of God in their own language and to pray in public worship in their own language. ${ }^{429}$ Helwys was not only demanding legal toleration, but religious liberty. Under Murton they had returned to Holland because of intolerance and persecution in England. They again applied to the Waterlander Church,

\footnotetext{
${ }^{428}$ Helwys, Short Declaration, 56-57, in Jordan, Toleration, vol. II,
p. 275 .

${ }^{429}$ Helwys, Short Declaration, in Jordan, Toleration, vol. II, p. 54.
} 
but were rejected because of their views on the oath and bearing of arms. ${ }^{430}$ But these views remained mixed among the various Baptist groups. 431 "The Baptists in England, later known as "General Baptists," became the first Baptists in North America when Roger Williams founded "Providence Plantation" (Rhode Island) in 1636. The Particular Baptists came on the scene in 1641."432 The General Baptists held more to a view of free will yet at times were more calvinistic in their views on predestination. The Particulars were more positive towards the magistracy than the Generals, but they rejected the Calvinistic theocratic position of the Separatists, following the waterlanders, and General Baptist views. ${ }^{433}$ "Thus, the Baptist movement advanced from continental Europe to England and there evolved further. It is the English Baptists, especially those that were transplanted to the United States, who have moulded modern notions of freedom of religion and the separation of church and state." 434

In Estep's view, Smyth was closer to the Mennonite position on the magistrate and oaths than Helwys. Though both were close to one another in their views regarding

\footnotetext{
${ }^{430}$ Pater, Karlstadt, p. 272.

${ }^{431}$ Pater, Karlstadt, p. 273.

432 Pater, Karlstadt, p. 273.

433 Pater, Karlstadt, p. 276.

${ }^{434}$ Pater, Karlstadt, p. 276.
} 
Calvinist theology and the mixture of related factors, as has been shown, Helwys reflected more the position of Hübmaier.

There is one important difference between Helwys' position regarding the magistrate and that of Smyth. While Smyth's view became identical with that of the Waterlander Mennonites, Helwys' view was closer to that of Balthasar Hübmaier. The typical Mennonite view held that a Christian could not be a magistrate. Helwys disagreed. Since the magistrate was ordained of God for an orderly society, he could not be justifiably barred from the church. Without question, Helwys was greatly dependent on smyth for his theology. Both Smyth and Helwys were dependent on the Mennonites for the determinative features of what was to become known as Baptist faith and practice. However, on the separation of church and state there is a significant difference between Helwys and the Mennonites. A positive orientation of the Christian toward the state became, under the creative mind of Helwys, characteristic of Baptists. Subsequently, the Baptists of England and America were to become vocal, consistent, and effective champions of religious freedom and church-state separation. ${ }^{435}$

Roger Williams, the greatest of all the apostles of freedom, was the historical link between the English

Baptists and the American Baptists, and the American

Baptists were the indirect link to the freedom writers in the American Constitution.

English Baptists were to find ardent and eloquent spokesmen for their cause. Among these Roger Williams emerged on the American scene. He became the most prominent of many able religious and political architects of the seventeenth century.

${ }^{435}$ Estep, Story, pp. 218-219. 
The inspiration for much of his thought and work apparently came from the General Baptists and through them from the Continental Anabaptists. ${ }^{436}$

A resemblance is visible between the writings of Williams and Hubmaier on the topic of religious liberty. Williams declared in The Bloudy Tenent of Persecution for Cause of Conscience,

All civil states, with their officers of justice, in their respective constitutions and administrations, are proved essentially civil, and therefore not judges, governors, or defenders of the spiritual, or Christian, state and worship. . . . It is the will and command of God that, since the coming of his son the Lord Jesus, a permission of the most Paganish, Jewish, Turkish, or anti-Christian consciences and worships be granted to all men in all nations and countries: and they are only to be fought against with that sword which is only, in soul matters, able to conquer: to wit, the sword of God's Spirit, the word of God. ${ }^{437}$

Similarly, Hubmaier wrote in on Heretics and Those who

Burn Them,

Yes, it is still no excuse (as they chatter) that they turn the godless over to the worldly power, for those who do this sin even more grievously. John 19. For each Christian has a sword against the wicket, which is the word of God, Eph. 6, but not a sword against the criminal. It is well and good that the secular authority puts to death the criminals who injure the defenceless. Rom. 13. But no one may injure the godless who wishes nothing for himself except to desert the Gospel. ${ }^{438}$

436 Estep, Story, pp. 218-219.

${ }^{43}$ Roger williams, The Bloudy Tenant of Persecution for Cause of Conscience Discussed, ed. E. B. Underhill (London: The Hanserd Knolly's society, 1848), pp. 1-2.

${ }^{438}$ Hubmaier, On Heretics and Those who Burn Them, 1524, in Hubmaier Schriften, pp. $98-99$ 
It is clear that Williams and Hubmaier parallel one another. But it is an open question as to Williams' relationship with continental Anabaptism.

It is without doubt, however, that Anabaptism interacted with English Separatists both in England and on the continent. This alone would be enough to contribute to the idea of religious liberty and freedom of conscience. However, in the greater perspective of the sixteenth and seventeenth centuries, the Anabaptists contributed more than any other group to the idea of religious liberty. From Grebel's separation from Zwingli and the establishment of the Swiss Brethren in Zurich, establishment of the first Anabaptist Church in Zollikon, the evangelism and spread throughout Germany, Moravia, Switzerland, Netherlands, England, and North America, the Anabaptists, through the influence of leaders such as Conrad Grebel, Michael Sattler, and Balthasar Hubmaier, gave the western world its most prized possession -religious liberty, freedom of conscience, and separation of church and state.

Today the Anabaptist heritage is not the sole possession of some inconspicuous "sect" in the backwater of civilization. Rather it is the prized possession of every advanced civilization of the twentieth century world. Where men believe in the freedom of religion, supported by a guarantee of separation of church and state, they have entered into that heritage. Where men have caught the 
Anabaptist vision of discipleship, they have become worthy of that heritage. When corporate discipleship submits itself to the New Testament pattern of the church, the heir has then entered full possession of his legacy. ${ }^{439}$

\section{Conclusion}

In looking at the legacy of the Anabaptists and their contributions to the idea of religious liberty as it is today, it is of great concern that this heritage and legacy be preserved. The purpose of this thesis has been to show that the Anabaptists of the sixteenth century were among the first actively to put into practice the idea of religious liberty, especially its most prominent features, liberty of conscience, and a separated or free church. In doing this the Anabaptists contributed to the idea of separation of church and state as we know it. By their commitment to the christian Gospel and the Reformation's standard, "justification by faith," and the "Priesthood of all Believers," they applied that standard to their view of the church. The ideas that the Anabaptists set in motion and developed through the efforts of leaders like Conrad Grebel, Michael Sattler, and Balthasar Hubmaier became the basis of our modern idea of religious liberty.

${ }^{439}$ Estep, Story, p. 224. 
It is not only the contribution of the Anabaptists to the legacy of freedom that has become the basis of our culture and laws, but, it is hoped, the appreciation of this legacy. This heritage was bought at a price, and that price was their lives. For this reason, freedom not only must be appreciated, it must be preserved. It must be guarded against the dangers that threaten it today. This means that the laws that protect and preserve religious liberty, such as the First Amendment to the Constitution and the other relevant parts of the Bill of Rights, must be protected against the forces that seek to destroy them. It is a positive factor that leaders such as John Whitehead, a top constitutional attorney, who is a specialist in religious liberty and has successfully defended many people whose religious rights have been threatened, and others, are winning the battle for the preservation of religious liberty. However, religious liberty and all freedoms will only be secure when our society returns to the Judeo-Christian absolutes that formed the basis of law in our culture. The present generation must now take its responsibility for the preservation of religious liberty, which demands constant vigilance. . because, as in the words of Hubmaier's motto, truth is immortal. So also is freedom. 


\section{BIBLIOGRAPHY}

Acton, John. History of Freedom and Other Essays. Introduction by John N. Figgis and Reginald V. Laurence, London: Macmillan \& Co., 1907.

Augsburger, Myron S. "Michael Sattler d. 1527 Theologian of the Swiss Brethren Movement." Unpublished dissertation. Richmond: Union Theological Seminary, 1965 .

- Pilgrim Aflame. Scottdale, Pennsylvania: Herald Press, 1977 .

Ball, William. Secularism: Tidal wave of Repression in Freedom and Faith. ed. Lynn R. Buzzard.

Westchester, Illinois: Crossway Books, 1982.

Bates, Searle M. Religious Liberty: An Inquiry. New York: Harper and Brothers, 1945.

Bender, Harold H. Conrad Grebel. Goshen, Indiana: The Mennonite Historical Society, 1950.

Bergsten, Torsten. Balthasar Hubmaier - Anabaptist Theologian and Martyr. ed., W. R. Estep, Jr., Valley Forge, Pennsylvania: Judson Press, 1978.

Blanke, Fritz. Brothers in Christ, The History of the Oldest Anabaptist Congregation, Zollikon near Zurich, Switzerland. Scottdale, Pennsylvania: Herald Press, 1961 .

Cameron, Euan. The Reformation of the Heretics. Oxford: Clarendon press, 1984 .

Carrillo de Albornoz, A. F. The Basis of Religious

Liberty. New York: Association Press, 1963.

Carlyle, Alexander J. The Christian Church and Liberty. London: J. Clarke, 1924. 
Dickens, A. G. The English Reformation. New York: Schocken Books, 1965.

Dillenberger, John, D., ed. Martin Luther - Selections From His Writings. Garden City, New York: Doubleday and Co., Inc., 1961 .

Egli, Emil. Aktensammlung, zur Geschichte der zürcher Reformation in den Jahren 1519-1533. Zürich: Druck von J. Schabelitz, 1879.

Estep, William R. Anabaptist Beginnings 1523-1533. Nieuwkoop: B. deGraff, 1976.

- The Anabaptist Story. Nashville, Tennessee: Broadman Press. 1963.

- "Von Ketzern und Ihren Verbrennern: A Sixteenth Century Tract on Religious Liberty," Mennonite Quarterly Review. October 1969, 271-282.

Fast, Heinold. Heinrich Bullinger und die Täufer. Weierhof, Germany: Mennonitischen Geschichtsverein E.V., 1959 .

Friedmann, Robert. The Theology of Anabaptism. Scottdale, Pennsylvania: Herald Press, 1973.

George, Timothy. "Between Pacifism and Coercion: The English Baptist Doctrine of Religious Toleration," Mennonite Quarterly Review. January, 1984, 30-49.

Gewirth, Alan, ed. Marsilius of Padua, the Defensor Pacis. 2 vols., New York: Columbia University Press, 1956.

Green, John R. A Short History of the English People. New York: A. L. Burt Company, 1874 .

Hinson, E. G. Religious Liberty - The Christian Roots of Our Freedoms. n.p.: Glad River, 1991.

Horst, Irwin B. The Radical Brethren - Anabaptism and the English Reformation to 1558. Niewkoop: B. de Graaf, 1972 . 
Hughes, Paul L., and James F. Larkin. Tudor Royal Proclamations, vol. I: The Early Tudors (1485-1553). New Haven \& London: Yale University Press, 1964.

Jackson, Samuel M. Huldreich Zwingli the Reformer of German Switzerland 1484-1531. New York:

Knickerbocker Press, G. P. Putnam and Sons, 1901. - The Selected Works of Huldreich Zwingli. Philadelphia, Pennsylvania: University of Pennsylvania Press, 1901, reprint 1972.

Jenny, Beatrice. Das Schleitheimer Taufbekenntnis. Thayngen: Karl August in Verlag, 1951.

Jordan, W. K. The Development of Religious Toleration in England. Gloucester, Massachusetts: Peter Smith, 1965, 4 vols.

Klaassen, Walter. "Speaking in Simplicity: Balthasar Hubmaier," Mennonite Quarterly Review. 1966, 139148 .

Latourette, Kenneth S. A History of Christianity, Vol. II: A.D. 1500 - A.D. 1975. New York: Harper \& Row, 1975 .

Lecler, Joseph, S. J. Toleration and the Reformation. 2 vols. New York: Association Press, 1960.

Lindstrom, Carl E. "The Struggle for a Free Church." Thesis, Western Baptist Theological Seminary, n.p., 1948 .

Littell, Franklin H. Origins of Sectarian Protestantism: A study of the Anabaptist View of the Church. New York: Macmillan Company, 1964.

Murray, John Courtney, S. J., ed. Freedom and Man. New York: P. J. Kenedy and Sons, 1965.

Page, William E., ed. The Victoria History of the County of Kent, vol. II. London: St. Catherine Press, 1926 . 
Page, William E., and J. Horace Round, eds. The Victoria History of the county of Essex, vol. II. London: Archibald Constable \& Co., 1907

Pater, Calvin A. Karlstadt as the Father of the Baptist Movements: The Emergence of Lay Protestantism. Toronto: University of Toronto Press, 1984.

Peachey, Shem and Paul Peachey. "Answer of Some who are Called Anabaptists: Why They do not Attend the Churches," Mennonite Quarterly Review. January, $1971,5-32$.

Potter, G. R. Zwingli. Cambridge: Cambridge University Press, $197 \overline{6}$.

Ruffini, Francesco. Religious Liberty. London: Norgate, 1912 .

Ryrie, Charles Caldwell, ed. New American Standard Bible. Chicago: Moody Press, 1978.

Stayer, James M. Anabaptists and the Sword. Lawrence, Kansas: Coronado Press, 1972.

Stephens, W. P. The Theology of Huldreich Zwingli. Oxford: Clarendon Press, 1986.

Strong, Augustus H. Systematic Theology. Valley Forge, Pennsylvania: Judson Press, 1907.

Strype, John. Ecclesiastical Memorials Relating to the Reformation and the Religion and the Reformation of it and the Emergencies of the Church of England, vol. III, pt. 2. Oxford: Clarendon Press, 1820.

Troeltsch, Ernst. The Social Teaching of the Christian Churches. 2 vols., London: G. Allen and Unwin, 1931.

Truett, George w. Baptists and Religious Liberty. Nashville, Tennessee: Southern Baptist Convention, 1920 .

Vedder, Henry C. Balthasar Hubmaier, the Leader of the Anabaptists. New York: G. P. Putnam's and Sons, The Knickerbocker Press, 1905. 
von Muralt, Leonhard, and Walter Schmid, eds. Quellen zur Geschichte der Täufer in der Schweiz. Zürich: S. Hirzel Verlag, Erster Band, 1952.

Yoder, John H. The Legacy of Michael Sattler. Scottdale, Pennsylvania: Herald Press, 1973.

Walton, Robert C., Zwingli's Theocracy. Toronto: University of Toronto Press, 1967.

Weaver, Rufus $w$. Champions of Religious Liberty. Nashville, Tennessee: Southern Baptist Convention, 1945 .

Westin, Gunnar, and Torsten Bergsten. Balthasar Hubmaier Schriften. Gütersloh: Gerd Mohn, 1962.

Whitley, W. T. The Works of John Smyth. 2 vols. Cambridge: Cambridge University Press, 1915.

Williams, G. H. The Radical Reformation, 2nd ed., Sixteenth Century Essays \& Studies. 15, Kirksville, MO: Sixteenth Century Journal Publishers, Inc., 1992 .

Williams, Roger. The Bloudy Tenant of Persecution for Cause of Conscience Discussed 1644. E. B. Underhill, ed. London: The Hanserd Knolly's Society, 1848. 